\title{
EXPOSIÇÃO OCUPACIONAL A SOLVENTES ORGÂNICOS \\ EM TRABALHADORES DE LABORATÓRIOS \\ E EFEITOS GENOTÓXICOS
}

DEOLINDA IZUMIDA MARTINS

Tese de Doutorado apresentada ao

Departamento de Saúde Ambiental da

Faculdade de Saúde Pública da Universidade de São Paulo para obtenção do Grau de Doutor.

Área de concentração:

Saúde Ambiental

ORIENTADOR:

PROF. DR. SÉRGIO COLACIOPPO

São Paulo

2002 
Aos meus pais

Que me deram a vida

Ao Tony
Que me dá a alegria de viver 
"Hoje entendo bem meu pai. Um homem precisa viajar. Por sua conta, não por meio de histórias, imagens, livros ou TV. Precisa viajar por si, com seus olhos e pés, para entender o que é seu. Para um dia plantar as suas proprias árvores e dar-lhes valor. Conhecer o frio para desfrutar do calor. E o oposto. Sentir a distância e o desabrigo para estar bem sob o próprio teto. Um homem precisa viajar para lugares que não conhece para quebrar essa arrogância que nos faz ver o mundo como o imaginamos, e não simplesmente como é ou pode ser; que nos faz professores e doutores do que não vimos, quando deveriamos ser alunos, e simplesmente ir ver."

\author{
Amir Klink \\ Mar Sem Fim
}




\section{AGRADECIMENTOS}

Ao Prof. Dr. Sérgio Colacioppo, pela orientação dada a este trabalho, pela paz e serenidade transmitidas.

À Prof a Dra. Lys Esther Rocha, pelo direcionamento no início deste trabalho e pelas sempre úteis discussões durante o mesmo.

À Prof ${ }^{a}$ Dra Gilka Jorge Fígaro Gattás, Chefe do Departamento de Medicina Legal, Ética Médica e Medicina Social e do Trabalho da FMUSP, por ter permitido a realização de parte deste trabalho no Laboratório de Biologia Molecular deste Departamento, e pelas proveitosas discussões.

À Leni Gomes da Silva e à Maria Salete Siraque, pelo auxílio no desenvolvimento deste trabalho, pelos sábados que estiveram comigo, pelo apoio e carinho.

Às meninas do Laboratório de Biologia Molecular do Departamento de Medicina Legal, Ética Médica e Medicina Social e do Trabalho da FMUSP: Priscila, Luana, Luciana, Gabriela, Maira e Estela, pela inestimável ajuda.

À Fátima Aparecida Diz, Marina Mori Pinto e Maria Salete Siraque, pelas coletas biológicas.

Aos colegas da PerkinElmer do Brasil, pela colaboração, apoio e compreensão.

Às amigas Isarita Martins, Leda Leme Talib, Elisa Ozaki, Vanessa Watase, e aos amigos Antonio Flávio Mídio, Antonio Januzzi e Luiz Augusto Morino, por estarem sempre presentes.

A todos que, direta ou indiretamente, contribuíram para a realização deste trabalho. 


\section{RESUMO}

Martins DI. Exposição Ocupacional a Solventes Orgânicos em Trabalhadores de Laboratórios e Efeitos Genotóxicos. São Paulo; 2002. [Tese de Doutorado - Faculdade de Saúde Pública da USP].

O trabalho em laboratórios químicos, clínicos e toxicológicos, vem sendo relacionado ao desenvolvimento de diversos efeitos nocivos à saúde, incluindo os reprodutivos e de desenvolvimento de tumores. Embora não sejam consideradas como único mecanismo de ação, as alterações genotóxicas decorrentes da exposição a substâncias como solventes em laboratórios estão entre as prováveis causas destes efeitos. A característica da exposição nestes locais, a saber, grande diversidade de compostos a baixas concentrações e baixa freqüência, dificulta a avaliação das exposições e do risco associado a elas. O presente trabalho tem como objetivo estimar a exposição ocupacional a solventes orgânicos em trabalhadores de laboratórios e avaliar danos genotóxicos nos indivíduos expostos. Um grupo exposto composto de 23 trabalhadores de laboratórios e um grupo não-exposto de 22 trabalhadores de escritório foram avaliados. Determinações qualitativas e quantitativas dos solventes nos ambientes dos laboratórios foram realizadas por meio de amostragem passiva, sendo encontrado uma diversidade de solventes em cada amostra analisada (média de 5 solventes por amostra) em concentrações geralmente baixas (Índices de Exposição abaixo de 0,5). Os efeitos genotóxicos foram avaliados por meio do teste citogenético do Micronúcleo (MN) em linfócitos de sangue periférico de 21 indivíduos expostos e 22 indivíduos não-expostos, pareados por idade, gênero e hábito de fumar. Foi utilizado o método do micronúcleo com bloqueio da citocinese por meio de Citocalasina B. A freqüência de $\mathrm{MN}$ foi verificada em 1.000 células binucleadas, sendo encontrada uma diferença significativa nas frequiências de $\mathrm{MN}$ nos trabalhadores de laboratório (4,7 $\mathrm{MN} / 1000$ binucleadas) quando comparada a dos não-expostos (1,9 MN/1000 binucleadas), de acordo com o teste do Qui-quadrado $(\chi 2=28,911 ; 1$ grau de liberdade; $\mathrm{P}<0,0001)$.

Descritores: trabalhador de laboratório, solventes orgânicos, micronúcleo, efeitos genotóxicos 


\section{SUMMARY}

Martins DI. Exposição Ocupacional a Solventes Orgânicos em Trabalhadores de Laboratórios e Efeitos Genotóxicos. [Occupational Exposure to Organic Solvents in Laboratory Workers and Genotoxic Effects]. São Paulo (BR); 2002. [Tese de Doutorado - Faculdade de Saúde Pública da USP].

The relationship between chemical, clinical and toxicological laboratory work and adverse health effects like reproductives outcomes and cancer has been suggested in several epidemiologic reports. The exposure to genotoxic agents like solvents in the laboratory environment could explain in part many of these effects. The assesment of these exposures and the risk associated with them is difficult because the workers are exposed to several chemicals at low concentrations and frequency. The main objective of this study is to estimate the occupational exposure to organic solvents in laboratory workers and evaluate genotoxic damage in exposed individuals. The investigation was carried out on a group of 23 chemical laboratory workers of a reserch center and a group of 22 non-exposed office workers. Solvents concentrations in the laboratory environment were measured and indicated low exposure (Exposure Index $<0,5$ ). Also, a diversity of organic solvents were present in the environmental samples. Genotoxic effects were evaluated using the cytogenetic assay of Cytokinesis-block Micronuclei (MN) in perpherical blood lymphocytes, with aid of cytochalasin B. Blood samples of 21 laboratory workers and 22 referents matched with respect to age, gender and smoking habits were examined. MN frequency was analyzed in 1000 binucleated cells. There was significant increase in cells with micronuclei $(\mathrm{P}<0,0001)$ in laboratory workers $(4.7$ $\mathrm{MN} / 1,000$ cells) in comparison to the matched controls ( $1.9 \mathrm{MN} / 1,000$ cells).

Descriptors: laboratory workers, organic solvents, micronuclei, genotoxic effects 


\section{ÍNDICE}

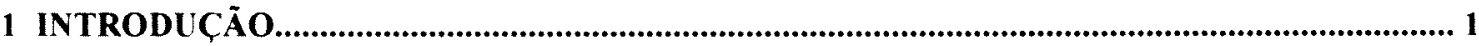

1.1 EFEITOS REPRODUTIVOS EM TRABALHADORES DE LABORATÓRIOS .................................. 4

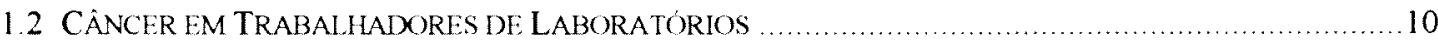

1.3 GENOTOXICIDADE E AVALIAÇȦO DA EXPOSIÇÃO A AGENTES GENOTÓXICOS ........................11

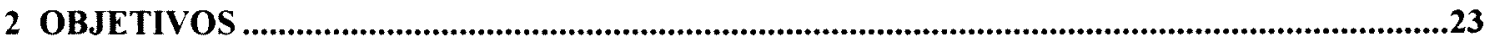

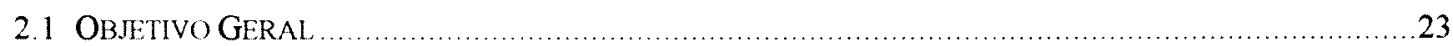

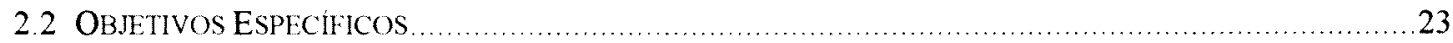

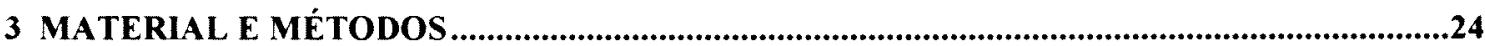

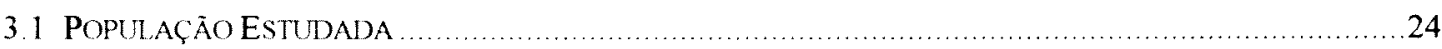

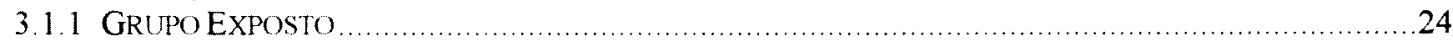

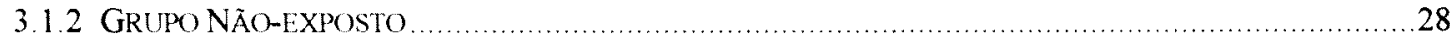

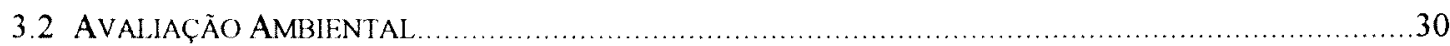

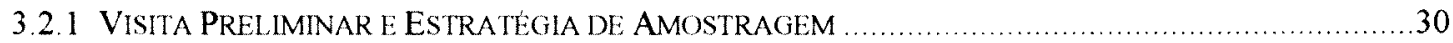

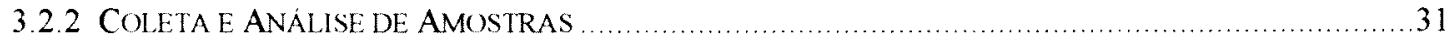

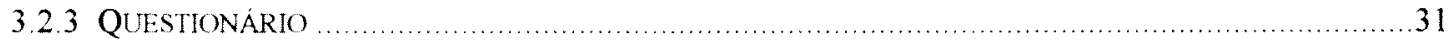

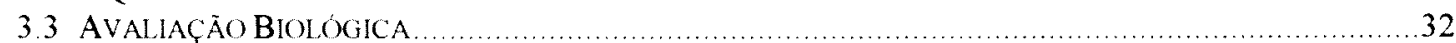

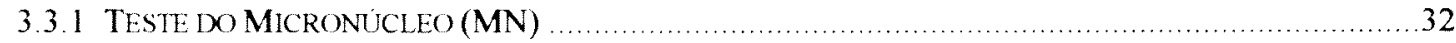

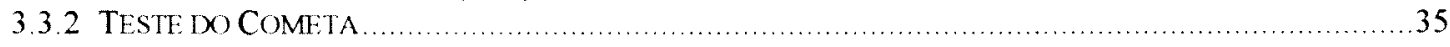

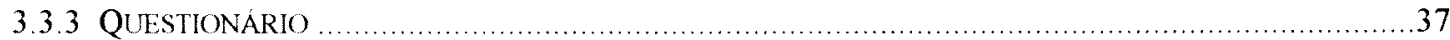

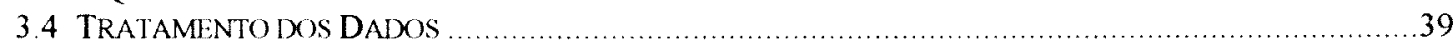

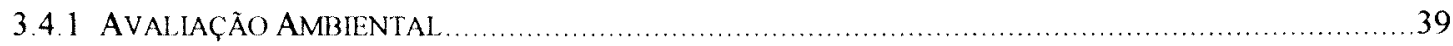

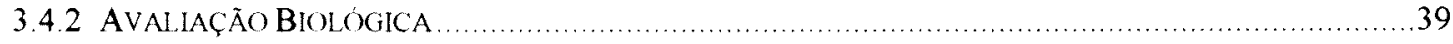

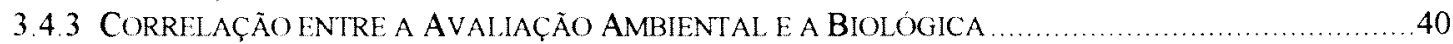

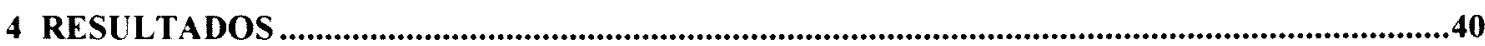

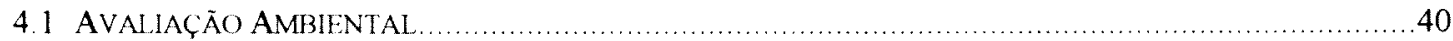

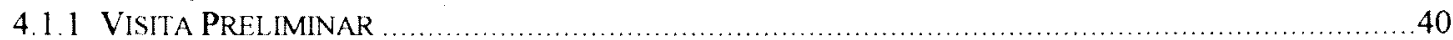

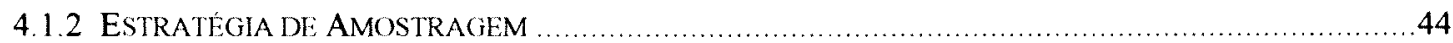

4.1.3 EstIMATIVA QUALITATIVA E QUANTITATIVA DA EXPOSIÇÃO ..........................................46

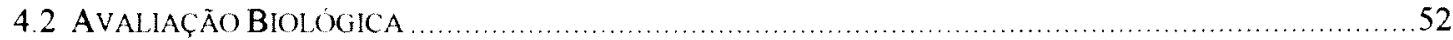

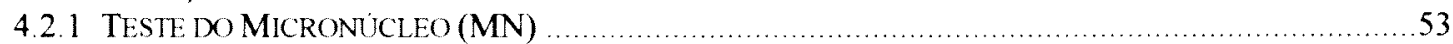

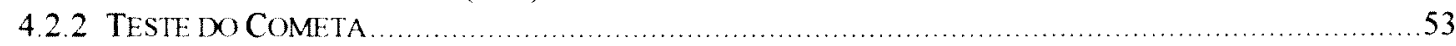

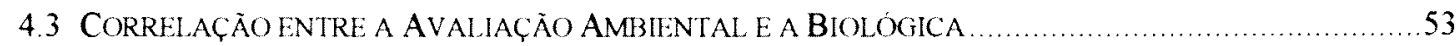

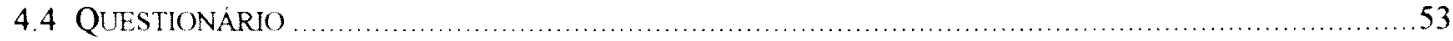

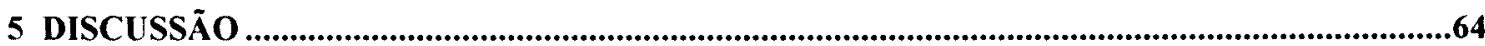

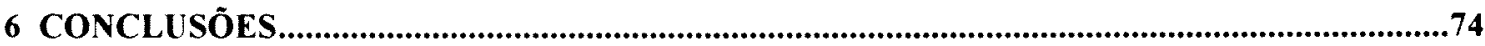

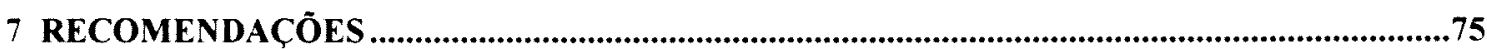

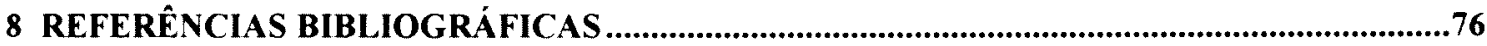

ANEXO I-Avaliação do Projeto de Tese de Doutorado pelo COEP da FSP-USP.................... A-1

ANEXO II- Termo de Consentimento Pós-Informado - Grupo Exposto ..................................... A-3

ANEXO III- Termo de Consentimento Pós-Informado - Grupo Não-exposto .......................... A-6

ANEXO IV- Ficha de Coleta - Análise Ambiental ................................................... A-9

ANEXO V- Questionário - Avaliação Ambiental ......................................................... A-11

ANEXO VI- Questionário - Avaliação Biologica ......................................................... A-16 


\section{INTRODUÇÃO}

Laboratórios podem ser definidos de forma metafórica como "teatros de notáveis operações ou transformações" ou de forma mais realística como "locais destinados ao estudo experimental de qualquer ramo da ciência ou à aplicação dos conhecimentos científicos com objetivos práticos”. Tomando por base esta última definição, podemos inferir que trabalhadores de laboratórios exercem atividades as mais variadas relacionadas à pesquisa científica e/ou às suas aplicações e estão presentes nas áreas de pesquisas (universidades, centros de pesquisa), de serviços (laboratórios químicos, toxicológicos, clínicos, biomédicos, etc.), bem como nos diversos segmentos da indústria (química, farmacêutica, petroquímica, etc.).

Assim como qualquer ambiente ocupacional, os laboratórios apresentam riscos à saúde dos trabalhadores, neste caso, principalmente devido à presença de agentes químicos, físicos e biológicos (OLIN 1978; BUESCHING et al. 1989).

Efeitos sobre a saúde reprodutiva e o desenvolvimento de tumores estão entre os principais riscos associados ao trabalho em laboratórios. Exposições a vírus, bactérias (agentes biológicos), substâncias radioativas (agentes físicos) e principalmente a diversos compostos químicos são considerados os principais fatores de risco nestes ambientes.

O grupo dos solventes orgânicos é o mais implicado nos estudos que investigam efeitos reprodutivos e câncer em trabalhadores de laboratórios (TASKINEN et al. 1994; BURNETT et al. 1999; WENNBORG et al. 2000; WENNBORG et al. 2001 A; WENNBORG et al. 2001 B; WENNBORG et al 2002). Outros compostos citados são metais, corantes (azocompostos, derivados da benzidina e orto-toluidina) e pesticidas (HEIDAM 1984; BABICH 1985).

Dificuldades normalmente são encontradas nas tentativas de se estabelecer uma relação de causalidade entre as exposições ocupacionais a solventes nos 
laboratórios e os efeitos reprodutivos e carcinogênicos, uma vez se tratarem de efeitos raros e decorrentes de exposições a baixas concentrações dos compostos.

As contradições e inconsistências observadas nestes estudos são decorrentes principalmente da falta de exatidão das avaliações ambientais, da ausência de biomarcadores adequados e do pouco conhecimento a respeito dos mecanismos de ação tóxica que explicam tais efeitos, assim como da relação dose-resposta para os mesmos (WINDHAM et al. 1991; LINDBOHM 1999).

Há que se considerar como fatores complicadores, em primeiro lugar, a característica das exposições a solventes nos laboratórios, ou seja, uma diversidade de compostos presentes em baixas concentrações e, geralmente, de forma infreqüente (IARC 1979) e, do ponto de vista da toxicologia, a dificuldade de previsão de interações aditivas, sinérgicas ou de potenciação, que podem surgir em situações de exposições a misturas de substâncias químicas (SNYDER e ANDREWS 1996).

Tudo isso se reflete na incerteza da segurança das exposições atuais ocorridas em laboratórios, quanto aos possíveis efeitos à saúde dos indivíduos expostos, considerando que neste caso, somente as boas práticas de laboratório podem não ser suficientes para evitar o risco de desenvolvimento dos efeitos aqui considerados.

O uso de questionários e entrevistas auto-reportados é a forma mais comum de avaliação das exposições ocupacionais nos estudos epidemiológicos, uma vez que a maior parte deles tem desenho retrospectivo. Assim, as avaliações podem ser superestimadas ou subestimadas, sendo o último caso o maior problema (LINDBOHM 1999).

A necessidade de medidas mais objetivas das exposições, assim como o uso de biomarcadores, vem sendo sugerida para que os estudos sejam validados (LIPSCOMB et al. 1991). Alguns estudos recentes têm incluído, além dos questionários auto-reportados, avaliações realizadas por higienistas ocupacionais (TASKINEN et al. 1994; SALLMÉN et al. 1995). 
A avaliação biológica da exposição a agentes genotóxicos pode ser feita utilizando-se indicadores de exposição ou de efeito (LOHMAN et al. 1984; AITIO 1994).

A avaliação realizada através dos indicadores de exposição utiliza as determinações dos agentes e/ou de seus produtos de biotransformação em algum material biológico (sangue, urina, ar exalado), ou ainda os aductos de macromoléculas (DNA ou proteínas), estes últimos conhecidos como indicadores de dose biologicamente efetiva.

Para a determinação dos indicadores de efeito são considerados efeitos ainda não-nocivos e incluem principalmente as aberrações cromossômicas, troca de cromátides irmãs e micronúcleo, determinados através de testes citogenéticos.

Vantagens e desvantagens são vistas em ambos os tipos de indicadores, de exposição e de efeito (AITIO 1994). No caso específico dos testes citogenéticos utilizados como indicadores de efeito, algumas dificuldades apontadas são: o longo tempo gasto na análise, a necessidade de um grupo controle e a falta de validação para avaliar quantitativamente as exposições.

A necessidade de técnicas analíticas sofisticadas e dispendiosas e a falta de validação da relação entre exposição e efeito constituem limitações para os indicadores de dose biologicamente efetiva (aductos de macromoléculas).

Especificidade constitui a principal vantagem dos indicadores de exposição que utilizam as determinações das concentrações dos próprios solventes e/ou de seus produtos de biotransformação. Por outro lado, neste caso particular do ambiente de laboratórios onde são encontrados diversos solventes ao mesmo tempo, uma dificuldade surge devido a esta especificidade, uma vez que seria necessário determinar pelo menos um indicador para cada solvente presente, resultando num número excessivo de determinações. 


\subsection{Efeitos Reprodutivos em Trabalhadores de Laboratórios}

Os principais efeitos sobre a saúde reprodutiva associados a exposições ocupacionais a agentes químicos incluem: redução da fertilidade, abortos espontâneos, malformações congênitas, além de câncer/leucemia e outras doenças na infância (WHO 1985; CORDIER et al. 1994).

As exposições ocupacionais a solventes vêm sendo relacionadas com o aparecimento de casos de abortos espontâneos e malformações desde a década de 80 (WENNBORG et al. 2000).

Um maior risco de malformações tem sido observado em crianças nascidas de mulheres que trabalham em diferentes tipos de laboratórios, conforme revisado por CORDIER e GOUJARD (1994) e mostrado na Tabela 1.1. Uma revisão dos estudos que avaliaram exposições a solventes e anomalias congênitas e abortos espontâneos também foi realizada no trabalho desses autores.

TASKINEN et al. (1994) estudaram a relação entre abortos espontâneos, malformações congênitas, peso ao nascer e trabalho em laboratórios de pesquisa na Finlândia, através de um estudo caso-controle retrospectivo. Os resultados mostraram uma associação significante entre abortos espontâneos e exposição a tolueno (razão de chances $=4,7 ; I^{*} 95 \%, 1,4-15,9$ ) e xilenos (razão de chances $=3,1 ;$ IC 95\%, 1,3-7,5) por 3 vezes ou mais na semana. Não foram encontradas associações para os demais efeitos estudados.

Em um estudo realizado com trabalhadoras de laboratórios de pesquisa biomédica na Suécia para avaliação de efeitos reprodutivos, foi observada uma razão de chances de abortos espontâneos elevada para o trabalho com clorofórmio (razão de chances $=2,3$; IC 95\%, 0,9-5,9), embora não tenha sido elevada para o trabalho de laboratório em geral (WENNBORG et al. 2000).

* IC = Intervalo de Confiança. 
Outros estudos, porém, têm falhado em demonstrar um maior risco de abortos espontâneos (HEIDAM 1984) ou malformações (LINDBOHM 1995) entre trabalhadoras de laboratórios.

HEIDAM (1984) conduziu uma investigação envolvendo 445 trabalhadores de laboratórios de hospitais, indústrias e universidades e 1.431 trabalhadores referência (de escritório, fisioterapeutas, terapeutas ocupacionais, desenhistas) com o objetivo de avaliar um aumento do risco de abortos espontâneos nos trabalhadores de laboratórios. As informações foram obtidas através de questionários. Nenhum aumento significativo nas razões de chances para abortos espontâneos foi observado para a ocupação ou exposições informadas nos questionários. De acordo com o autor, os resultados são conflitantes com outros estudos e poderiam ser explicados pelos diferentes grau e natureza das exposições nos vários laboratórios investigados e o uso de populações selecionadas em alguns estudos. 
$\circ$

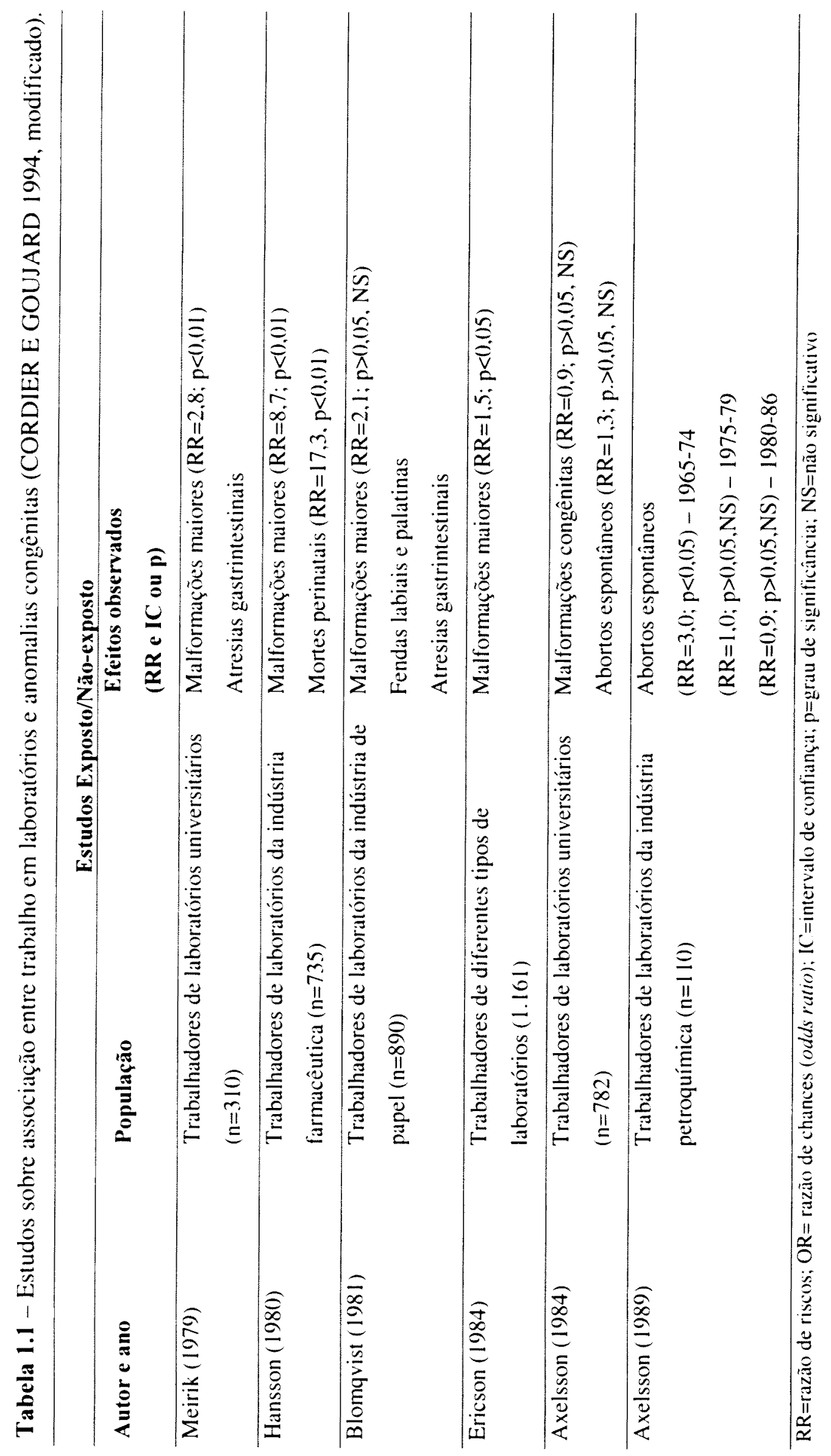




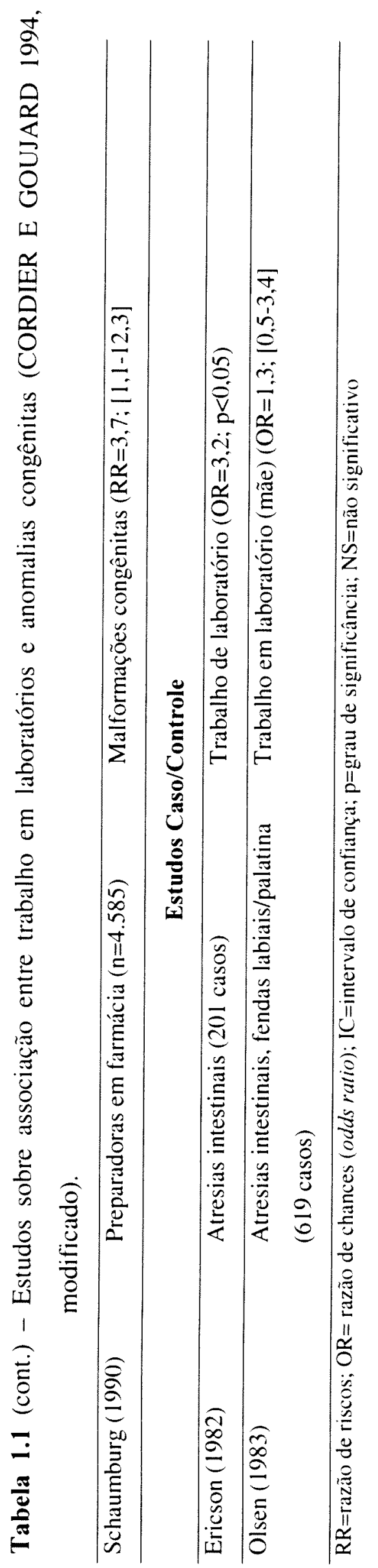


Com o objetivo de investigar possíveis efeitos da exposição a solventes e outros fatores de risco presentes em laboratórios sobre a fertilidade, WENNBORG et al. (2001) conduziram um estudo envolvendo 560 mulheres e 735 gestações durante o período de 1990-1994. Mulheres trabalhando em laboratórios (grupo exposto) contribuíram com 411 gestações e as que não trabalhavam em laboratórios (grupo controle) com as demais 324 gestações. A fertilidade foi estimada através do tempo (ciclos) necessário para engravidar e a avaliação realizada através do cálculo de razão de fertilidade (RF) entre o grupo exposto e o grupo controle. As informações a respeito das exposições a solventes foram obtidas através de questionário. Uma redução da razão de fertilidade foi observada para trabalho com solventes orgânicos em geral $(\mathrm{RF}=0,79$, IC 95\%, 0,68-0,93) e especificamente para trabalho com acetona $(\mathrm{RF}=0,72$, IC 95\%, 0,53-0,97). Outros solventes avaliados , porém, com resultados negativos, foram benzeno, clorofórmio e éter dietílico.

Em um estudo retrospectivo realizado com a finalidade de verificar os efeitos da exposição a solventes sobre a fertilidade, a exposição foi avaliada com base na descrição com base na descrição do trabalho feita pelo próprio trabalhador e através de medidas biológicas da exposição. Os resultados indicaram um prolongado tempo para gestação entre as mulheres com exposições altas ou diárias a solventes (SALMMÉN et al. 1995).

Outros efeitos reprodutivos vem sendo estudados recentemente. WENNBORG et al. (2002) avaliaram nascimentos pré e pós-termo e peso ao nascer em 249 mulheres que estavam trabalhando em laboratórios durante a gestação e 613 mulheres que não trabalhavam em laboratórios (controles). Informações a respeito da exposição a vários agentes químicos, físicos e microbiológicos foram coletadas a partir de um questionário. Os resultados indicaram um maior risco de nascimentos pré-termo (idade gestacional menor que 37 semanas) para as mulheres que trabalhavam em laboratórios executando tarefas que envolviam solventes (razão de chances $=3,4$, IC $95 \%, 1,0-11,9)$.

Uma redução de 155 gramas (IC 95\%, -356 a 46) no peso ao nascer (nascimentos a termo) foi observada em gestações de 22 trabalhadoras de 
laboratórios expostas a éter dietílico. O mesmo efeito não foi observado para os outros solventes avaliados neste estudo: acetona, clorofórmio, tolueno e fenol (WENNBORG et al. 2000).

Embora seja difícil implicar solventes específicos nestes estudos, devido a própria característica das exposições, alguns deles têm sido mais comumente relacionados, como por exemplo, tolueno, xilenos, clorofórmio e alguns do grupo dos alifáticos (TASKINEN et al. 1994; LINDBOHM 1995; WENNBORG et al. 2000).

Além das exposições ocupacionais de mulheres a solventes, exposições de homens são também consideradas nas avaliações de riscos reprodutivos (TASKINEN et al. 1989; LINDBOHM et al. 1991; CORDIER e GOUJARD 1994), embora as evidências dos efeitos sejam menos consistentes (LINDBOHM 1995).

A exposição ocupacional paterna a solventes (estireno, tolueno, xilenos, tetracloretileno, tricloretileno e 1,1,1-tricloretano) foi associada a um maior risco de abortos espontâneos ( $\mathrm{OR}=2,3 ;[1,1-5,9])$, conforme estudado por TASKINEN et al. (1989). Em outro estudo, OLSEN et al. (1983) avaliaram 83 casos de anomalias congênitas do SNC e exposições paternas a solventes, observando uma associação significativa entre eles $(\mathrm{OR}=2,8 ;[0,8-9,4])$.

LINDBOHM et al. (1991) avaliaram o efeito das exposições ocupacionais paternas sobre o risco de abortos espontâneos em 99.186 gestações na Finlândia no período de 1975-80. Informações a respeito da ocupação foram obtidas através do Censo e uma classificação ocupação-exposição foi desenvolvida por higienistas para determinar as exposições ocupacionais. A razão de chances de abortos espontâneos foi significativamente maior para exposição paterna a solventes usados em refinarias de petróleo $(\mathrm{OR}=2,2$; IC 95\%, 1,3-3,8) e solventes usados na produção de borracha $(\mathrm{OR}=1,9 ; \mathrm{IC} 95 \%, 1,2-2,8)$.

Em um estudo de caso descrito por CHANG et al. (2001), um trabalhador de laboratório exposto a clorofórmio em concentrações 10-50 vezes maior do que os limites de exposição permissíveis (limites para 2h/dia, 5,5 dias/semana, 4,25 
semanas-mês/8 meses) desenvolveu astenospermia e problemas de fertilidade. A suspeita de que estes efeitos reprodutivos estavam relacionados à exposição ao clorofórmio foi reforçada pela conhecida ação espermatotóxica deste solvente.

Estudos que tentam estabelecer uma associação entre exposição ocupacional de pais a agentes químicos e risco de câncer nos descendentes foram revisados por O'LEARY et al. (1991). Exposições a solventes, especialmente hidrocarbonetos clorados como tricloretileno, além de benzeno e metil-etil-cetona, foram associados com maior risco de leucemia ou tumor cerebral em filhos de pais expostos ocupacionalmente.

\subsection{Câncer em Trabalhadores de Laboratórios}

A mortalidade por câncer entre trabalhadores de laboratórios vem sendo estudada, porém, os estudos são poucos e os resultados ainda inconsistentes. Entre os tipos de câncer encontrados elevados nestas populações estão câncer de mama, pâncreas, cérebro e linfoma não-Hodgkin (CORDIER 1990; CARPENTER et al. 1991; BROW et al. 1996, RACHET et al. 2000).

BURNETT et al. (1999) estudaram o risco de mortalidade por câncer em técnicos de laboratórios clínicos e de pesquisas química e biológica, encontrando um excesso de casos de câncer linfático e hematopoiético nestes trabalhadores, o que, segundo os mesmos autores, poderia estar relacionado às exposições químicas no ambiente de trabalho, incluindo benzeno e outros solventes.

Com o objetivo de elucidar a ocorrência de câncer em trabalhadores de laboratórios de pesquisa na Suécia com exposições específicas a agentes químicos, físicos e biológicos, WENNBORG et al. (2001) acompanharam uma coorte de 1970 a 1994, composta de 3.277 trabalhadores de laboratórios e 2.011 trabalhadores referência. Os resultados mostraram elevadas razões de incidência padronizadas (SIRs-standardized incidence ratios) para melanoma maligno em mulheres empregadas em laboratórios expostas a solventes orgânicos $(\mathrm{SIR}=2,73$; IC 
1,10-5,63) e um leve aumento para câncer de mama ( $\operatorname{SIR}=1,13$; IC 0,66-1,81). Os solventes mais comumente utilizados nestes laboratórios foram: benzeno, tricloretileno, tetracloretileno, clorofórmio, tetracloreto de carbono, diclorometano, 1,2-dicloroetano.

Em estudos anteriores, WENNBORG et al. (1999) observaram um leve aumento das razões de incidência padronizadas para tumores de cérebro entre trabalhadores de laboratórios homens e para câncer de mama entre cientistas mulheres.

Outros estudos demostraram um excesso de tumores de cérebro (BELLI et al. 1992; CORDIER et al. 1995; DALY et al. 1994), tumores de mama ((DOSEMECI et al. 1992; BELLI et al. 1992) tumores linfo-hematopoiético (GUSTAVSSON et al. 1999; BELLI et al. 1992) e tumores de pâncreas (BELLI et al. 1992; CORDIER et al. 1995) em trabalhadores de laboratórios de patologia, química clínica, genética, etc.

As exposições a solventes orgânicos em diversas ocupações têm sido relacionadas com o desenvolvimento de tumores malignos em diversos sítios, a saber, sistemas linfático e hematopoiético (MILIGI et al. 1999; LAZAROV et al. 2000), mama (HANSEN 1999; BAND et al. 2000), pâncreas (OJAJARVI et al. 2000) rins (PESCH et al. 2000), entre outros.

\subsection{Genotoxicidade e Avaliação da Exposição a Agentes Genotóxicos}

Genotoxicidade de compostos químicos é uma característica química intrínsica baseada no potencial eletrofílico destes agentes de ligação com sítios nucleofílicos das macromoléculas celulares como ácido desoxirribonucleico (DNA), portador da informação hereditária (SORSA 2000). Assim, o potencial genotóxico de uma substância química corresponde à sua capacidade de produzir dano ao material genético de células germinativas e/ou somáticas. 
A genotoxicidade inclui ambas ações diretas e indiretas no DNA,

a saber:

- indução de mutações;

- eventos indiretos associados com mutagênese (aberrações cromossômicas, troca de cromátides irmãs, micronúcleo);

- danos no DNA (formação de aductos) que podem eventualmente conduzir a mutações.

A manifestação destas ações em células germinativas pode conduzir à infertilidade, abortos espontâneos, malformações congênitas e doenças hereditárias; enquanto que em células somáticas pode dar origem ao processo de iniciação de tumores malignos (WHO 1985).

Mutações são alterações hereditárias permanentes nas linhagens de células, podendo assim afetar o próprio organismo através de alterações nas suas células ou serem transmitidas para outras gerações através da alteração das células germinativas. Portanto, a genotoxicidade precede a mutagenicidade, embora a genotoxicidade geralmente é reparada e nem sempre se expressa como mutação (SORSA 2000).

Diferentes mecanismos de ação podem estar envolvidos no espectro de efeitos reprodutivos, desde alterações no sistema endócrino, passando por embriotoxicidade, fetotoxicidade e aleitamento, chegando nas alterações genotóxicas (CORDIER e GOUJARD 1994).

Similarmente, os efeitos carcinogênicos são explicados em parte pela ação genotóxica dos compostos, podendo outros mecanismos estarem envolvidos, como por exemplo, os epigenéticos: promoção e progressão (PITOT e DRAGAN 1996).

A relação entre genotoxicidade e efeitos reprodutivos e câncer é resumida na Figura 1.1. 


\section{GENOTOXICIDADE}

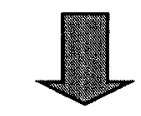

- Mutações

- Danos visíveis microscopicamente

(aberrações cromossômicas, micronúcleo, etc.)

- Aductos de DNA
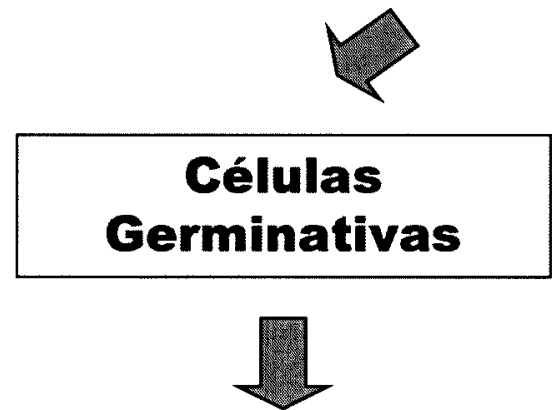

Efeitos

Reprodutivos

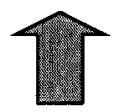

- Alterações sistema endócrino

- Embriotoxicidade

- Fetotoxicidade
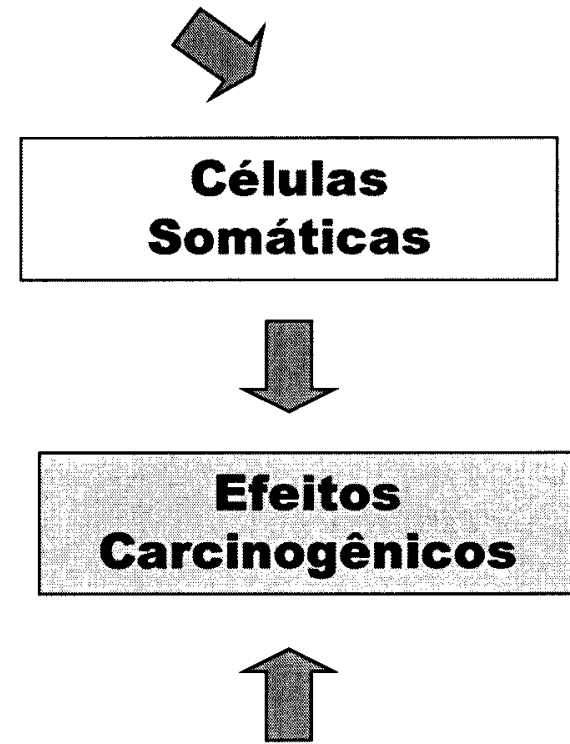

- Mecanismos epigenéticos

Figura 1.1 - Genotoxicidade e outras causas de efeitos reprodutivos e carcinogênicos. 
Indicadores de exposição (dose interna), de dose biologicamente efetiva, e de efeito são disponíveis para a avaliação biológica da exposição a agentes genotóxicos (LOHMAN et al. 1984; AITIO 1994).

Para a determinação dos indicadores de exposição, alguns métodos são seletivos, como a determinação do agente tóxico e/ou seu produto de biotransformação em algum material biológico. Também entre os métodos seletivos estão as determinações de aductos de macromoléculas, onde a dose do agente genotóxico é medida na molécula alvo - DNA ou proteínas (dose biologicamente efetiva), mas não necessariamente na célula alvo, de qualquer forma, refletiria melhor o risco à saúde do que no primeiro caso.

Ainda dentro da monitorização biológica de exposição encontram-se os métodos não-seletivos, como a dosagem de tioéteres na urina e a avaliação da mutagenicidade na urina. A falta de especificidade, juntamente com outros problemas como recuperação variável para os tioéteres e baixa concentração ou presença na forma inativa de alguns agentes mutagênicos na urina, são algumas das desvantagens destes tipos de avaliações.

Testes citogenéticos têm sido propostos na monitorização biológica de efeito de compostos genotóxicos. Estes, medem as alterações genotóxicas produzidas por estes agentes e incluem principalmente as aberrações cromossômicas, troca de cromátides irmãs e micronúcleo.

Uma avaliação dos métodos acima e de outros utilizados na monitorização da exposição a agentes químicos genotóxicos foi realizada por LOHMAN et al. (1984) e é resumida na Tabela 1.2. Nesta tabela, uma série de características que determinam um bom Indicador Biológico são avaliadas para os diversos métodos disponíveis. O Indicador Biológico ideal avalia o efeito à saúde além da exposição, permite a interpretação com base individual além de grupo, é preciso, sensível, específico, possui metodologia de análise simples, possibilita fácil armazenamento da amostra e deve permitir o uso em rotina para que possa ser aplicado na monitorização biológica. Uma breve observação da tabela nos mostra que não há um 
único Indicador Biológico ideal e que, portanto, ou o ideal seria a utilização de mais de um indicador ou, no caso da impossibilidade de utilização de vários indicadores, a escolha seria determinada de acordo com os objetivos principais da avaliação. Além disso, a observação da tabela nos aponta uma incerteza em vários dos aspectos avaliados para os indicadores, revelando a necessidade de mais estudos que possam mostrar caminhos mais seguros na utilização dos mesmos. Alguns destes estudos já evoluiram considerando que a tabela foi compilada em 1984.

Nas técnicas citogenéticas propostas para a monitorização biológica, as aberrações cromossômicas, embora não específicas para um único agente, são consideradas específicas para efeito clastogênico total de uma mistura de agentes químicos. Por outro lado, a análise é considerada subjetiva, tediosa, requer grande habilidade e consume tempo do analista. Recentemente, o desenvolvimento de programas de computador têm solucionado em parte estas dificuldades.

A análise de troca de cromátides irmãs (TCI) requer menos habilidades e consome menor tempo. Porém, a base biológica deste fenômeno não é bem compreendido e tem sido verificada uma influência das condições da cultura de células sobre a frequiência de TCI.

A análise de micronúcleos vem sendo estudada mais recentemente com indícios de aplicações mesmo em rotinas (AITIO 1994).

Micronúcleo pode ser definido (RIEGER et al. 1968) como "um núcleo separado e adicional ao núcleo principal, produzido durante a telófase da mitose ou meiose por cromossomos que se atrasam ou por fragmentos de cromossomos derivados de alterações cromossômicas estruturais induzidas espontaneamente ou experimentalmente" (Figura 1.2).

O teste do micronúcleo consiste na contagem do número e freqüência de micronúcleos em um total de células (centenas ou milhares) utilizando a técnica de microscopia óptica. 
As primeiras aplicações do teste do micronúcleo se deram nas décadas de trinta e quarenta em diversos materiais, principalmente plantas tratadas com radioações ionizantes. Estes estudos foram estimulados fundamentalmente pelas consequiências da bomba atômica na Segunda Guerra Mundial, assim como pelo uso das radiações ionizantes na terapia do câncer (EVANS 1997). 


\begin{tabular}{|c|c|c|c|c|c|c|c|}
\hline 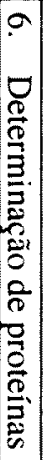 & 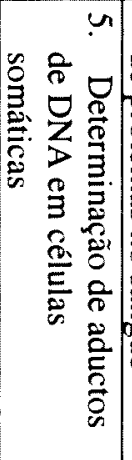 & 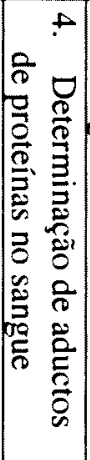 & 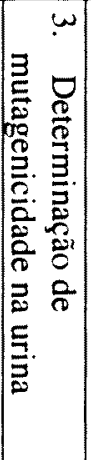 & 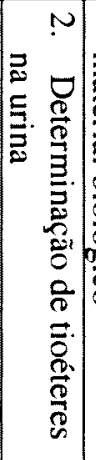 & 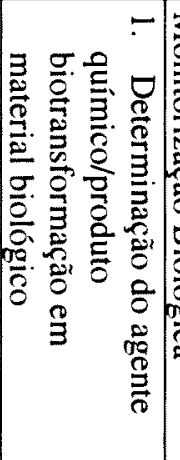 & 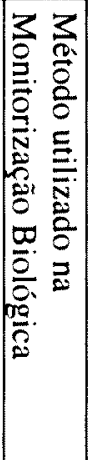 & \\
\hline & & & & & & & \multirow{8}{*}{$\begin{array}{l}\text { Adequado para avaliação da exposição } \\
\text { - qualitativa } \\
\text { - recente (<1 semana) - dose interna } \\
\text { - carga corpórea - longo prazo } \\
\text { - dose no sítio alvo } \\
\text { Adequado para avaliação de efeito à } \\
\text { saúde } \\
\text { - não-adverso (reversível) } \\
\text { - adverso }\end{array}$} \\
\hline \pm & + & + & + & + & + & & \\
\hline ث. & 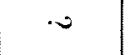 & + & \pm & I & + & & \\
\hline ' &.$\diamond$ & $t_{\approx}$ & ' & ' & $1+$ & & \\
\hline , & + & $t_{\sigma}$ & ' & 1 & ' & & \\
\hline & & & & & & & \\
\hline ث. & $\diamond$ & \pm & . & , & $1+$ & & \\
\hline. & $\bullet$ & I & . & ' & $1+$ & & \\
\hline & & & & & & & \multirow{3}{*}{$\begin{array}{l}\text { Interpretação do resultado } \\
\text { - base individual } \\
\text { - base de grupo }\end{array}$} \\
\hline . & \pm & + & . & ' & $1+$ & & \\
\hline 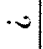 & + & + & + & + & H+ & & \\
\hline & & & & & & & \multirow{4}{*}{$\begin{array}{l}\text { Precisão do método } \\
\text { - reprodutibilidade técnica } \\
\text { - estabilidade do parâmetro no tempo } \\
\text { - reprodutibilidade interlaboratorial }\end{array}$} \\
\hline. & $\cdot$ & ט. & \pm & $\mp$ & + & & \\
\hline .0 & $\omega$ & .0 & ' & ' & H+ & & \\
\hline . & 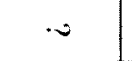 & ث. & $I$ & $I$ & + & & \\
\hline & & & & & & & \multirow{4}{*}{$\begin{array}{l}\text { Sensibilidade } \\
\text { - para exposições ambientais } \\
\text { - para exposições ocupacionais } \\
\text { - para exposições agudas }\end{array}$} \\
\hline ' & \pm & ' & It & 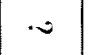 & + & & \\
\hline+ & + & + & + & 0 & + & & \\
\hline+ & + & + & + & 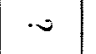 & + & & \\
\hline ' & + & + & ' & ' & + & & Especificidade química \\
\hline 1 & $\mp$ & $\cdot$ & ' & ' & + & & Ausência de interferentes \\
\hline . & I &. & ' & ' & 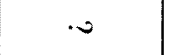 & & Ausência de níveis de background \\
\hline ' & 1 & ' & ' & ' & + & & Simplicidade de análise \\
\hline ' & + & + & + & + & $1+$ & & $\begin{array}{l}\text { Possibilidade de fácil armazenamento da } \\
\text { amostra. }\end{array}$ \\
\hline & & & & & & & \multirow{3}{*}{$\begin{array}{l}\text { Aplicabilidade atual } \\
\text { - nível pesquisa } \\
\text { - uso em rotina }\end{array}$} \\
\hline+ & + & + & + & + & + & & \\
\hline ' & 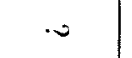 & I & $\cdot$ & 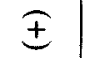 & + & & \\
\hline
\end{tabular}




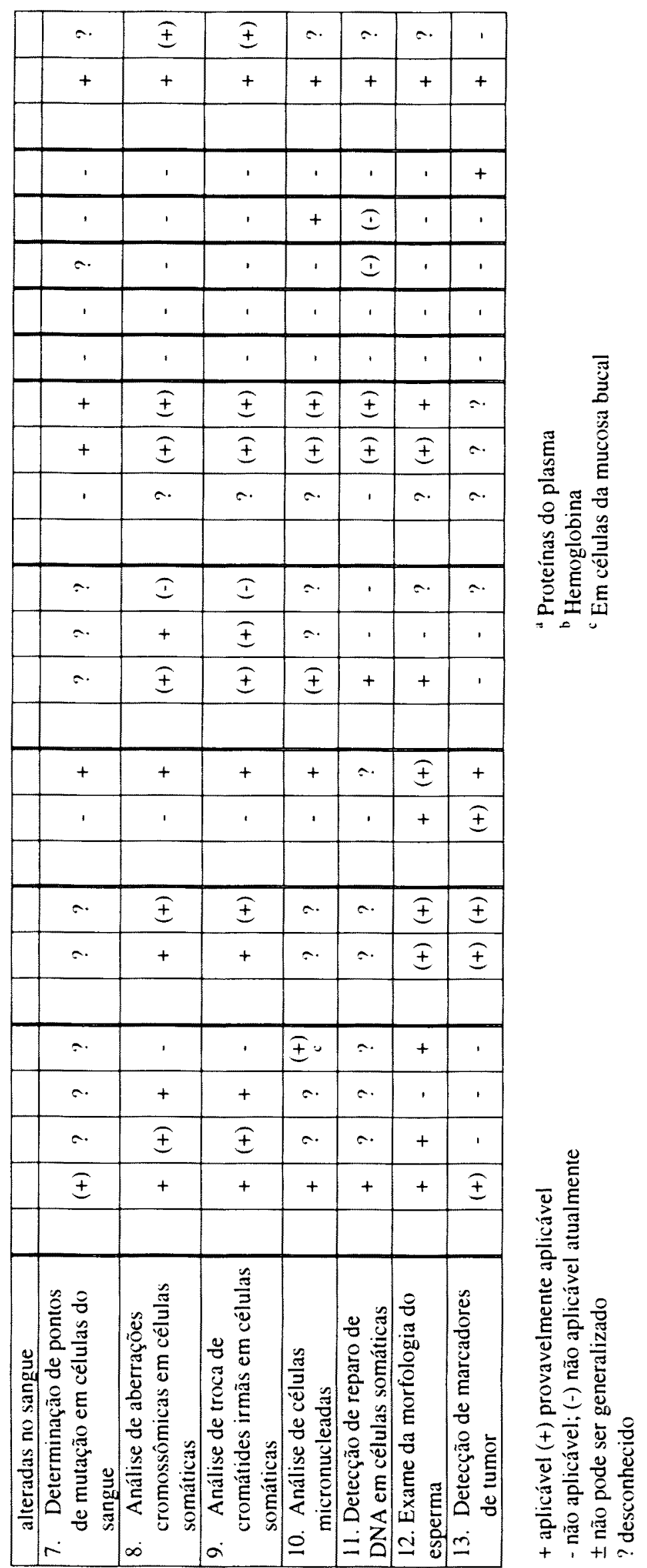




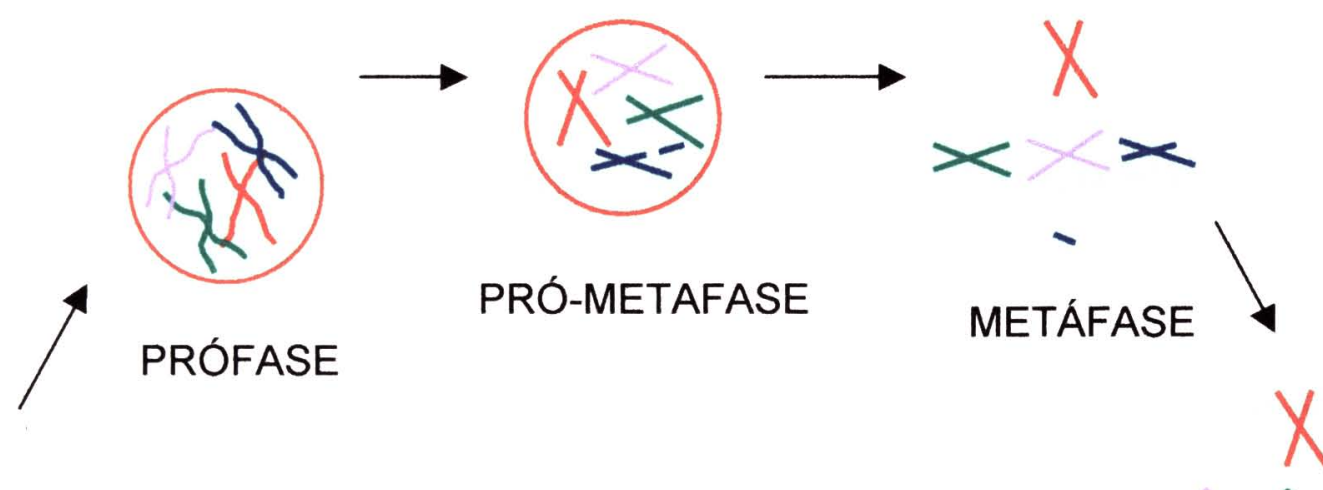

(A)

(B)

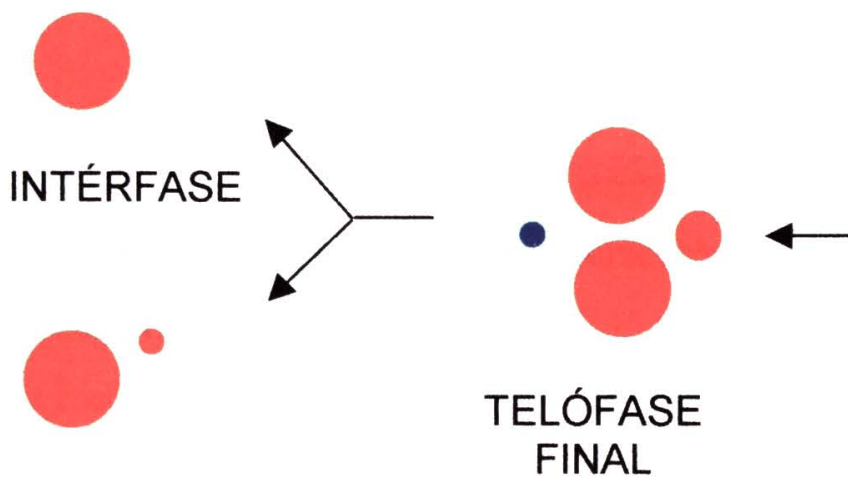

TELÓFASE INICIAL

Figura 1.2 - Representação esquemática da formação de micronúcleo.

$\mathrm{O}$ uso do teste do micronúcleo como uma medida de dano cromossômico em linfócitos de sangue periférico foi proposto por COUNTRYMAN e HEDDLE (1976). Porém, se por um lado a produção de micronúcleos depende de uma mitose completa, por outro lado, os linfócitos não respondem a um estímulo mitogênico de forma homogênea. Como conseqüência, uma variação na freqüência da proliferação de linfócitos afetava a contagem de micronúcleos (MÜLLER et al. 1996). Este problema foi solucionado por FENECH e MORLEY (1985a,b), que introduziram o método do micronúcleo com bloqueio da citocinese. Neste último, a adição de Citocalasina $\mathrm{B}$ permite a divisão do núcleo (cariocinese), mas não da 
célula, resultando em células binucleadas, nas quais (e somente nestas) os micronúcleos são contados.

A partir de então, o teste do micronúcleo com bloqueio da citocinese passou a ser extensivamente utilizado para avaliar a presença e intensidade de dano cromossômico em populações expostas a agentes genotóxicos em várias ocupações, no ambiente, ou como consequiência de estilos de vida (BONASSI et al. 2001).

A ampla utilização deste ensaio pode ser atribuída a duas principais razões (BONASSI et al. 2001):

- o teste do micronúcleo em linfócitos de sangue periférico fornece uma medida confiável de quebra e perda cromossômica, a um baixo custo e com menor trabalho que as aberrações cromossômicas;

- a recente técnica do micronúcleo com bloqueio de citocinese eliminou a confusão causada pelos efeitos da cinética da divisão celular.

Trabalhadores de um laboratório de pesquisa no Canadá expostos rotineiramente a solventes orgânicos foram avaliados através dos testes do micronúcleo e de troca de cromátides irmãs. Uma população controle foi constituída por trabalhadores de escritório. Não foram encontradas associações entre os resultados dos dois testes e o trabalho em laboratório (NAROD et al. 1988).

A aplicação do teste do micronúcleo em trabalhadores expostos a solventes tem revelado alguns importantes resultados.

Trabalhadores expostos a altas concentrações de tolueno, gasolina, acetona, acetato de etila e metileno-difenil-diisocianato no ambiente de trabalho em fábricas de sapatos mostraram um aumento na freqüência de micronúcleos em linfócitos de sangue periférico estatisticamente significativo quando comparado aos controles. Um nível elevado de ácido hipúrico na urina, 
indicador biológico de dose interna da exposição ao tolueno, foi observado para estes trabalhadores (PITARQUE et al. 2002).

Um aumento na freqüência de micronúcleos foi observado em trabalhadores de uma indústria química do Estado de São Paulo expostos a misturas de solventes clorados (percloretileno, tetracloreto de carbono, hexaclorobenzeno), quando comparada com trabalhadores não expostos (SILVA AUGUSTO et al. 1997).

Vinte e um impressores de rotogravura e vinte e um controles foram comparados quanto à frequiência de micronúcleo em linfócitos de sangue periférico. Foi observado um aumento significativo na freqüência de micronúcleos nos trabalhadores expostos e uma correlação entre as dosagens de tolueno no sangue e as frequiências de micronúcleo (NISE et al. 1991).

Uma associação significativa entre a exposição ocupacional a solventes e aumento na frequiência de micronúcleos em mucosa oral foi também observada em frentistas expostos a metanol (GATTÁs et al. 2001) e em pintores expostos a solventes orgânicos presentes nas tintas e tíneres (PINTO et al. 2000).

Leves aumentos, porém não significativos, na freqüência de micronúcleos foram encontrados em trabalhadores expostos a solventes orgânicos em navios petroleiros (NILSSON et al. 1997).

Não foram observadas correlações entre a frequiência de micronúcleos e exposição a estireno em trabalhadores de uma indústria de plásticos na Suécia (HAGMAR et al. 1989), e em frentistas expostos a derivados do petróleo na Espanha (PITARQUE et al. 1996). Nestes últimos trabalhadores, foram encontrados níveis elevados de fenol urinário em relação aos controles.

Recentemente, uma nova técnica além dos testes citogenéticos vem sendo proposta para avaliação de efeitos genotóxicos, inclusive em populações ocupacionalmente expostas a agentes com potencial para estes efeitos (PITARQUE 
et al. 1999a; SOMOROVSKA et al. 1999). Trata-se do Teste do Cometa ou do Ensaio Eletroforético da Célula Única em Gel de Agarose (SCGE - Single Cell Gel Electrophoresis Assay).

A técnica consiste em embeber células (linfócitos ou células de mucosa, por exemplo) em gel de agarose, depositando o material em lâminas e submetendo-o a uma solução de lise de membranas citoplasmática e nuclear. Em seguida, as lâminas são submersas em tampão de eletroforese com o objetivo de desenrolar as fitas de DNA e submetidas a um campo eletroforético. Os fragmentos de DNA resultantes de alterações sofridas pelas células migram em direção à corrente elétrica formando uma cauda. Estes, visualizados na presença de corantes fluorescentes aparecem como figuras semelhantes a "cometas"( SINGH et al. 1988). Um maior número de alterações de DNA podem ser detetadas por este ensaio (ROJAS et al. 1999).

O Teste do Cometa é usado para investigar danos no DNA em termos de quebras de fitas e sítios alcalilábeis e vem sendo aplicado em estudos de biomonitorização de exposições ocupacionais a estireno, cloreto de vinila, 1,3butadieno, pesticidas, corantes, agentes antineoplásicos, solventes orgânicos, entre outros agentes químicos e físicos. A maior parte dos estudos apresentou resultados positivos (MOLLER et al. 2000).

Trabalhadores expostos a solventes orgânicos em uma fábrica de sapatos $(n=34)$ e trabalhadores não-expostos $(n=19)$ foram avaliados através do Teste do Cometa. Os trabalhadores estavam expostos a acetona, gasolina e tolueno, porém, não foram afetados em relação à frequiência de cometas quando comparados aos não-expostos (PITARQUE et al. 1999b). 


\section{OBJETIVOS}

\subsection{Objetivo Geral}

Estimar a exposição ocupacional a solventes orgânicos em trabalhadores de laboratórios químicos de um Instituto de Pesquisa e Prestação de Serviços e avaliar danos genotóxicos nos indivíduos expostos.

\subsection{Objetivos Específicos}

a. Estabelecer uma estratégia de amostragem adequada para a estimativa da exposição ocupacional a solventes orgânicos em trabalhadores de laboratórios;

b. Estimar qualitativa e quantitativamente a exposição ocupacional a solventes orgânicos;

c. Identificar possíveis evidências de genotoxicidade através do uso de testes citogenéticos: Micronúcleo e Cometa (SCGE);

d. Verificar a possível correlação entre a exposição a solventes orgânicos em trabalhadores de laboratórios e danos genotóxicos, medidos através de testes citogenéticos (Micronúcleo e Cometa). 


\section{MATERIAL E MÉTODOS}

\subsection{População Estudada}

\subsubsection{Grupo Exposto}

A fim de se compor o grupo exposto - trabalhadores de laboratórios -, foram contatados dois Institutos de Pesquisa localizados na cidade de São Paulo, através de suas respectivas Diretorias. Havia conhecimento prévio de que estes Institutos eram compostos de diversos laboratórios e que, em alguns destes laboratórios, as atividades ocupacionais incluíam manipulação de solventes orgânicos.

Em reunião com as Diretorias dos Institutos foram apresentados: o projeto de Tese de Doutorado e a avaliação do Comitê de Ética (Anexo I), ambos aprovados por esta Faculdade. Foi realizado formalmente o convite à participação na pesquisa, sendo esclarecidos os seguintes pontos:

- o anonimato dos participantes, assim como do Instituto, seria garantido na redação da Tese e de trabalhos que viessem a ser publicados;

- os resultados das análises realizadas seriam entregues ao Instituto e a cada participante individualmente, assim como a interpretação dos mesmos.

Somente um dos dois Institutos de Pesquisa respondeu positivamente ao nosso convite.

Assim, foi realizada neste Instituto uma visita inicial a todos os laboratórios que o compunham. A partir desta visita e utilizando-se como critério a manipulação de solventes orgânicos em suas atividades ocupacionais, foram selecionados 31 trabalhadores distribuídos em 5 laboratórios. Todos os trabalhadores foram contatados pessoalmente e a todos foram fornecidas informações $e$ esclarecimentos a respeito da pesquisa. Aceitaram participar do estudo 26 dos 31 
trabalhadores contatados, sendo que os 7 que não aceitaram pertenciam a um único laboratório. O aceite foi formalizado através do Termo de Consentimento PósInformado (Anexo II). As características individuais do grupo exposto selecionado são apresentadas na Tabela 3.1.

Durante o período em que se desenvolveu o estudo, foram excluídos 3 indivíduos porque deixaram de trabalhar no Instituto.

Portanto, o grupo exposto passou a ser composto por 23 indivíduos distribuídos em 9 pesquisadores (39\%), 11 estagiários/técnico (48\%) e 3 auxiliares (13\%). 
ㄴ.

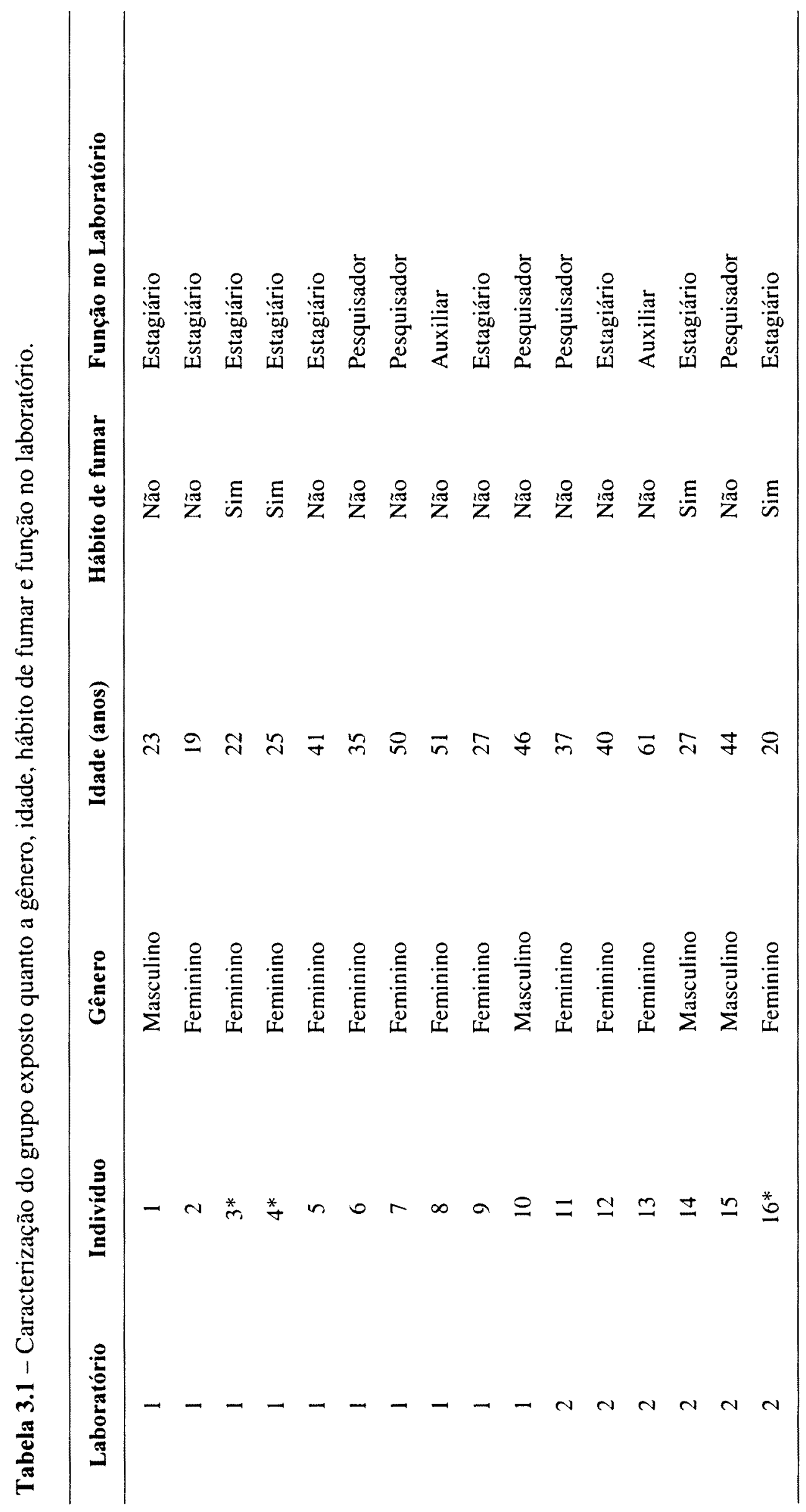


ล

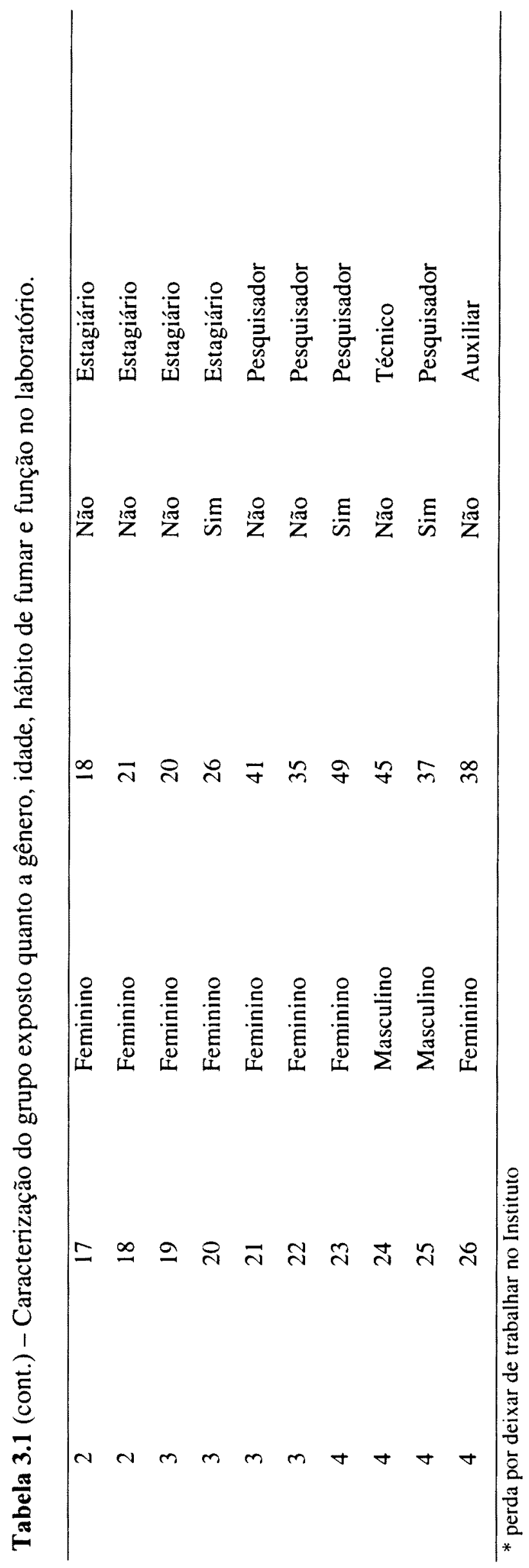




\subsubsection{Grupo Não-exposto}

Para a comparação dos resultados dos testes citogenéticos (avaliação biológica) realizados na população exposta, foi constituído um grupo nãoexposto de 23 indivíduos sem história de exposição a solventes orgânicos, selecionados a partir de funcionários de um escritório localizado na cidade de São Paulo.

Informações e esclarecimentos a respeito da pesquisa foram fornecidos a todos os indivíduos do grupo não-exposto e o aceite de participação foi formalizado através do Termo de Consentimento Pós-Informado (Anexo III).

Os indivíduos do grupo exposto foram pareados com os do grupo não-exposto em relação a gênero, idade (faixa de 10-10 anos) e hábito de fumar.

As características individuais do grupo não-exposto são mostradas na Tabela 3.2. 
Tabela 3.2 - Caracterização do grupo não-exposto quanto a gênero, idade e hábito de fumar.

\begin{tabular}{|c|c|c|c|}
\hline Indivíduo & Gênero & Idade (anos) & Hábito de fumar \\
\hline 27 & Feminino & 19 & Não \\
\hline 28 & Feminino & 63 & Não \\
\hline 29 & Masculino & 49 & Não \\
\hline 30 & Feminino & 22 & Não \\
\hline 31 & Feminino & 39 & Não \\
\hline 32 & Feminino & 20 & Não \\
\hline 33 & Masculino & 34 & Sim \\
\hline 34 & Masculino & 37 & $\operatorname{Sim}$ \\
\hline 35 & Masculino & 20 & Não \\
\hline 36 & Feminino & 25 & Não \\
\hline 37 & Masculino & 44 & Não \\
\hline 38 & Feminino & 35 & Não \\
\hline 39 & Masculino & 21 & Não \\
\hline 40 & Feminino & 42 & Não \\
\hline 41 & Masculino & 41 & Não \\
\hline 42 & Feminino & 55 & Não \\
\hline 43 & Feminino & 56 & Não \\
\hline 44 & Feminino & 46 & Sim \\
\hline 45 & Feminino & 23 & Não \\
\hline 46 & Feminino & 25 & Não \\
\hline 47 & Feminino & 21 & Não \\
\hline 48 & Feminino & 46 & $\operatorname{Sim}$ \\
\hline 49 & Feminino & 40 & Não \\
\hline
\end{tabular}




\title{
3.2 Avaliação Ambiental
}

\subsubsection{Visita Preliminar e Estratégia de Amostragem}

\author{
Uma visita preliminar foi realizada aos 4 laboratórios \\ participantes da pesquisa com a finalidade de estabelecer uma estratégia de \\ amostragem adequada para se estimar a exposição ocupacional a solventes orgânicos \\ no grupo exposto.
}

Um roteiro foi elaborado a fim de tornar a visita preliminar mais produtiva, no qual os seguintes itens seriam observados e devidamente registrados:

- descrição das áreas;

- existência e funcionamento de equipamentos de proteção coletiva (capelas, exaustores, etc.);

- número de trabalhadores e funções ou cargos;

- principais tarefas/atividades realizadas;

- horários e turnos de trabalho;

- principais solventes orgânicos manipulados;

- freqüência de exposição a solventes orgânicos;

- movimentação do pessoal;

- outras substâncias químicas utilizadas nas atividades.

A estratégia de amostragem, aqui compreendida como o conjunto de procedimentos empregados na coleta de amostras representativas da exposição ocupacional, foi estabelecida a partir da análise das informações obtidas na visita preliminar e considerando ainda os seguintes pontos:

- substâncias a serem analisadas;

- equipamentos disponíveis para coleta;

- custo das análises;

- períodos de realização das atividades envolvendo solventes orgânicos;

- condições ambientais dos locais (laboratórios). 


\subsubsection{Coleta e Análise de Amostras}

As coletas das amostras dos solventes orgânicos na atmosfera dos locais de trabalho foram realizadas utilizando-se amostradores passivos ou dosímetros (modelo 3500 - 3M), os quais foram colocados na zona respiratória dos trabalhadores, durante um período representativo da jornada ou ainda durante a realização de determinadas atividades.

Paralelamente a cada coleta foi preenchida uma Ficha de Coleta (Anexo IV) para se obter informações úteis na análise dos resultados.

Foi realizada a análise de um Branco de campo para cada conjunto de amostras, sendo o monitor aberto e fechado no início das coletas e deixado no local de amostragem durante o período das coletas e seguindo todos os passos das amostras.

Todos os monitores passivos foram refrigerados e transportados ao Laboratório Toxikon, onde foram realizadas as análises de solventes orgânicos por cromatografia gasosa capilar, conforme técnicas baseadas nos métodos NIOSH (National Institute for Occupational Safety and Health/USA).

\subsubsection{Questionário}

Foi aplicado a cada trabalhador um questionário (Anexo V) direcionado a obter informações sobre a atividade ocupacional e a exposição a solventes orgânicos e outras substâncias químicas eventualmente presentes, assim como algumas informações pessoais para identificação dos indivíduos. 


\subsection{Avaliação Biológica}

A avaliação biológica citogenética foi realizada através dos Testes do Micronúcleo e do Cometa em linfócitos de sangue periférico.

De cada um dos indivíduos dos grupos exposto ( $n=23$ ) e nãoexposto $(n=23)$ foram coletados cerca de $10 \mathrm{~mL}$ de sangue periférico por punção venosa utilizando sistema a vácuo e tubos heparinizados (Liquemine ${ }^{\circledR}$, Roche). Após sedimentação espontânea das hemácias, foi realizada a retirada do anel de leucócitos e pequena quantidade de plasma e soro. Este material foi utilizado para cultura em ambos os Testes: Micronúcleo e Cometa.

\subsubsection{Teste do Micronúcleo (MN)}

Culturas de linfócitos em duplicata (A e B) foram realizadas para cada uma das 43 amostras de sangue coletadas, utilizando meio RPMI 1640 (Gibco) contendo Fito-hemaglutinina M (Difco), esta última com o objetivo de estimular a divisão das células. As culturas foram mantidas em estufa a $37^{\circ} \mathrm{C}$ por um período de 72 horas.

Após 44 horas do início da incubação, os linfócitos foram tratados com Citocalasina B (Sigma) a fim de bloquear a citocinese e acumular células que se dividiram somente uma vez, obtendo-se assim, células binucleadas.

Ao final das 72 horas de incubação, os conteúdos dos meios de cultura foram centrifugados e os sobrenadantes desprezados. Os sedimentos contendo os linfócitos foram lavados e fixados com solução de metanol-ácido acético glacial (3:1). Parte deste material foi utilizada para preparação das lâminas e outra parte armazenada em congelador. As lâminas foram coradas pelo Método de Feulgen: reativo de Schiff por 90 minutos e Fast Green a $1 \%$ por 10 minutos. 
A sequência do procedimento utilizado para o teste do Micronúcleo é sintetizada na Figura 3.1.

Para a determinação da frequiência de micronúcleos, foram analisados 1.000 linfócitos binucleados por indivíduo (500 linfócitos por cultura). Micronúcleo foi definido como um corpúsculo citoplasmático de forma arredondada, contorno regular e bem delimitado, com coloração e textura de cromatina em plano focal semelhante aos núcleos principais e tamanho de no máximo $1 / 3$ dos núcleos principais (FENECH 1993).

A análise dos micronúcleos foi realizada em microscópio NIKON modelo alphaphot-2 YS2, com objetiva de 40x. Aumento de 100x foi utilizado para confirmação dos micronúcleos encontrados. 


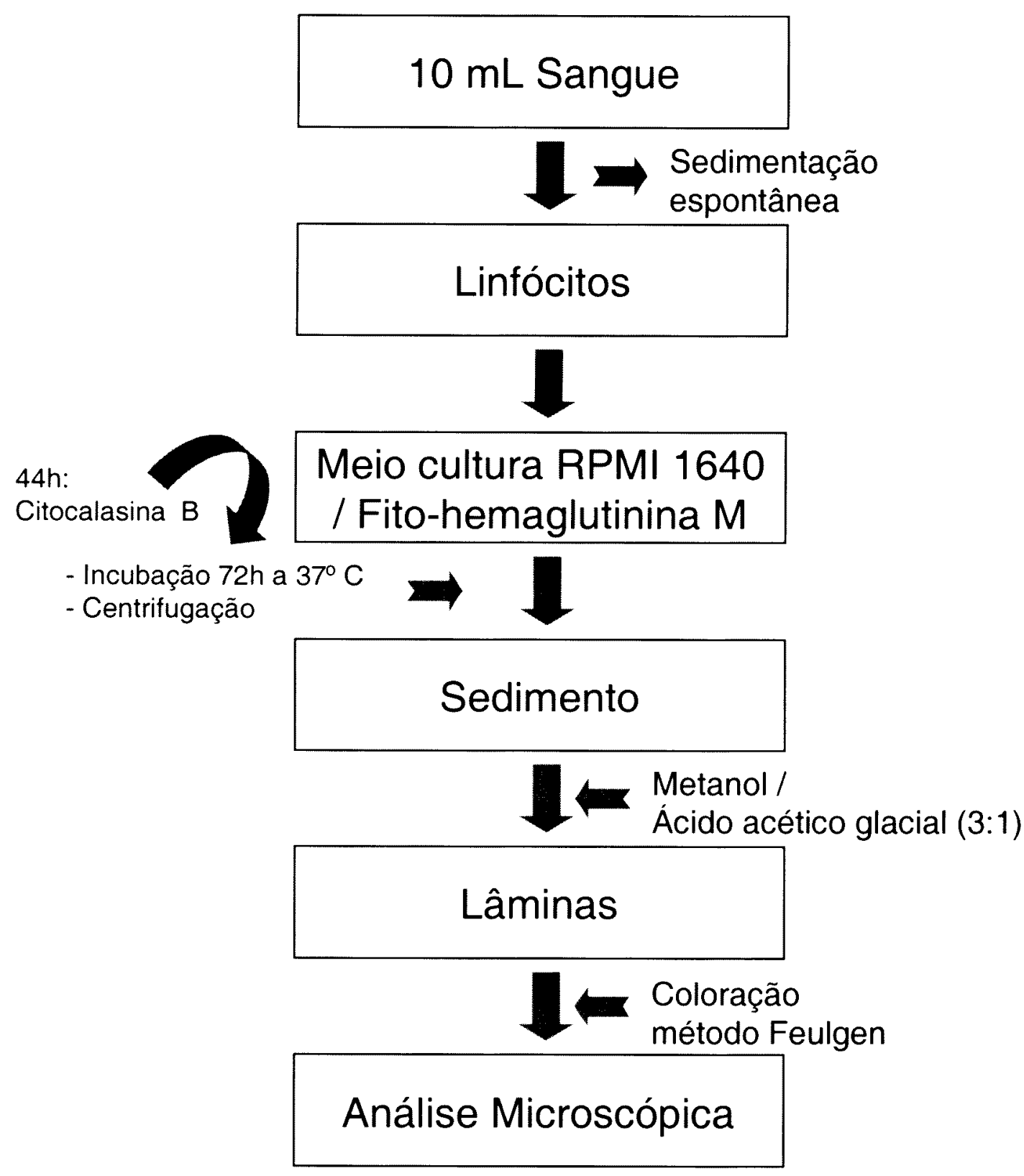

Figura 3.1 - Fluxograma do procedimento utilizado para o Teste do Micronúcleo em linfócitos de sangue periférico. 


\subsubsection{Teste do Cometa}

Para o Teste do Cometa, o material constituído pelo anel de leucócitos e pequena quantidade de plasma e soro foi adicionado ao meio de cultura RPMI 1640 (Gibco) numa proporção de 10\%.

Uma cultura controle positivo da reação foi preparada adicionando-se peróxido de hidrogênio $\left(\mathrm{H}_{2} \mathrm{O}_{2}\right) 30$ volumes ao meio numa proporção de $10 \%$.

Todas as culturas foram mantidas em estufa a $37^{\circ} \mathrm{C}$ por 1 hora. Após este período, o material total de cada cultura foi centrifugado, o sobrenadante desprezado e o sedimento dividido em 3 alíquotas de $6 \mu \mathrm{L}$ colocadas em microtubos. A cada microtubo foi adicionado $100 \mu \mathrm{L}$ de solução de agarose com baixo ponto de fusão (Merck) a $0,07 \%$ dissolvida em tampão fosfato $\mathrm{pH} 7,4$ a $37^{\circ} \mathrm{C}$.

O material total de cada microtubo foi utilizado para preparo de uma lâmina (segunda camada). Assim, para cada cultura (ou amostra) foram preparadas 3 lâminas.

As lâminas foram previamente imersas em solução de agarose de ponto de fusão normal (Merck) a $1 \%$ dissolvida em PBS pH 7,4 a $45^{\circ} \mathrm{C}$, conservadas em geladeira $\left(4^{\circ} \mathrm{C}\right)$ por pelo menos 10 minutos para polimerização do gel de agarose (primeira camada) e depois mantidas a temperatura ambiente por 30 minutos.

A seguir, as lâminas foram:

a) colocadas em geladeira $\left(4^{\circ} \mathrm{C}\right)$ por 7 minutos para polimerização do gel;

b) colocadas em cuba de vidro contendo solução de lise de membranas $(\mathrm{NaCl} 2,5 \mathrm{M}$, $\mathrm{Na}_{2}$ EDTA $100 \mathrm{mM}$, TRIS 10mM, DMSO (dimetil-sulfóxido) 10\%, Sarcosinato de sódio $1 \%$, Triton-X $1 \%) \mathrm{pH} 10$ por 1,5 horas;

c) lavadas em PBS (Phosphate Buffer Saline) pH 7,4 por 15 minutos; 
d) colocadas em cuba de eletroforese contendo tampão de eletroforese ( $\mathrm{Na}_{2}$ EDTA $1 \mathrm{mM}, \mathrm{NaOH} 300 \mathrm{mM}$ ) pH 13,2 por 60 minutos para o desenrolamento do DNA;

e) submetidas a uma corrente de $25 \mathrm{~V}$ e $300 \mathrm{~mA}$ por 30 minutos;

f) neutralizadas em solução TRIS $0,4 \mathrm{M}-\mathrm{pH} 7,5$ em 3 etapas de 5 minutos;

g) fixadas em etanol absoluto por 10 minutos.

Todas as etapas desta sequiência foram realizadas na ausência de iluminação e as etapas a até e foram realizadas a $4^{\circ} \mathrm{C}$.

$\mathrm{O}$ material fixado em lâminas foi armazenado em geladeira e corado no momento da leitura com solução de brometo de etídio (Merck) a 20 $\mu \mathrm{g} / \mathrm{mL}$.

A seqüência do procedimento utilizado para o Teste do Cometa é resumida na Figura 3.2.

A análise qualitativa do Teste do Cometa foi realizada observando-se 100 células por cultura (ou indivíduo). Os cometas foram classificados de 0 a 4 , de acordo com a morfologia das células, ou seja, avaliando-se o tamanho da cabeça, que corresponde ao DNA íntegro da célula (nucleóide), e o tamanho da cauda, que corresponde ao DNA danificado (COLLINS et al. 1995, modificado):

- Classe zero (0): apresenta apenas nucleóide sem cauda;

- Classe um (1): apresenta cauda pequena;

- Classe dois (2): apresenta nucleóide e cauda de tamanhos médios;

- Classe três (3): apresenta nucleóide médio e cauda longa;

- Classe quatro (4): formação de cometa com cauda muito grande em comparação ao nucleóide ou cabeça muito pequena.

Para cada indivíduo foi gerado um escore obtido da multiplicação do número total de cometas em cada classe pelo número da classe, ou seja, o total de cometas da classe 0 multiplicado por 0 , o total de cometas da classe 1 
multiplicado por 1 , e assim sucessivamente até a classe 4 . Para cada indivíduo a somatória dos valores obtidos para as 5 classes poderia variar de 0 a 400 (COLLINS et al. 1995).

A análise dos cometas foi realizada em fotomicroscópio de epifluorescência ZEISS modelo Axioskop utilizando objetiva de 40x.

\subsubsection{Questionário}

Para cada indivíduo amostrado (expostos e não-expostos) na avaliação biológica foi administrado um questionário a fim de se obter informações relacionadas a fatores que influenciam na frequêencia de micronúcleos e de cometas (Anexo VI). 


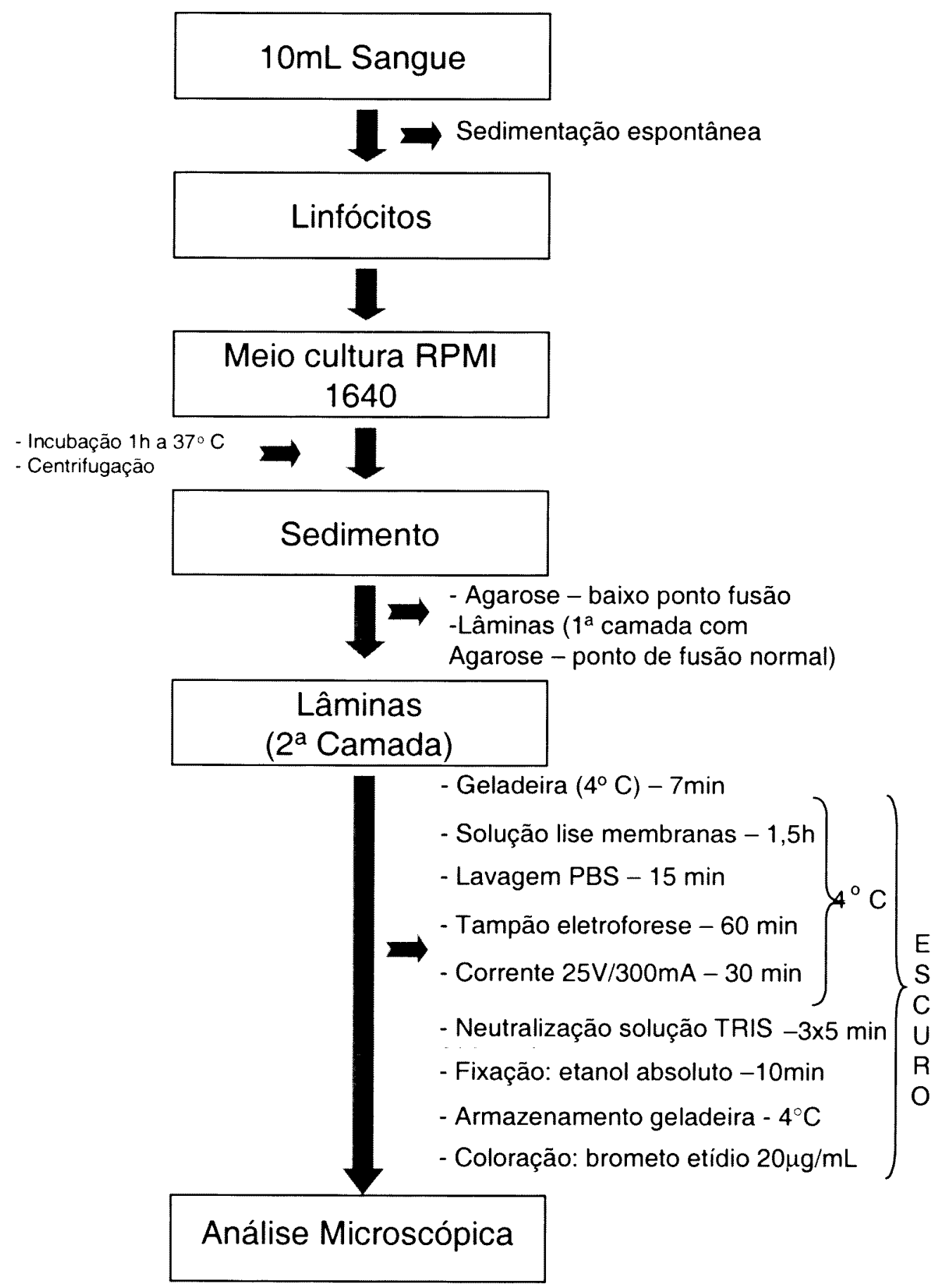

Figura 3.2 - Fluxograma do procedimento utilizado para o Teste do Cometa em linfócitos de sangue periférico. 


\subsection{Tratamento dos Dados}

Os dados obtidos nas avaliações ambientais e biológicas, assim como nos questionários aplicados foram compilados em um banco de dados gerado em microcomputador utilizando-se o programa Microsoft ${ }^{\circledR}$ Excel 97 e a partir do qual foram realizadas as análises estatísticas.

\subsubsection{Avaliação Ambiental}

As concentrações ambientais dos solventes orgânicos foram comparadas com os respectivos Limites de Exposição Ocupacionais de Concentração Média Ponderada pelo Tempo - TLV-TWA (Threshold Limit Values-Time Weighted Average) propostos pela ACGIH (American Conference of Governmental Industrial Hygienists-2002).

Foram calculados os Índices de Exposição (IE) dividindo-se as concentrações ambientais encontradas pelo Limite de Exposição Ocupacional correspondente para cada solvente. Foi realizado o somatório dos índices de exposição para os solventes orgânicos com o mesmo efeito crítico (base do TLV) em cada amostra.

\subsubsection{Avaliação Biológica}

A freqüência de Micronúcleos e de Cometas entre os grupos exposto e não-exposto foi comparada utilizando-se o teste do Qui-quadrado com correção de Yates (significância estabelecida como $\mathrm{P}<0,05$ ). 


\subsubsection{Correlação entre a Avaliação Ambiental e a Biológica}

A possível correlação entre exposição a solventes orgânicos nos trabalhadores de laboratórios e danos genotóxicos, estes últimos avaliados através da freqüência de Micronúcleos, foi verificada através do cálculo do Coeficiente de Correlação de Pearson.

\section{RESULTADOS}

\subsection{Avaliação Ambiental}

\subsubsection{Visita Preliminar}

Os resultados das observações realizadas na Visita Preliminar são descritos a seguir:

\section{LABORATÓRIO I:}

a) Descrição da área: ocupava parte de 2 andares de um prédio de 3 andares e era composto de 8 salas de Laboratórios, 4 salas de escritório, 1 sala de descarte e lavagem, 1 sala de depósito de material técnico e 1 corredor contendo geladeiras e congeladores para armazenamento de amostras. As salas de Laboratórios tinham cerca de $20 \mathrm{~m}^{2}$ cada uma, sendo que 2 delas (salas de extração/evaporação) apresentavam equipamentos de proteção coletiva - capela e exaustor - em funcionamento;

b) Número de trabalhadores: 4 pesquisadores, 6 estagiários e 1 auxiliar (total =11). Dos 11 trabalhadores, 1 pesquisador não aceitou participar da pesquisa por não poder doar sangue por recomendação médica;

c) Principais tarefas realizadas: eram realizadas análises de rotina e principalmente de pesquisa utilizando técnicas de química analítica (extração com solventes orgânicos, cromatografia) e técnicas microbiológicas. As atividades técnicas no Laboratório eram realizadas principalmente pelos estagiários, enquanto que os 
pesquisadores que outrora exerciam estas atividades, atualmente dividiam seu tempo entre algumas atividades técnicas no laboratório, pesquisa teórica e coordenação das pesquisas. O funcionário auxiliar realizava atividades de descarte e lavagem dos materiais utilizados nos procedimentos técnicos;

d) Horários e turnos de trabalho: turno integral para os pesquisadores ( 8 horas/dia), meio período para os estagiários (cerca de 4 horas/dia) e diferenciado para o auxiliar ( 3 dias de 8 horas/semana);

e) Freqüência da exposição a solventes orgânicos: como grande parte das atividades realizadas eram de pesquisa, havia muita variação nas técnicas utilizadas e, portanto, as atividades que envolviam solventes orgânicos não eram regulares. No momento desta visita preliminar, haviam pesquisas em que as atividades com solventes orgânicos estavam sendo diárias e outras em que as atividades com solventes orgânicos eram realizadas 1 a 2 vezes por semana. Conseqüentemente, os pesquisadores e estagiários responsáveis pelas primeiras pesquisas estavam mais freqüentemente expostos e os responsáveis pelas demais pesquisas estavam expostos com menor frequêencia. Vale lembrar que as pesquisas tinham duração limitada e o quadro acima poderia ser alterado e até mesmo invertido, o que é comum em laboratórios deste tipo;

f) Movimentação do pessoal: todos os trabalhadores circulavam por toda a área do Laboratório, podendo apresentar exposição mesmo sem estar exercendo as atividades técnicas de manipulação de solventes orgânicos;

g) Principais solventes orgânicos manipulados: metanol, tolueno, n-hexano, acetato de etila, diclorometano, acetona;

h) Outras substâncias químicas manipuladas: padrões de pesticidas, pesticidas radioativos $\left(\mathrm{C}^{14}\right)$; ácidos (sulfúrico, clorídrico, fosfórico e acético).

\section{LABORATÓRIO 2:}

a) Descrição da área: ocupava parte de um andar de um prédio de 5 andares, composto de 3 salas de Laboratórios (sala de extração, sala de clean-up, sala de cromatografia), e 1 sala de escritório. A lavagem dos materiais era realizada num anexo entre as salas de extração e clean-up. As salas de Laboratórios apresentavam cerca de $40 \mathrm{~m}^{2}$ cada uma e todas tinham capelas em funcionamento; 
b) Número de trabalhadores: 2 pesquisadores, 5 estagiários, 2 auxiliares (total $=9$ ), sendo um auxiliar administrativo que não exerce atividades técnicas e, portanto não fez parte do grupo exposto;

c) Principais tarefas realizadas: eram realizadas análises de rotina e de pesquisa utilizando técnicas de química analítica (extração com solventes orgânicos, cromatografia). As atividades de extração eram realizadas principalmente pelos estagiários e em parte pelos pesquisadores. As atividades de cromatografia eram realizadas pelos pesquisadores, que também exerciam atividades de pesquisa teórica e administrativas. O funcionário auxiliar realizava as atividades de lavagem dos materiais utilizados nos procedimentos técnicos;

d) Horários e turnos de trabalho: turno integral para os pesquisadores e 2 estagiários e auxiliar ( 8 horas/dia), meio período para 3 estagiários (cerca de 4 horas/dia);

e) Frequiência da exposição a solventes orgânicos: as atividades realizadas neste Laboratório tinham maior regularidade, ou seja, os procedimentos envolvendo solventes orgânicos (extração e cromatografia) faziam parte da rotina diária dos trabalhadores levando a uma frequiência mais constante de exposição, embora também dependesse da demanda de serviços solicitados;

f) Movimentação do pessoal: todos os trabalhadores circulavam por toda a área do Laboratório, podendo apresentar exposição mesmo sem estar exercendo as atividades técnicas de manipulação de solventes orgânicos;

g) Principais solventes orgânicos manipulados: diclorometano, acetona, ciclohexano, iso-octano, acetato de etila, n-hexano, tolueno;

h) Outras substâncias químicas manipuladas: padrões de pesticidas, sílica (para empacotamento de colunas).

\section{LABORATÓRIO 3:}

a) Descrição da área: ocupava parte de 2 andares de um prédio de 3 andares e era composto de 8 salas de Laboratórios (salas de extração, cromatografia, cultura, balança); 2 salas de geladeiras, 2 salas de lavagem, 1 almoxarifado e algumas salas de estudo/reuniões. As salas de Laboratório tinham em média $20 \mathrm{~m}^{2}$ cada uma e apresentavam capelas e exaustores funcionando em sua maioria (salas de extração e cromatografia); 
b) Número de trabalhadores: 5 pesquisadores, 6 estagiários (total $=11$ ). Dos 11 trabalhadores, somente 4 ( 2 estagiários e 2 pesquisadores) exerciam atividades envolvendo solventes orgânicos $\mathrm{e}$, portanto, foram selecionados para o grupo exposto;

c) Principais tarefas realizadas: eram realizadas análises de rotina e de pesquisa utilizando técnicas de química analítica (extração com solventes orgânicos, cromatografia) e ensaios biológicos. As atividades de extração e cromatografia eram realizadas principalmente pelos estagiários e em parte pelos pesquisadores. Os pesquisadores dividiam seu tempo de trabalho entre atividades técnicas no laboratório, pesquisa teórica e atividades administrativas;

d) Horários e turnos de trabalho: turno integral para os pesquisadores e 1 estagiário e meio período para 1 estagiário (cerca de 4 horas/dia);

e) Frequiência da exposição a solventes orgânicos: assim como no Laboratório 1, as atividades não eram regulares. Procedimentos envolvendo solventes orgânicos eram desenvolvidos em torno de 2 vezes (dias) por semana;

f) Movimentação do pessoal: todos os trabalhadores circulavam por toda a área do Laboratório, podendo apresentar exposição mesmo sem estar exercendo as atividades técnicas de manipulação de solventes orgânicos;

g) Principais solventes orgânicos manipulados: éter, metanol, clorofórmio, etanol, nhexano, acetato de etila, acetonitrila;

h) Outras substâncias químicas manipuladas: padrões de micotoxinas.

\section{LABORATÓRIO 4:}

a) Descrição da área: ocupava parte de 1 andar de um prédio de 5 andares e era composto de 3 salas de Laboratórios (sala de testes físico-químicos, sala de extração, sala de cromatografia) e 1 sala de escritório. A lavagem dos materiais era realizada num anexo entre as salas de testes físico-químicos e extração. As salas de Laboratórios apresentavam cerca de $40 \mathrm{~m}^{2}$ cada uma e a sala de extração possuía capela em funcionamento;

b) Número de trabalhadores: 2 pesquisadores, 1 técnico e 1 auxiliar (total=4);

c) Principais tarefas realizadas: eram realizadas análises de rotina (prestação de serviços) e de pesquisa utilizando testes físico-químicos e técnicas de química 
analítica (extração com solventes orgânicos, cromatografia). As atividades acima eram realizadas principalmente pelos pesquisadores e também pelo técnico. A lavagem do material utilizado nas análises era realizada pelo auxiliar;

d) Horários e turnos de trabalho: turno integral para os pesquisadores e auxiliar e meio período para o técnico (cerca de 4 horas/dia);

e) Frequiência da exposição a solventes orgânicos: a regularidade das atividades desenvolvidas neste Laboratório e, portanto, a freqüência da exposição a solventes orgânicos era dependente principalmente da demanda de serviços solicitados. Assim, o trabalho envolvendo solventes orgânicos podia variar de alguns dias a todos os dias na semana:

f) Movimentação do pessoal: todos os trabalhadores circulavam por toda a área do Laboratório, podendo apresentar exposição mesmo sem estar exercendo as atividades técnicas de manipulação de solventes orgânicos;

g) Principais solventes orgânicos manipulados: metanol, acetona, acetonitrila, diclorometano, isso-propanol, n-hexano, acetato de etila, ciclo-hexano, tetrahidrofurano (THF), clorofórmio, etanol;

h) Outras substâncias químicas manipuladas: padrões de pesticidas, ácidos (fosfórico, perclórico, acético, fórmico).

\subsubsection{Estratégia de Amostragem}

A seguinte estratégia de amostragem para estimar a exposição ocupacional dos trabalhadores de laboratórios que compunham o grupo exposto foi estabelecida:

a) coletas pessoais realizadas por meio de amostradores passivos;

b) amostras únicas por todo o período de trabalho;

c) analisar todos os solventes orgânicos presentes nas amostras e em quantidades significativas;

d) divisão em grupos homogêneos por função (pesquisador, estagiário, auxiliar);

e) números de indivíduos amostrados e amostras por grupo são mostrados na Tabela 4.1 . 
Tabela 4.1 - Indivíduos amostrados e números de amostras por grupo e por laboratório.

\begin{tabular}{clccc}
\hline Laboratório & \multicolumn{1}{c}{ Função } & $\begin{array}{c}\text { Número } \\
\text { Trabalhadores }\end{array}$ & $\begin{array}{c}\text { Indivíduos } \\
\text { Amostrados }\end{array}$ & Número Amostras \\
\hline \multirow{2}{*}{1} & Pesquisador & 3 & 0 & 0 \\
& Estagiário & 6 & 2 & 3 \\
& Auxiliar & 1 & 0 & 0 \\
\hline \multirow{2}{*}{2} & Pesquisador & 2 & 1 & 2 \\
& Estagiário & 5 & 1 & 2 \\
& Auxiliar & 1 & 1 & 2 \\
\hline \multirow{2}{*}{3} & Pesquisador & 2 & 0 & 0 \\
& Estagiário & 2 & 2 & 3 \\
\hline \multirow{2}{*}{4} & Pesquisador & 2 & 1 & 2 \\
& Técnico & 1 & 0 & 0 \\
\hline \multirow{2}{*}{ TOTAL } & Auxiliar & 1 & 0 & 14 \\
\hline
\end{tabular}

* Foram perdidos 3 indivíduos no decorrer do estudo, restando 23 indivíduos. 


\subsubsection{Estimativa Qualitativa e Quantitativa da Exposição}

Os resultados das análises das amostras ambientais de solventes orgânicos conduzidas conforme Tabela 4.1 são apresentados na Tabela 4.2.

A Tabela 4.3 mostra os Índices de Exposição calculados de acordo com os efeitos críticos (base do TLV) em todas as amostras analisadas.

As Tabelas 4.4 a 4.6 apresentam as concentrações ambientais e a média geométrica calculada para os solventes benzeno, clorofórmio e diclorometano, os quais são considerados carcinogênicos. 


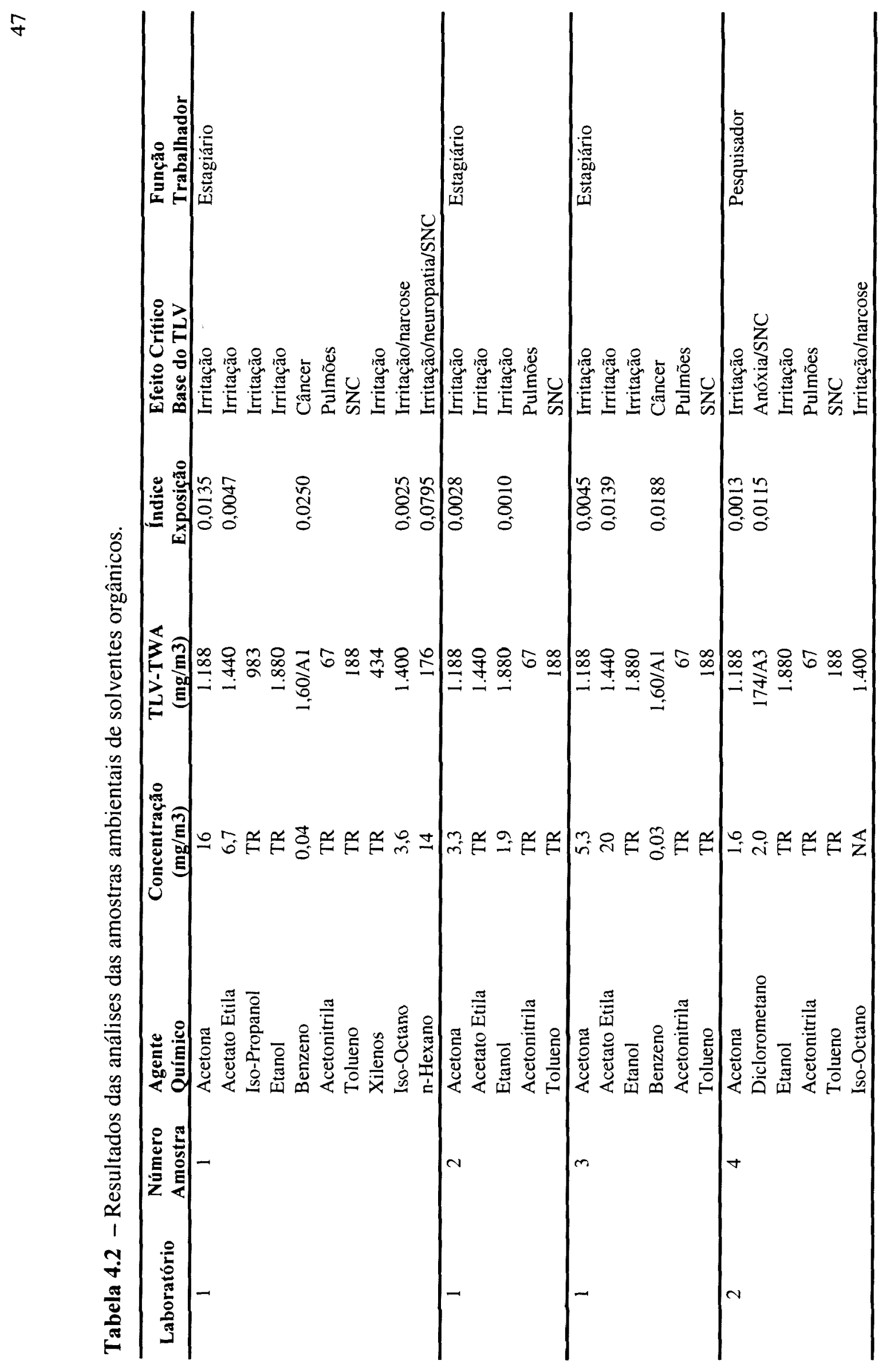




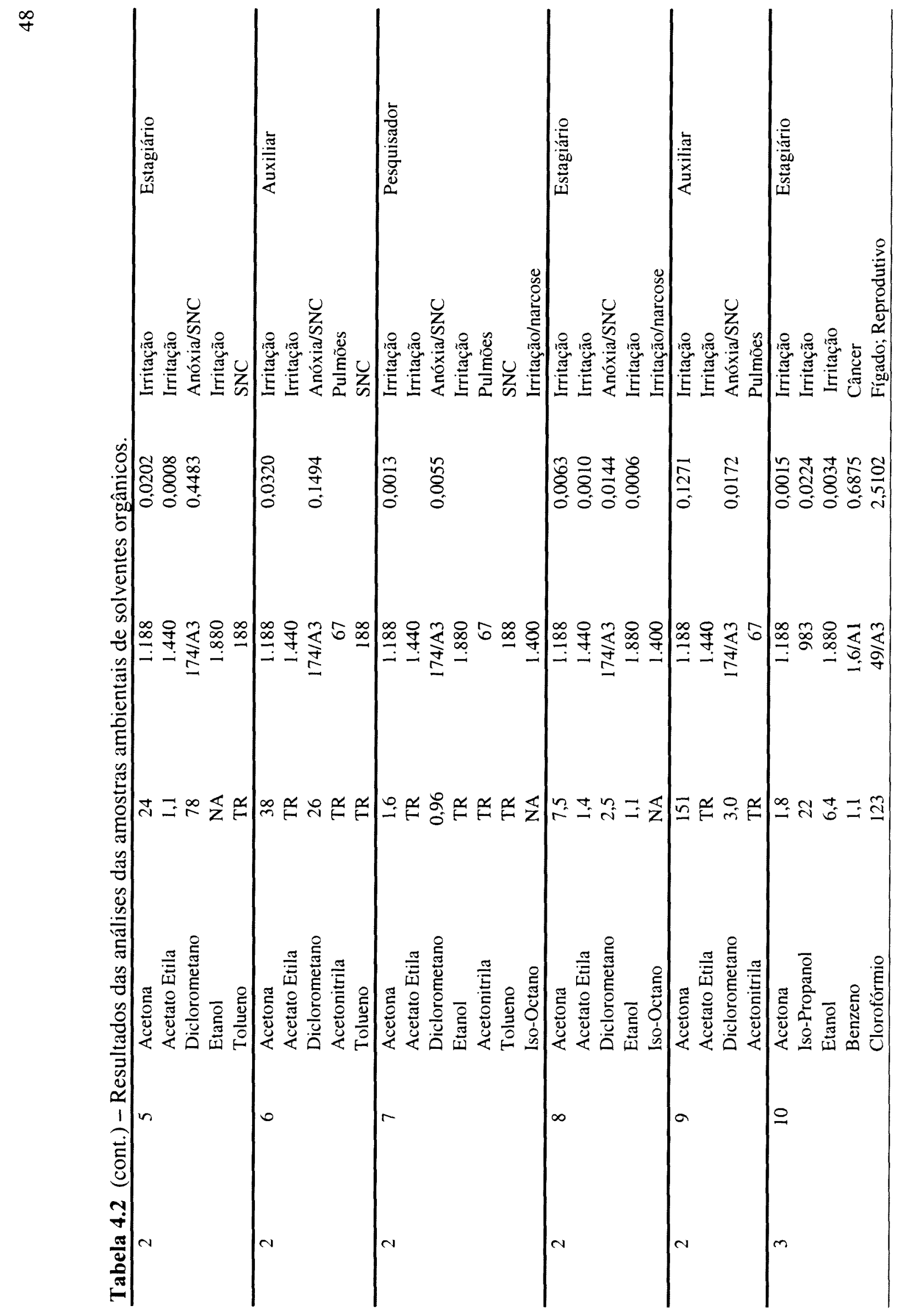


$q$

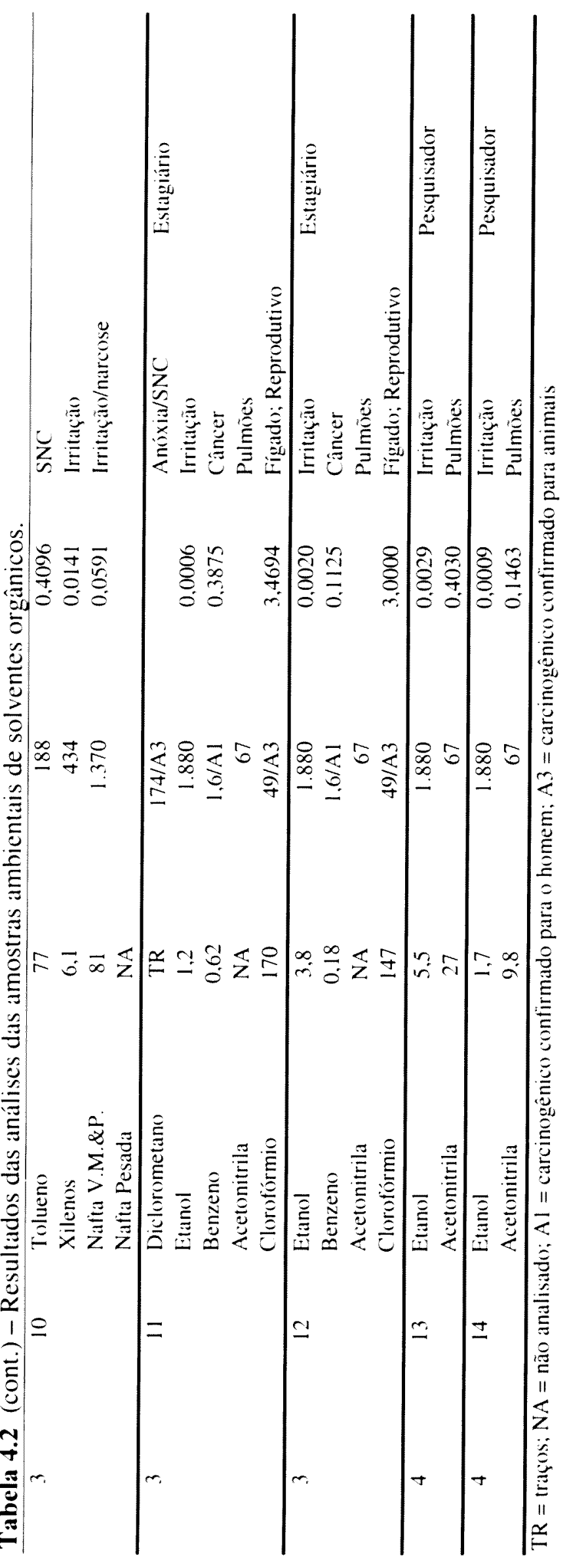


Tabela 4.3 - Somatório dos Índices de Exposição nas amostras analisadas de acordo com os efeitos críticos (base do TLV).

\begin{tabular}{|c|c|c|c|}
\hline Amostra & $\begin{array}{l}\text { Função } \\
\text { Laboratório }\end{array}$ & Índice Exposição & $\begin{array}{l}\text { Efeito Crítico } \\
\text { Base do TLV }\end{array}$ \\
\hline \multirow[t]{4}{*}{1} & Estagiário & 0,0182 & Irritação \\
\hline & & 0.0025 & Irritação/narcose \\
\hline & & 0.0795 & Irritação/neuropatia/SNC \\
\hline & & 0,0250 & Câncer \\
\hline 2 & Estagiário & 0,0038 & Irritação \\
\hline \multirow[t]{2}{*}{3} & Estagiário & 0,0184 & Irritação \\
\hline & & 0.0188 & Câncer \\
\hline \multirow[t]{2}{*}{4} & Pesquisador & 0.0013 & Irritação \\
\hline & & 0.0115 & Anóxia/SNC \\
\hline \multirow[t]{2}{*}{5} & Estagiário & 0.0210 & Irritação \\
\hline & & 0,4483 & Anóxia/SNC \\
\hline \multirow[t]{2}{*}{6} & Auxiliar & 0,1494 & Anóxia/SNC \\
\hline & & 0.0320 & Irritação \\
\hline \multirow[t]{2}{*}{7} & Pesquisador & 0.0013 & Irritação \\
\hline & & 0.0055 & Anóxia/SNC \\
\hline \multirow[t]{2}{*}{8} & Estagiário & 0,0079 & Irritação \\
\hline & & 0,0144 & Anóxia/SNC \\
\hline \multirow[t]{2}{*}{9} & Auxiliar & 0.1271 & Irritação \\
\hline & & 0,0172 & Anóxia/SNC \\
\hline \multirow[t]{5}{*}{10} & Estagiário & 0.0414 & Irritação \\
\hline & & 0,0591 & Irritação/narcose \\
\hline & & 2,5100 & Fígado; Reprodutivo \\
\hline & & 0,6875 & Câncer \\
\hline & & 0.4096 & $\mathrm{SNC}$ \\
\hline \multirow[t]{3}{*}{11} & Estagiário & 0.0006 & Irritação \\
\hline & & 0,3875 & Câncer \\
\hline & & 3,4700 & Fígado; Reprodutivo \\
\hline \multirow[t]{3}{*}{12} & Estagiário & 0.0020 & Irritação \\
\hline & & 0,1125 & Câncer \\
\hline & & 3,0000 & Fígado; Reprodutivo \\
\hline \multirow[t]{2}{*}{13} & Pesquisador & 0.0029 & Irritação \\
\hline & & 0,4030 & Pulmões \\
\hline \multirow[t]{2}{*}{14} & Pesquisador & 0,0009 & Irritação \\
\hline & & 0.1463 & Anóxia/Pulmões \\
\hline
\end{tabular}


Tabela 4.4 - Concentrações ambientais para benzeno - classe Al (carcinogênico confirmado para o homem).

\begin{tabular}{|c|c|c|}
\hline Laboratório & Número Amostra & $\begin{array}{c}\text { Concentração } \\
(\mathbf{m g} / \mathbf{m} 3)\end{array}$ \\
\hline 1 & 1 & 0,04 \\
\hline 1 & 3 & 0,03 \\
\hline 3 & 10 & 1,10 \\
\hline 3 & 11 & 0,62 \\
\hline \multirow[t]{4}{*}{3} & 12 & 0,18 \\
\hline & GM & 0,17 \\
\hline & GSD & 4,96 \\
\hline & TLV-TWA (mg/m3) & 1.60 \\
\hline
\end{tabular}

GM = Média Geométrica; GSD = Desvio Padrão Geométrico;

TLV-TWA = Limite de Exposição Ocupacional de Concentração Média Ponderada pelo Tempo (Threshold Limit Values - Time Weighted Average).

Tabela 4.5 - Concentrações ambientais para clorofórmio - classe A3 (carcinogênico confirmado para animais).

\begin{tabular}{ccc}
\hline Laboratório & Número Amostra & $\begin{array}{c}\text { Concentração } \\
(\mathbf{m g} / \mathbf{m 3})\end{array}$ \\
\hline 3 & 10 & 123 \\
3 & 11 & 170 \\
3 & 12 & 147 \\
\hline & GM & 145 \\
& GSD & 1,2 \\
\hline
\end{tabular}

GM = Média Geométrica; GSD = Desvio Padrão Geométrico;

TLV-TWA = Limite de Exposição Ocupacional de Concentração Média Ponderada pelo Tempo (Threshold Limit Values - Time Weighted Average). 
Tabela 4.6 - Concentrações ambientais para diclorometano - classe A3 (carcinogênico confirmado para animais).

\begin{tabular}{|c|c|c|}
\hline Laboratório & Número Amostra & $\begin{array}{c}\text { Concentração } \\
(\mathrm{mg} / \mathrm{m} 3)\end{array}$ \\
\hline 2 & 4 & 2,0 \\
\hline 2 & 5 & 78.0 \\
\hline 2 & 6 & 26.0 \\
\hline 2 & 7 & 0.96 \\
\hline 2 & 8 & 2,5 \\
\hline \multirow[t]{4}{*}{2} & 9 & 3.0 \\
\hline & GM & 5.55 \\
\hline & GSD & 5.49 \\
\hline & TLV-TWA (mg/m3) & 174 \\
\hline
\end{tabular}

GM = Média Geométrica; GSD = Desvio Padrão Geométrico;

TLV-TWA = Limite de Exposição Ocupacional de Concentração Média Ponderada pelo Tempo (Threshold Limit Values - Time Weighted Average).

\subsection{Avaliação Biológica}

Das quarenta e seis amostras de sangue coletadas para a realização dos ensaios citogenéticos, duas amostras (indivíduos 11 e 22) do grupo exposto e uma amostra do grupo não-exposto (indivíduo 40) foram perdidas por motivos de escassez de material após o processamento descrito em 3.3.1 para o Teste do MN, o que impossibilitou a análise microscópica. Para o Teste do Cometa, descrito em 3.3.2, problemas na técnica impossibilitaram a leitura da maior parte das amostras. Portanto, foram analisadas 21 amostras do grupo exposto e 22 amostras do grupo não-exposto, para o Teste do $\mathrm{MN}$; enquanto que para o Teste do Cometa somente foi possível a análise de 6 amostras do grupo exposto e 4 amostras do grupo não-exposto. 


\subsubsection{Teste do Micronúcleo (MN)}

A Tabela 4.7 apresenta os resultados individuais das freqüências de $\mathrm{MN}$ em 1.000 células binucleadas para os grupos exposto e nãoexposto.

A comparação dos resultados de frequiência total de $\mathrm{MN}$ nos grupos exposto e não-exposto, e por faixa etária, gênero e hábito de fumar, é mostrada nas tabelas 4.8 a 4.11 .

Nas Tabelas 4.12 e 4.13 são apresentadas as frequiências de $\mathrm{MN}$ por função e por laboratório, respectivamente.

\subsubsection{Teste do Cometa}

Os resultados do Teste do Cometa para 6 indivíduos do grupo exposto e 4 indivíduos do grupo não-exposto são mostrados na Tabela 4.13.

\subsection{Correlação entre a Avaliação Ambiental e a Biológica}

As correlações entre as avaliações ambiental e biológica, utilizando respectivamente, tempo de exposição a solventes em laboratório e frequência de $\mathrm{MN}$ em 1.000 células binucleadas, são mostradas na Tabela $4.14 \mathrm{e}$ Figura 4.1. O Coeficente de Correlação de Pearson calculado para a sequiência de dados acima foi de 0,38 (fraca correlação positiva).

\subsection{Questionário}

Um resumo das informações obtidas através dos questionários (Anexo V e VI) é mostrado nas Tabelas 4.15 e 4.16. 
Tabela 4.7 - Frequiência de MN em 1.000 células binucleadas de cada indivíduo da população estudada.

\begin{tabular}{|c|c|}
\hline Indivíduo & Freqüiência MN/1.000 células \\
\hline \multicolumn{2}{|c|}{ Grupo Exposto } \\
\hline 1 & 0 \\
\hline 2 & 1 \\
\hline 5 & 3 \\
\hline 6 & 4 \\
\hline 7 & 10 \\
\hline 8 & 4 \\
\hline 9 & 8 \\
\hline 10 & 4 \\
\hline 12 & 2 \\
\hline 13 & 7 \\
\hline 14 & 3 \\
\hline 15 & 3 \\
\hline 17 & 1 \\
\hline 18 & 2 \\
\hline 19 & 6 \\
\hline 20 & 12 \\
\hline 21 & 3 \\
\hline 23 & 7 \\
\hline 24 & 7 \\
\hline 25 & 10 \\
\hline 26 & 2 \\
\hline \multicolumn{2}{|c|}{ Grupo Näo-exposto } \\
\hline 27 & 1 \\
\hline 28 & 1 \\
\hline 29 & 0 \\
\hline 30 & 1 \\
\hline 31 & 4 \\
\hline 32 & 2 \\
\hline 33 & 1 \\
\hline 34 & 1 \\
\hline 35 & 0 \\
\hline 36 & 1 \\
\hline 37 & 2 \\
\hline 38 & 1 \\
\hline 39 & 2 \\
\hline
\end{tabular}


Tabela 4.7 (cont.) - Frequiência de MN em 1.000 células binucleadas de cada indivíduo da população estudada.

\begin{tabular}{ll}
\hline 41 & 1 \\
42 & 1 \\
43 & 3 \\
44 & 2 \\
45 & 1 \\
46 & 2 \\
47 & 3 \\
48 & 7 \\
49 & 5 \\
\hline
\end{tabular}


in

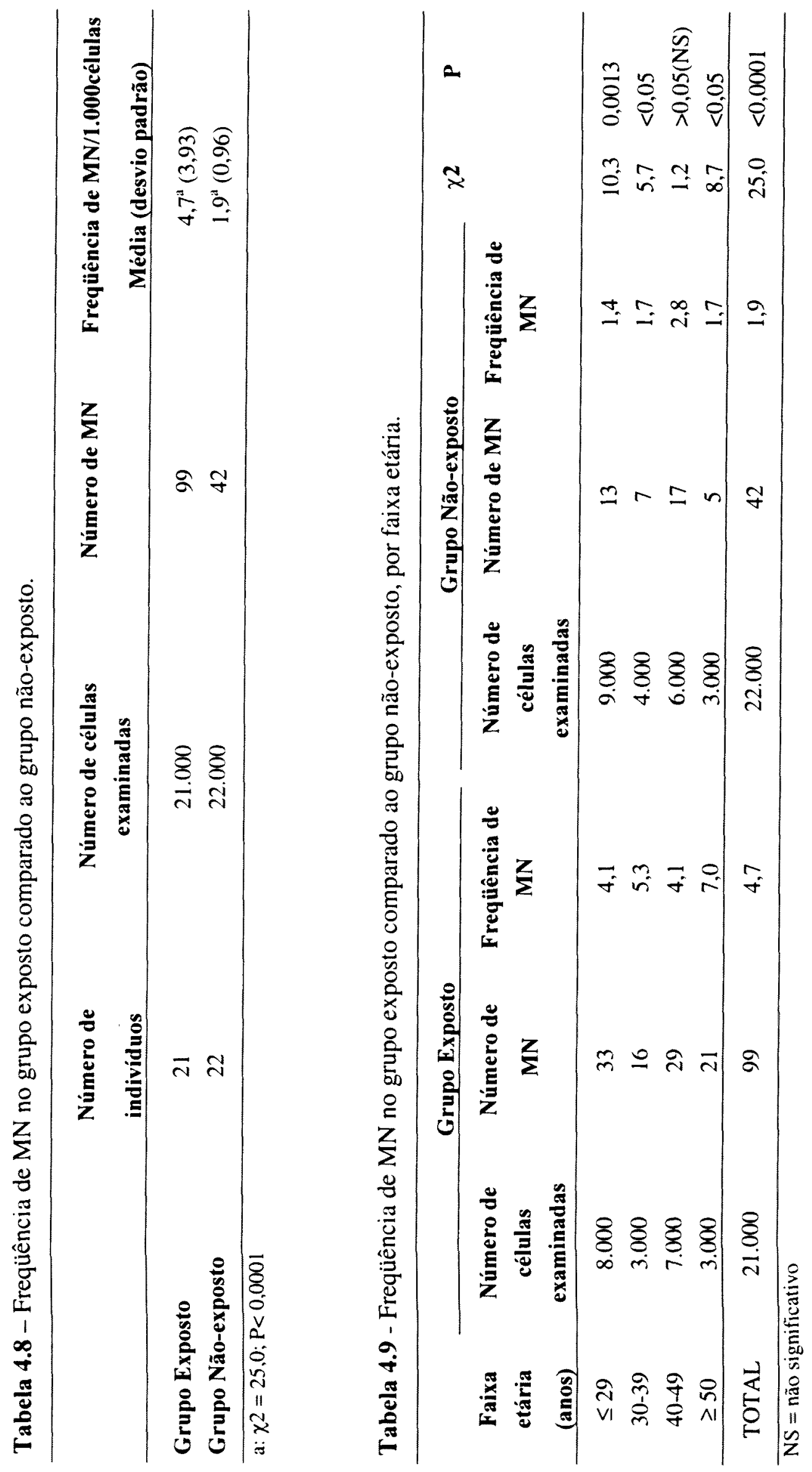




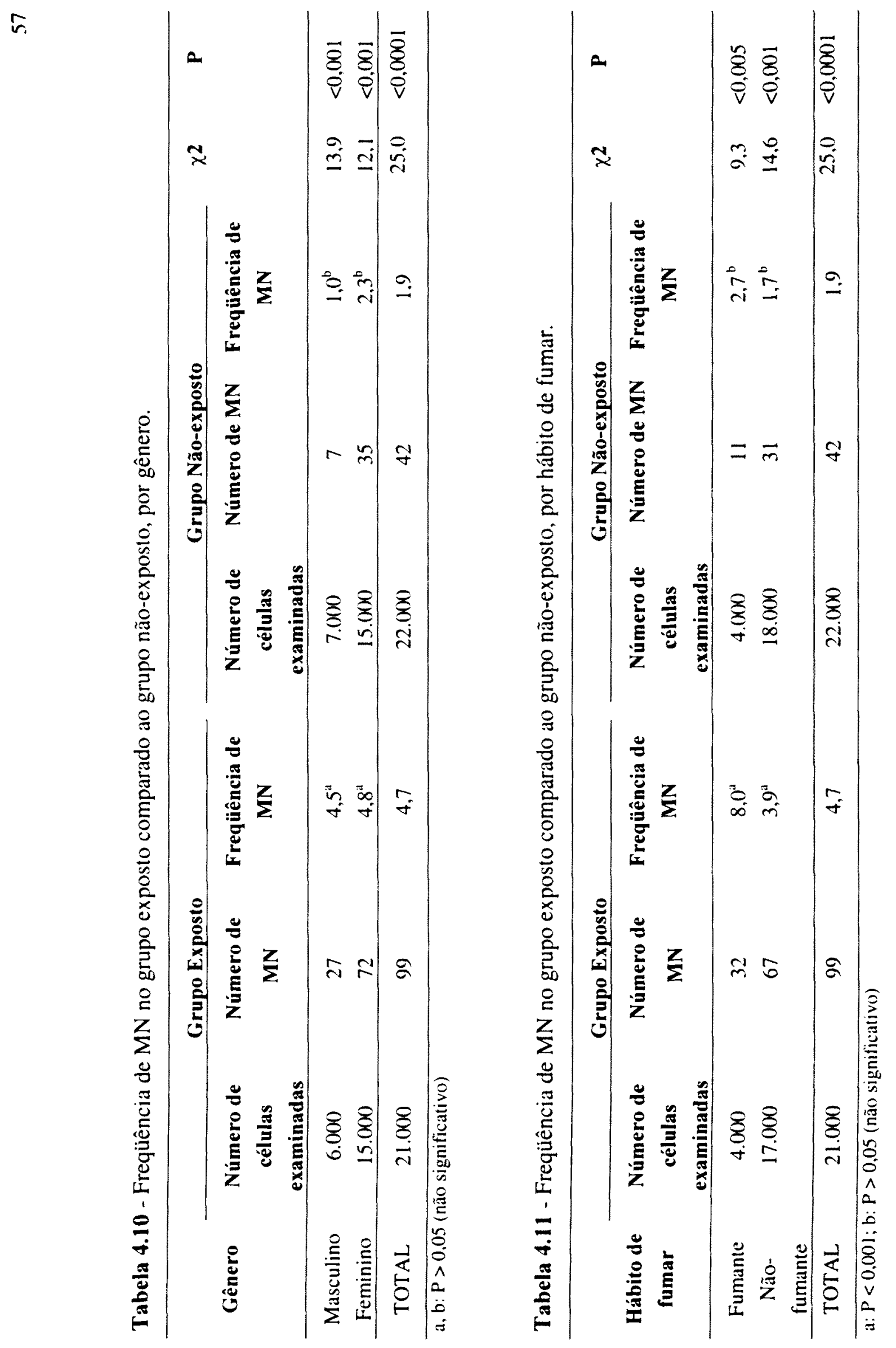


Tabela 4.12 - Frequiência de MN no grupo exposto por laboratório.

\begin{tabular}{cccc}
\hline Laboratório & $\begin{array}{c}\text { Número de células } \\
\text { examinadas }\end{array}$ & $\begin{array}{c}\text { Número de } \\
\text { MN }\end{array}$ & Freqüência de MN \\
\hline 1 & 8.000 & 34 & 4,3 \\
2 & 6.000 & 18 & $3,0^{\mathrm{a} . \mathrm{b}}$ \\
3 & 3.000 & 21 & $7,0^{\mathrm{a}}$ \\
4 & 4.000 & 26 & $6,5^{\mathrm{b}}$ \\
\hline TOTAL & 21.000 & 99 & 4,7 \\
\hline
\end{tabular}

a, b: $\mathrm{P}<0.05 ;$ para as demais associações $\mathrm{P}>0,05$ (não significativo)

Tabela 4.13 - Frequiência de MN no grupo exposto por função nos laboratórios.

\begin{tabular}{cccc}
\hline $\begin{array}{c}\text { Função no } \\
\text { laboratório }\end{array}$ & $\begin{array}{c}\text { Número de células } \\
\text { examinadas }\end{array}$ & $\begin{array}{c}\text { Número de } \\
\text { MN }\end{array}$ & Frequiência de MN \\
\hline Pesquisador & 7.000 & 41 & $5,9^{\mathrm{a} . \mathrm{b}}$ \\
Estagiário & 11.000 & 45 & $4,1^{\mathrm{a}}$ \\
Auxiliar & 3.000 & 13 & $4,3^{\mathrm{b}}$ \\
\hline TOTAL & 21.000 & 99 & 4,7 \\
\hline
\end{tabular}

$\mathrm{a}, \mathrm{b}: \mathrm{P}>0,05$ (não significativo) 


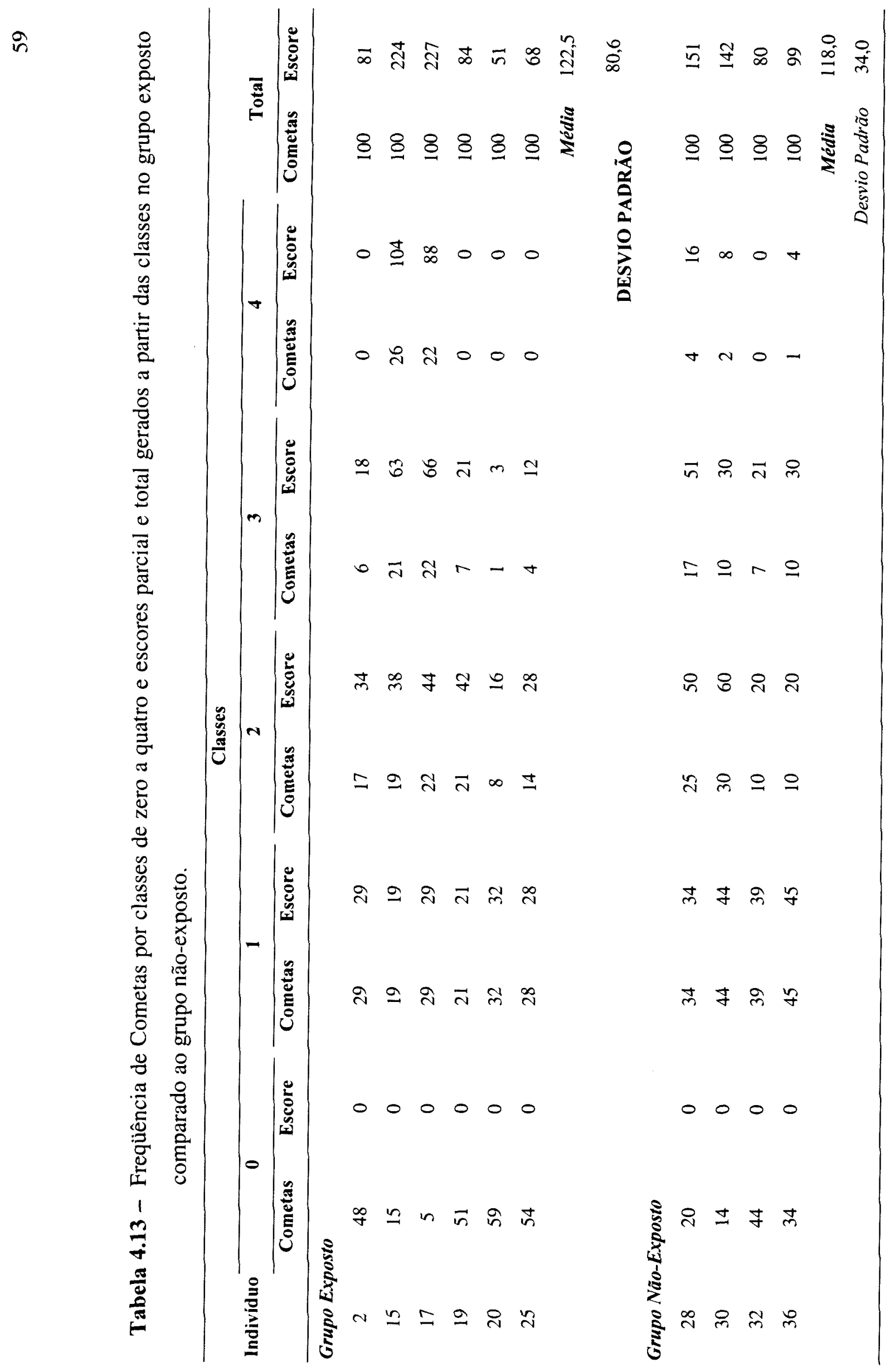


Tabela 4.14 - Frequêencia de MN e tempo de exposição para os indivíduos do grupo exposto.

\begin{tabular}{|c|c|c|}
\hline Indivíduo & Freqüência $M N / 1.000$ células & Tempo exposição (meses) \\
\hline 1 & 0 & 15 \\
\hline 2 & 1 & 17 \\
\hline 5 & 3 & 86 \\
\hline 6 & 4 & 111 \\
\hline 7 & 10 & 336 \\
\hline 8 & 4 & 117 \\
\hline 9 & 8 & 60 \\
\hline 10 & 4 & 240 \\
\hline 12 & 2 & 61 \\
\hline 13 & 7 & 180 \\
\hline 14 & 3 & 51 \\
\hline 15 & 3 & 192 \\
\hline 17 & 1 & 7 \\
\hline 18 & 2 & 19 \\
\hline 19 & 6 & 6 \\
\hline 20) & 12 & 36 \\
\hline 21 & 3 & 192 \\
\hline 23 & 7 & 336 \\
\hline 24 & 7 & 204 \\
\hline 25 & 10 & 132 \\
\hline 26 & 2 & 144 \\
\hline Média & 4,7 & 121 \\
\hline Desvio padrão & 3.93 & 102 \\
\hline
\end{tabular}




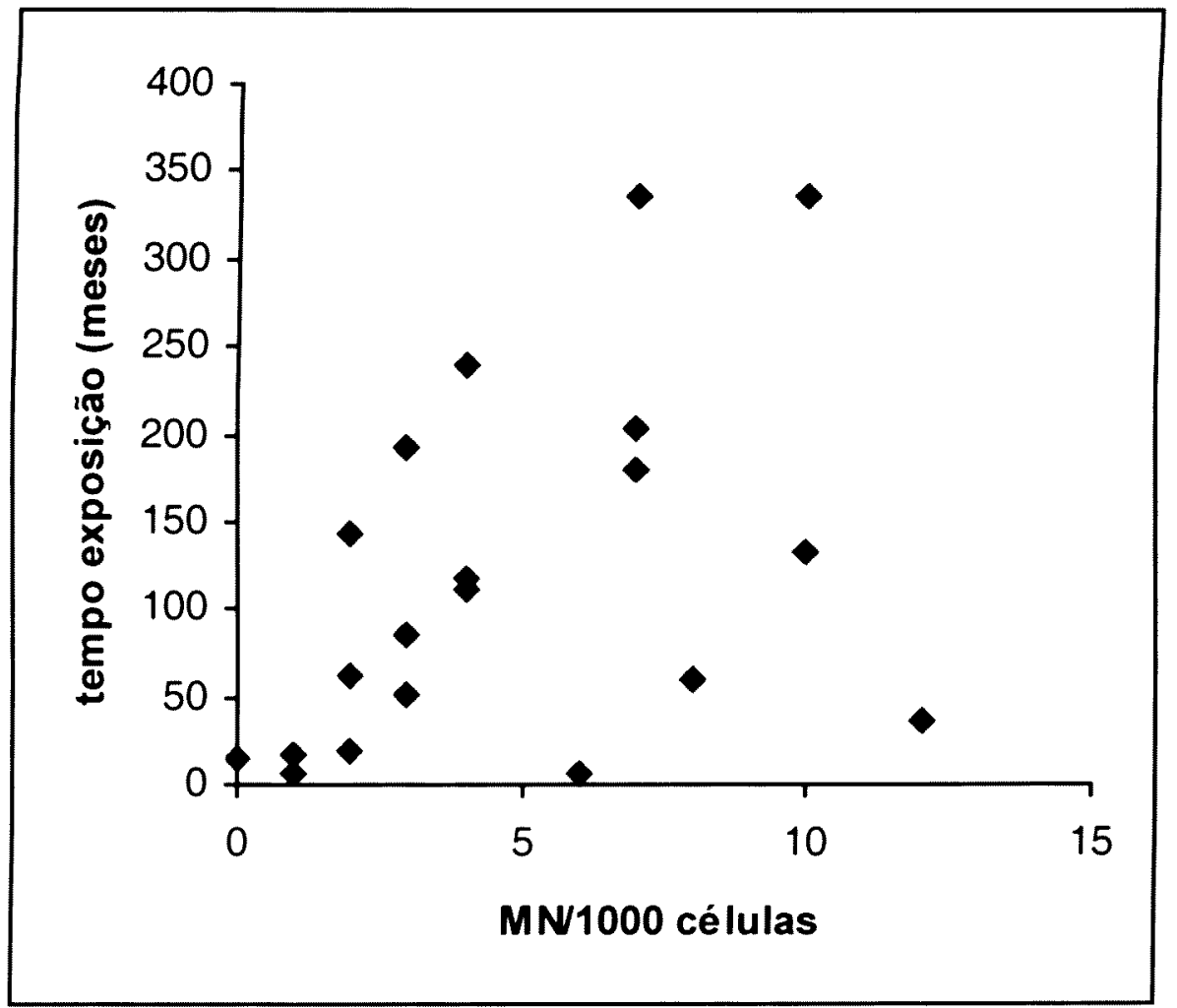

Figura 4.1 - Correlação entre frequiencia de $M N$ e tempo de exposição no grupo exposto. Coeficiente de Correlação de Pearson $=0,38$ (fraca correlação positiva).

Tabela 4.15 - Características da exposição obtidas a partir do questionário (Anexo V) aplicado ao grupo exposto.

\begin{tabular}{lccc}
\hline Função & $\begin{array}{c}\text { Tempo exposição* } \\
\text { (anos) }\end{array}$ & $\begin{array}{c}\text { Jornada trabalho* } \\
\text { (horas/semana) }\end{array}$ & $\begin{array}{c}\text { Exposição a solventes* }^{*} \\
\text { (horas/semana) }\end{array}$ \\
\hline Pesquisador & $232( \pm 91)$ & $40( \pm 0)$ & $25( \pm 9)$ \\
Estagiário & $55( \pm 73)$ & $23( \pm 9)$ & $20( \pm 11)$ \\
Auxiliar & $147( \pm 32)$ & $33( \pm 13)$ & $26( \pm 9)$
\end{tabular}

* Valores médios (desvio padrão) 
Tabela 4.16 - Resumo das informações obtidas a partir do questionário (Anexo VI) aplicado aos grupos exposto e não-exposto.

\begin{tabular}{|c|c|c|}
\hline Fator & Grupo Exposto & Grupo Não-Exposto \\
\hline Número Total Individuos & 21 & 22 \\
\hline \multicolumn{3}{|l|}{ Faixa Etária } \\
\hline$\leq 29$ anos & $8(39 \%)$ & $9(41 \%)$ \\
\hline 30-39 anos & $3(14 \%)$ & $4(18 \%)$ \\
\hline $40-49$ anos & $7(33 \%)$ & $6(27 \%)$ \\
\hline$\geq 50$ anos & $3(14 \%)$ & $3(14 \%)$ \\
\hline Idade média (anos) & $36,2( \pm 12,4)$ & $35,4( \pm 13,4)$ \\
\hline \multicolumn{3}{|l|}{ Gênero } \\
\hline Feminino & $15(71 \%)$ & $15(68 \%)$ \\
\hline Masculino & $6(29 \%)$ & $7(32 \%)$ \\
\hline \multicolumn{3}{|l|}{ Hábito de fumar } \\
\hline Não-fumantes & $17(81 \%)$ & $18(82 \%)$ \\
\hline Fumantes & $4(19 \%)$ & $4(18 \%)$ \\
\hline Média maços/semana & $5,6( \pm 1,7)$ & $4,5( \pm 1,7)$ \\
\hline Tempo exposição (anos) & $12,0( \pm 3,9)$ & $15,0( \pm 4,1)$ \\
\hline \multicolumn{3}{|l|}{ Local nascimento } \\
\hline Sudeste & $19(90 \%)$ & $19(86 \%)$ \\
\hline Nordeste & $2(10 \%)$ & $3(14 \%)$ \\
\hline \multicolumn{3}{|l|}{ Raça } \\
\hline Branca & $15(71 \%)$ & $17(77 \%)$ \\
\hline Negra & $4(19 \%)$ & $2(9 \%)$ \\
\hline Amarela & $2(10 \%)$ & $3(14 \%)$ \\
\hline \multicolumn{3}{|l|}{ Nivel escolaridade } \\
\hline Fundamental & $3(14 \%)$ & $5(23 \%)$ \\
\hline Médio & $1(5 \%)$ & $5(23 \%)$ \\
\hline Superior & $17(81 \%)$ & $12(55 \%)$ \\
\hline \multicolumn{3}{|l|}{ Cônjuge } \\
\hline Sim & $9(43 \%)$ & $10(45 \%)$ \\
\hline Não & $12(57 \%)$ & $12(55 \%)$ \\
\hline \multicolumn{3}{|l|}{ Filhos } \\
\hline Sim & $11(52 \%)$ & $8(36 \%)$ \\
\hline Nimero médio de filhos & 2 & 2 \\
\hline Não & $10(48 \%)$ & $14(64 \%)$ \\
\hline \multicolumn{3}{|l|}{ Efeitos reprodutivos } \\
\hline Malformação & $1(5 \%)$ & $0(0 \%)$ \\
\hline Aborto espontâneo & $0(0 \%)$ & $0(0 \%)$ \\
\hline Infertilidade & $0(0 \%)$ & $0(0 \%)$ \\
\hline \multicolumn{3}{|l|}{ Câncer na familia } \\
\hline $\operatorname{Sim}$ & $7 * *(33 \%)$ & $7(32 \%)$ \\
\hline Não & $14(67 \%)$ & $15(68 \%)$ \\
\hline
\end{tabular}


Tabela 4.15 (cont.) - Resumo das informações obtidas a partir do questionário (Anexo VI) aplicado aos grupos exposto e não-exposto.

\begin{tabular}{lcc}
\hline Medicamentos & $8^{*}(38 \%)$ & $10^{*}(45 \%)$ \\
Sim & $13(62 \%)$ & $22(55 \%)$ \\
Não & & \\
Reposiçäo hormonal & $2(13 \%)^{* * *}$ & $3(20 \%)^{* * *}$ \\
Sim & $13(87 \%)^{* * *}$ & $12(80 \%)^{* * *}$ \\
Não & & \\
Hábito de beber (álcool) & $13(62 \%)$ & $14(64 \%)$ \\
Sim & $73,8( \pm 79,7)$ & $82,0( \pm 71,1)$ \\
$\quad$ Volume médio (mL/semana) & $8(38 \%)$ & $8(36 \%)$ \\
Não & $21(100 \%)$ & $22(100 \%)$ \\
Alimentação & $20(95 \%)$ & $22(100 \%)$ \\
Cereais & $20(95 \%)$ & $22(100 \%)$ \\
Vegetais & $11(52 \%)$ & $16(73 \%)$ \\
Frutas & $19(90 \%)$ & $21(95 \%)$ \\
Peixe & $19(90 \%)$ & $22(100 \%)$ \\
Carne vermelha & $20(95 \%)$ & $21(95 \%)$ \\
Carne branca & $19(90 \%)$ & $20(91 \%)$ \\
Leite & $16(76 \%)$ & $16(73 \%)$ \\
Ovos & & $1(5 \%)$ \\
Doces & $0(0 \%)$ & $21(95 \%)$ \\
Vitaminas & $21(21 \%)$ & \\
Sim & & \\
Não &
\end{tabular}

* Medicamentos usados (ambos os grupos): contraceptivos, analgésicos, antiinflamatórios.

** 1 caso de câncer (mama) no próprio trabalhador.

*** Somente gênero feminino. 


\section{DISCUSSÃO}

A estratégia de amostragem descrita em 4.1.2 foi elaborada de acordo com os dados coletados na Visita Preliminar e considerando-se que:

- as substâncias a serem analisadas seriam solventes orgânicos e estariam presentes em grande número ao mesmo tempo;

- o período de coleta seria relativamente longo;

- a ventilação nos laboratórios onde seriam realizadas as amostragens era adequada;

- os equipamentos a serem utilizados na coleta necessitavam ser comprados e o recurso para custear as análises era limitado.

Assim, optou-se por amostragem passiva em lugar de amostragem ativa, uma vez que o custo desta última (bomba portátil e tubos coletores) seria muito superior ao da primeira (amostradores passivos ou dosímetros). Além disso, ventilações inadequadas que poderiam interferir na amostragem passiva não foram observadas nos laboratórios durante a visita preliminar.

As atividades envolvendo solventes orgânicos desenvolvidas pelos trabalhadores, embora não apresentassem freqüência regular na maioria dos laboratórios, quando eram desenvolvidas ocupavam praticamente toda a carga horária diária dos trabalhadores de modo uniforme. Por este motivo decidiu-se por amostras únicas por todo o período de trabalho.

Como o interesse maior era a proteção do trabalhador, foi dada a preferência por amostragem pessoal e não a de ponto fixo.

Foram considerados três grupos homogêneos de risco: pesquisadores, estagiários e auxiliares. Embora pertencessem a diferentes laboratórios, não era posível identificar dentro destes 3 grupos, sem auxílio de instrumentos, indivíduos com maior ou menor risco de exposição ocupacional. De 
acordo com as observações descritas em 4.1.1 e os dados mostrados na Tabela 4.1, as atividades envolvendo solventes nos laboratórios eram realizadas em sua maioria pelos estagiários, nos quais foram realizadas 8 coletas ambientais. Os pesquisadores dividiam seu tempo de trabalho entre atividades técnicas no laboratório envolvendo solventes e outras atividades (por exemplo, administrativas e pesquisa teórica) não relacionadas à exposição a solventes. Porém, em tempos anteriores, exerciam as atividades hoje desenvolvidas pelos estagiários. Desta função (pesquisador) foram coletadas 4 amostras ambientais. Os auxiliares desempenhavam principalmente atividades de descarte e lavagem dos materiais utilizados nas análises realizadas nos laboratórios, inclusive aquelas envolvendo solventes orgânicos. Foram coletadas 2 amostras ambientais da função auxiliar.

Para todos os 3 grupos homogêneos, o tempo de exposição aos solventes, o número e os tipos de solventes orgânicos aos quais os trabalhadores estavam expostos variavam em função do trabalho realizado nestes laboratórios, ou seja, pesquisa e prestação de serviços, neste último caso dependente da demanda solicitada. Por outro lado, como esta variação era semelhante em todos os laboratórios e a principal diferença nas exposições era dada pela função que cada trabalhador exercia, os grupos foram considerados homogênos quanto ao risco pela função que exerciam: pesquisador, estagiário e auxiliar.

O número total de amostras coletadas foi considerado adequado para a estimativa qualitativa e quantitativa das exposições a solventes nas 3 funções (pesquisador, estagiário, auxiliar), uma vez que os resultados das análises realizadas nestas amostras (Tabela 4.2) demonstraram concordância. Um maior número de amostras e replicatas seriam coletadas e analisadas somente em caso de resultados discordantes entre si (grandes diferenças nas concentrações ambientais) por motivos de recursos financeiros limitados.

Os resultados mostrados na Tabela 4.2 revelam exposições a diversos solventes orgânicos concomitantemente (em média, presença de 5 solventes/amostra), porém, geralmente em baixas concentrações. 
Os principais solventes encontrados nas 14 amostras analisadas foram:

- etanol (11 amostras);

- acetona (10 amostras);

- acetonitrila (9 amostras);

- acetato de etila ( 8 amostras);

- tolueno (8 amostras);

- diclorometano (7 amostras);

- benzeno ( 5 amostras);

- clorofórmio (3 amostras).

Os somatórios dos Índices de Exposição para os efeitos críticos (base do TLV) calculados e apresentados na Tabela 4.3 demonstram valores geralmente abaixo de 0,5 (Nível de Ação), exceto para Benzeno acima do Nível de Ação e abaixo do Limite de Exposição na amostra 10; e para Clorofórmio, bem acima do Limite de Exposição nas amostras 10, 11 e 12.

Entre todos os solventes encontrados, 3 são classificados como carcinogênicos $(A C G I H-2002)$ :

- Benzeno: classe Al - carcinogênico confirmado para o homem;

- Clorofórmio: classe A3 - carcinogênico confirmado para animais;

- Diclorometano: classe A3 - carcinogênico confirmado para animais.

As médias geométricas das concentrações ambientais encontradas para os solventes acima mostram valores abaixo dos TLVs-TWA (Limites de Exposição de Concentração Média Ponderada pelo Tempo) para Benzeno e Diclorometano; e valores acima do $T L V-T W A$ para Clorofórmio (Tabelas 4.4 a 4.6$)$.

Vale lembrar que estes limites (TLVs-TWA) são estabelecidos com base no efeito crítico câncer somente para o Benzeno. Para os solventes 
Clorofórmio e Diclorometano, os limites têm como base os efeitos ou sítios críticos figado/reprodutivo e anóxia/SNC, respectivamente.

Portanto, para o solvente Diclorometano, concentrações abaixo do TLV-TWA representam condições seguras tomando por base efeito/sítio críticos anóxia/SNC e não o efeito carcinogênico.

Para o solvente Clorofórmio, encontramos uma situação de exposição acima do $T L V$-TWA. A mesma observação acima para Diclorometano pode ser considerada para o Clorofórmio. Porém, neste caso, mesmo tomando por base o efeito/sítio críticos o fígado e o sistema reprodutivo, a exposição é considerada excessiva.

As 3 amostras ambientais nas quais foram encontradas concentraçōes de Clorofórmio acima dos Limites de Exposição foram coletadas a partir das mesmas funções, atividades e laboratório. O laboratório apresentava capela e exaustor em funcionamento no momento em que as amostras foram coletadas. Porém, as atividades eram realizadas somente em parte dentro da capela.

Dos testes citogenéticos realizados, somente o Micronúcleo apresentou resultados satisfatórios. Problemas na técnica do teste do Cometa impediram a leitura microscópica da maioria das lâminas (amostras) por apresentarem escassez e degeneração das células. Uma única amostra de sangue foi coletada por indivíduo para a realização de ambos os testes, MN e Cometa. A retirada da camada de leucócitos foi realizada primeiramente para o teste do $\mathrm{MN}$, restando, provavelmente, uma quantidade muito reduzida destas células para o teste do Cometa. A degeneração das células foi possivelmente ocasionada por problemas com o tampão de eletroforese e a corrente aplicada na eletroforese. Foi também levantada a possibilidade de que a degeneração celular tivesse sido ocasionada por problemas com o anticoagulante Liquemine ${ }^{\circledR}$, porém, como o efeito não foi observado nas lâminas para $\mathrm{MN}$, esta hipótese foi descartada. Assim, somente 10 amostras ( 6 expostos e 4 não-expostos) puderam ser examinadas, sendo insuficientes 
para a aplicação de testes estatísticos e/ou alguma análise conclusiva. Os resultados apresentados na Tabela 4.13 mostram valores (médias) de freqüência de cometas entre expostos e não-expostos aparentemente bastante próximos.

Um aumento significativo foi encontrado na frequiência de $\mathrm{MN}$ do grupo exposto $(4,7 \mathrm{MN} / 1.000$ células binucleadas) quando comparado ao grupo não-exposto (1,9MN/1.000 células binucleadas), calculado através do teste do Quiquadrado com correção de Yates $(\chi 2=25,0$; grau de liberdade $=1 ; \mathrm{P}<0,0001)$, conforme dados da Tabela 4.8 .

Estes resultados estão em concordância com aqueles encontrados em um estudo realizado na Itália por TESTA et al. (2002), que observaram um aumento significativo na freqüência de MN em 50 trabalhadores de laboratórios quando comparados a 53 indivíduos controles. Por outro lado, discordam dos resultados de NAROD et al. (1988) que avaliaram trabalhadores de um laboratório de pesquisas no Canadá através dos testes do MN e Troca de Cromátides Irmãs (TCI), não encontrando diferenças significativas quando comparados aos indivíduos controles.

De acordo com o "Human Micronucleous Project", um estudo colaborativo internacional que tem como objetivo maior coletar dados das frequiências de $\mathrm{MN}$ em diferentes populações humanas,os principais fatores que afetam as freqüências de $\mathrm{MN}$ são provenientes de 4 fontes fundamentais:

- fatores relacionados aos indivíduos, como idade, gênero, etnia, etc.;

- exposição a agentes genotóxicos;

- parâmetros metodológicos;

- critérios para identificação de células binucleadas e de MN.

Com a finalidade de reduzir a influência de fatores relacionados aos indivíduos, foi realizado um pareamento dos indivíduos do grupo exposto com os do grupo não-exposto em relação a idade, gênero e hábito de fumar. Além disso, uma avaliação feita por meio dos questionários aplicados a ambos os 
grupos (exposto e não-exposto) e resumida na Tabela 4.16, contemplando os vários fatores individuais que podem influenciar na frequiência de $\mathrm{MN}$, tais como etnia, alimentação, hábitos de fumar e beber, uso de medicamentos e vitaminas, entre outros, nos permitiu inferir semelhança entre os dois grupos.

Estudos colaborativos recentes (SURRALLÉS e
NATARAJAN 1997; BONASSI et al. 2001) têm levantado a questão da heterogeneidade dos protocolos utilizados para as metodologias nos testes do MN, assim como para os critérios de identificação de células binucleadas e de $\mathrm{MN}$, e as análises estatísticas aplicadas, nos diversos laboratórios que utilizam este teste. Esforços no sentido de padronizar tais protocolos vêm sendo realizados por estes estudos, permitindo uma melhor comparação entre os resultados dos diversos trabalhos publicados.

Os dados das Tableas 4.9 a 4.11 mostram que as diferenças nas freqüências de $\mathrm{MN}$ entre os grupos exposto e não-exposto permaneceram significativas, mesmo quando estes são estratificados por gênero, hábito de fumar e faixa etária, com exceção da faixa etária de 40-49 anos. Neste último caso, embora tenha sido observada uma maior frequêencia de $\mathrm{MN}$ no grupo exposto, a diferença não foi significativa $(P>0,05)$.

Ainda nas mesmas Tabelas, podem ser observadas diferenças nas freqüências de $\mathrm{MN}$ quando se comparam, dentro do mesmo grupo, diferentes faixas etárias, gêneros e hábitos de fumar, embora em grande parte não significativas. Estes resultados estão em concordância com dados da literatura (FENECH et al. 1994; FENECH et al. 1997; BONASSI et al. 2001) que têm mostrado maiores freqüências de $\mathrm{MN}$ em mulheres quando comparadas a homens, em fumantes quando comparadas a não-fumantes, e uma correlação positiva entre frequiência de $\mathrm{MN}$ e idade.

No caso específico da idade, uma correlação positiva entre este fator e frequência de $\mathrm{MN}$ foi observada nos nossos resultados para a maioria das 
faixas etárias, excetuando-se as faixas de 40-49 anos para o grupo exposto e de $\geq 50$ anos para o grupo não-exposto. De acordo com BONASSI et al. (2001), a influência da idade sobre a frequiência de $\mathrm{MN}$ pode ser observada principalmente após os 40 anos. Um aumento do tamanho da amostra provavelmente evidenciaria melhor esta correlação.

Nas Tabelas 4.12 e 4.13 observam-se os valores de frequiências de MN comparando-se os diferentes laboratórios e as diferentes funções nos laboratórios. As diferenças foram significativas quando se compararam o Laboratório 2 que apresentou a menor freqüência de $M N$ com os Laboratórios 3 e 4 que apresentaram as maiores frequiências. De acordo com os resultados das análises ambientais (Tabela 4.2) o Laboratório 3 foi o único onde se observou Índices de Exposição $>1$, para o solvente Clorofórmio em todas as 3 amostras analisadas, e Índice de Exposição $>0,5$ para o solvente Benzeno em 1 amostra analisada. As frequêencias de $\mathrm{MN}$ mais elevadas no Laboratório 4 podem ter sido influenciadas pelo fator hábito de fumar, uma vez que 2 dos 4 funcionários neste Laboratório eram fumantes e uma diferença significativa $(P<0,001)$ foi observada entre expostos fumantes e não-fumantes.

As diferenças nas frequêencias de $\mathrm{MN}$ observadas entre as diferentes funções nos laboratórios (pesquisador, estagiário, auxiliar) não foram significativas $(\mathrm{P}>0,05)$.

A Tabela 4.15 mostra uma comparação entre os diferentes grupos (funçōes) de expostos avaliados quanto ao tempo de exposição em anos, jornada de trabalho semanal e tempo estimado de exposição semanal, de acordo com as respostas obtidas no questionário (Anexo V) formulado para avaliar questões ocupacionais. Pode ser observado que os pesquisadores apresentam um maior tempo de exposição em anos, seguidos pelos auxiliares, enquanto os estagiários têm um menor tempo na função. Embora as jornadas de trabalho semanais apresentem variações para as diferentes funções, o tempo estimado pelos trabalhadores de exposição semanal a solventes mostrou-se bastante semelhante. 
A possível correlação entre a exposição a solventes orgânicos nos trabalhadores de laboratórios e danos genotóxicos, foi avaliada através do cálculo do coeficiente de correlação de Pearson, utilizando-se como parâmetro da exposição ocupacional o tempo de exposição preferencialmente às concentrações de solventes analisadas nas amostras ambientais, uma vez que estas últimas estavam em sua maioria abaixo dos níveis de ação.

O coeficiente de correlação de Pearson calculado para tempo de exposição (meses) e frequiência de $\mathrm{MN}$ foi de $+0,38$, indicando uma fraca correlação positiva. O gráfico de correlação é mostrado na Figura 4.1. Quando o cálculo é realizado somente para os expostos não-fumantes, o coeficiente de correlação de Pearson é de $+0,58$, indicando uma forte correlação positiva. Os pontos correspondentes aos indivíduos fumantes (Tabela 4.14 e Figura 4.1) contribuem para uma maior dispersão em relação à reta, uma vez apresentarem alta freqüência de $\mathrm{MN}$ com pouco tempo de exposição.

Um aumento nas freqüências de $\mathrm{MN}$ em função do tempo de exposição ocupacional em anos tem sido observado em alguns estudos (PITARQUE et al. 2002: ANWAR et al. 1994; NISE et al. 1991).

De acordo com SAVAGE (2000), a exposição crônica a agentes clastogênicos pode conduzir a uma persistência das moléculas e/ou das lesões nas células alvo, produzindo alterações nestas células e nas gerações de células subsequentes. Os processos de reparo passam a ficar continuamente ocupados enquanto as células tentam se adaptar e, portanto, os efeitos podem se acumular.

As altas frequiências de $\mathrm{MN}$ no grupo exposto comparado ao grupo não-exposto observadas mesmo com exposições a solventes consideradas baixas (Índices Exposição $<0,5 \mathrm{em}$ sua maioria) pode indicar uma incerteza da segurança dos Limites de Exposição atualmente recomendados quando se trata de efeitos genotóxicos. Conforme citado anteriormente, para alguns solventes 
considerados carcinogênicos (Clorofórmio e Diclorometano), estes limites são baseados em outros efeitos que não o carcinogênico. Além disso, a contribuição dos outros solventes não classificados como carcinogênicos em termos de interações sinérgicos ou de potenciação para os efeitos em questão é pouco conhecida. No caso específico deste estudo, os trabalhadores manipulavam outros grupos de substâncias químicas com potencial genotóxico (pesticidas, aflatoxinas), as quais poderiam estar contribuindo para a freqüência de MN observada.

A associação entre exposição a solventes orgânicos em trabalhadores de laboratórios e outras atividades ocupacionais e dano genotóxico avaliado através do Teste do Micronúcleo vem sendo observada em alguns estudos (TESTA et al. 2002; PITARQUE et al. 2002; PINTO et al. 2000; NILSSON et al. 1997; SILVA AUGUSTO et al. 1997), porém, resultados negativos também são relatados (PITARQUE et al 1996; HAGMAR et al 1989; NAROD et al. 1988). Os resultados conflitantes podem ser atribuídos à complexidade das exposições (PITARQUE et al 1996), à baixa precisão dos testes citogenéticos, ou ainda, ao problema da identificação do parâmetro mais relevante da exposição (HAGMAR et al. 1989).

Os estudos colaborativos interancionais como o "Human Micronucleus Project" já citado nesta discussão, têm como objetivos, entre outros, determinar a validade do teste do MN avaliado como freqüência de $\mathrm{MN}$ em células binucleadas, como um biomarcador de exposição e de risco de câncer e outras doenças crônicas.

Atualmente, o teste do $\mathrm{MN}$ é usado para avaliar a presença e extensão de dano cromossômico (resultante de quebra ou perda) em populações ocupacionais expostas a agentes genotóxicos, sendo, portanto, considerado um “indicador biológico de efeitos precoces" (TESTA et al. 2002). A avaliação acima deve ser feita em grupos de indivíduos e não com base individual. 
Por outro lado, a utilização da frequêencia de $\mathrm{MN}$ como preditivo do risco de câncer ou outras doenças crônicas permanece em processo de avaliação. Neste caso, outros testes citogenéticos como a frequiência de aberrações cromossômicas, embora seja mais complexa e consuma mais tempo para análise, é considerada adequada para avaliar risco de câncer (TESTA et al. 2002).

Os resultados aqui apresentados mostram um aumento significativo de danos genéticos em termos de frequiência de $\mathrm{MN}$ no grupo exposto quando comparado ao grupo não-exposto, indicando que estes efeitos podem ser desenvolvidos mesmo em situações de baixas exposições a solventes orgânicos nos laboratórios conforme medido através das avaliações ambientais, ressaltando a importância da monitorização biológica nas exposições a agentes genotóxicos e a necessidade de repensar as exposições de trabalhadores de laboratórios consideradas "baixas" e até então, "seguras". 


\section{CONCLUSÕES}

Os resultados obtidos no presente trabalho nos permitiram chegar às seguintes conclusões:

a. Os trabalhadores de laboratórios avaliados estavam expostos a uma diversidade de solventes orgânicos concomitantemente, em média 5 diferentes solventes por amostra analisada;

b. Do ponto de vista qualitativo, os principais solventes encontrados foram etanol, acetona, acetonitrila, acetato de etila, tolueno, diclorometano, benzeno, clorofórmio (em ordem de número de vezes que apareceram nas amostras ambientais);

c. Os Índices de Exposição para os solventes encontrados e os somatórios dos Índices de Exposição com base nos efeitos críticos estavam em sua maioria abaixo do Nível de Ação (0,5);

d. As exceções ao item c foram: Índice de Exposição acima do Nível de Ação e abaixo do Limite de Exposição para Benzeno em uma amostra; Índice de Exposição acima do Limite de Exposição para Clorofórmio em três amostras;

e. Foram encontrados três solventes orgânicos classificados como carcinogênicos nas amostras ambientais: Benzeno (A1), Clorofórmio (A3) e Diclorometano (A3);

f. Um aumento significativo foi encontrado na frequêencia de $\mathrm{MN}$ do grupo exposto (4,7MN/1.000 células binucleadas) quando comparado ao grupo não-exposto (1,9MN/1.000 células binucleadas), calculado através do teste do Qui-quadrado com correção de Yates $(\chi 2=25,0$; grau de liberdade $=1 ; \mathrm{P}<0,0001)$, indicando aumento de dano genético no grupo exposto;

g. Maiores frequiências de $\mathrm{MN}$ foram encontradas nos indivíduos expostos fumantes quando comparados aos expostos não-fumantes ( $\mathrm{P}<0,001)$;

h. Uma fraca correlação positiva (Coeficiente de Correlação de Pearson $=0,38$ ) foi encontrada entre tempo de exposição ocupacional a solventes em laboratórios e freqüência de $\mathrm{MN}$. 


\section{RECOMENDAÇÕES}

- Estender o estudo para um número maior de trabalhadores de laboratórios para possibilitar melhores avaliação estatística e conclusões;

- Ampliar o estudo quanto aos testes citogenéticos, acrescentando testes que avaliam outros danos cromossômicos, além de quebras e perdas como avaliado pelo teste do $\mathrm{MN}$;

- Reavaliar e melhorar o protocolo de coleta e execução do teste do Cometa, a fim de se evitar perda e degeneração de celulares;

- Melhorar as condições de exposição nos laboratórios avaliados (e nos laboratórios de modo geral) através das seguintes medidas:

- estudar a possibilidade de substituição dos solventes classificados como carcinogênicos (A1 e A3, no caso específico dos laboratórios avaliados);

- avaliar o funcioanamento das capelas e exaustores;

- executar todas as atividades com solventes dentro das capelas;

- usar luvas adequadas.

- Reavaliar os Limites de Exposição Ocupacionais, considerando os efeitos genotóxicos e as interações entre os agentes tóxicos nas exposições mistas;

- Incluir nos exames médicos periódicos de trabalhadores expostos a agentes genotóxicos o Teste do MN, uma vez se tratar de um "Indicador Biológico de Efeito Precoce" de execução simples e relativamente rápida. 


\section{REFERÊNCIAS BIBLIOGRÁFICAS}

Aitio A. Biological monitoring today and tomorrow. Scand J Work Environ Health 1994; $20: 46-58$.

Anwar W, Salama SI, Serafy MME, Hemida SA, Hafez A. Chromosomal aberrations and micronucleus frequency in nurses occupationally exposed to cytotoxic drugs. Mutagenesis 1994, 9(4): 315-7.

Axelsson G, Lutz C, Rylander R. Exposure to solvents andoutcome of pregnancy in university laboratory employees. Br J Ind Med 1984; 41: 305-12.

Axelsson G, Rylander R. Outcome of pregnancy in women engaged in laboratory work at a petrochemical plant. Am J Ind Med 1989; 16: 539-45.

Babich H. Reproductive and carcinogenic health risks to hospital personnel from chemical exposure - a literature review. J Environ Health 1985; 48(2): 52-6.

Band PR, Le ND, Fang R, Deschamps M, Gallagher RP, Yang P. Identifiation of occupational cancer risks in British Columbia. A population-based case-control study of 1995 incident breast cancer cases by menopausal status, controllling for confounding factors. J Occup Environ Med 2000; 42(3): 284-310.

Belli S, Comba P, De Santis M, Grignoli M, Sasco AJ. Mortality study of workers employed by the Italian National Institute of Health, 1960-1989. Scand J Work Environ Health 1992; 18: 64-7.

Blomqvist U, Ericson A, Kallen B, Westerholm P. Delivery outcome for women in the pulp and paper industry. Scand J Work Environ Health 1981; 7: 114-18.

Bonassi S, Fenech M, Lando C, Lin Y-P, Ceppi M, Chana WP, Holland N, KirschColders M, Zeiger E, Ban S, Barale R, Bigatti MP, Bolognesi C, Jia C, Di Giorio M, 
Ferguson LR, Fucic A, Lima OG, Hrelia P, Krishnaka AP, Lee T-K, Migliore L, Mikhalevich L, Mirkova E, Mosesso P, Müller W-U, Odagiri Y, Scarfi MR, Szabova E, Vorobtsova I, Vral A, Zijno A. Human Micronucleous Project: international database comparison for results with the cytokinesis-block micronucleous assay in human lymphocytes: I. Effect of laboratory protocol, scoring criteria, and host factors on the frequency of micronuclei. Environ Mol Mutagen 2001; 37:31-45.

Brown TP, Paulson J, Panett B, Coupland C, Coggon D, Chilvers CED, Sasco AJ. Mortality pattern among biological research laboratory workers. Br J Cancer 1996; 73: $1152-5$.

Buesching WJ, Neff JC, Sharma HM. Infectious hazards in the clinical laboratory: a program to protect laboratory personnel. Clin Lab Med 1989; 9(2): 351-61.

Burnett C, Robinson C, Walker J. Cancer mortality in health and science technicians. Am J Ind Med 1999, 36: 155-8.

Carpenter L, Beral V, Roman E, Swerdlow AJ, Davies G. Cancer in laboratory workers (letter). Lancet 1991; 338: 1080-1.

Chang HY, Lin YM, Hsu PC, Guo YL. Reduction of sperm motility in a male laboratory worker exposed to solvents: a case study. Environ Health Perspect 2001; 109(7): 753-6.

Collins AR, Ai-Guo M, Duthie SJ. The kinetics of repair of oxidative DNA damage (strand breaks and oxidised pyrimidines) in human cells. Mutat Res 1995; 336: 6977.

Countryman RI, Heddle JÁ. The production of micronuclei from chromosome aberrations in irradiated cultures of human lymphocytes. Mutat Res 1976, 41: 321 32. 
Cordier S. Risk of cancer among laboratory workers (letter). Lancet 1990; 335 : 1097.

Cordier S, Goujard J. Expositions professionnelles à des substances chimiques et anomalies congénitales; état des connaissances. Rev Epidém et Santé Publ 1994; 42: $144-59$.

Cordier S, Mousel ML, Le Goaster C, Gachelin G, le Moual N, Mandereau L, Carrat F, Michaud G, Hemon D. Cancer risk among workers in biomedical research. Scand J Work Environ Health 1995: 21: 450-9.

Daly L, Herity B, Bourke GJ. An investigation of brain tumours and other malignancies in na gricultural research institute. Occup Environ Med 1994; 51 : 295-8.

Dosemeci M, Alavanja M, Vetter R, Eaton B, Blair A. Mortality among laboratory workers employed at the US Department of Agriculture. Epidemiology 1992; 3: 258-62.

Ericson A. Kallen B. Meirik O, Westerholm P. Gastrointestinal atresia and maternal occupation during pregnancy. J Occup Med 1982; 24: 515-18.

Ericson A, Eriksson M, Kallen B, Westerholm P, Zetterstrom R. Delivery outcome of women working in laboratories during pregnancy. Arch Environ Health 1984; 39: $5-10$.

Evans JH. Historical perspectives on the development of the in vitro micronucleous test: a personal view. Mutat Res 1997: 392: 5-10.

Fenech M. The cytokinesis-block micronucleus technique: a detailed description of the method and its application to genotoxicity studies in human populations. Mutat Res 1993: 285: 35-44. 
Fenech M, Morley AA. Measurement of micronuclei in human lymphocytes. Mutat Res 1985a, 148: 29-36.

Fenech M, Morley AA. The efect of donor age on spontaneous and induced micronuclei. muta. Mutat Res 1985b, 148: 99-105.

Fenech M. Neville S, Rinaldi J. Sex is an important variable affecting spontaneous microcucleus frequency in cytokinesis-blocked lymphocytes. Mutat Res 1994; 313 : 203-7.

Fenech M, Holland N, Chang WP, Zeiger E, Bonassi S. The Human Micronucleus Project - An international collaborative study on the use of the micronucleus technique for measuring DNA damage in humans. Mutat Res 428: 271-83.

Gattás GJ, Cardoso LA, Medrado-Faria MA, Saldanha PH. Frequency of oral mucosa micronuclei in gas station operators after introducing methanol. Occup Med 2001; 51(2): 107-13.

Gustavsson P. Reuterwall C, Sadigh J, Söderholm M. Mortality and cancer incidence among laboratory technicians in medical research and routine laboratories (Sweden). Cancer Causes Control 1999; 10: 59-64.

Hagmar L, Högstedt B, Welinder H, Karlsson A, Rassner F. Cytogenetic and hematological effects in plastic workers exposed to styrene. Scand J Work Environ Health $1989 ; 15: 136-41$.

Hagmar L, Bonassi S, Strönberg U, Mikoczy Z, Lando C, hansteen I-L, Montagud AH, Knudsen L, Norppa H, Reuterwall C, Tinnerberg H, Brogger A, Forni A, Högstedt B, Lambert B, Mitelman F, Nordenson I; Salomaa S, Skerfving S. Cancer predictive value of cytogenetic markers used in occupational health surveillance 
programs: a report from na ongoing study by the European Study Group on Cytogenetic Biomarkers and Health. Mutat Res 1998; 405: 171-8.

Hansen J. Breast cancer risk among relatively young women employed in solventusing industries. Am J Ind Med 1999; 36: 43-7.

Hansson E, Jansa S, Wanda H, Källen B, Östlund E. Pregnancy outcome for women working in laboratories in some of the pharmaceutical industries in Sweden. Scand $\mathbf{J}$ Work Environ Health 1980; 6:131-4.

Heidam LZ. Spontaneous abortions among laboratory workers: a follow up study. $\mathbf{J}$ Epidem Comm Health 1984; 38: 36-41.

[IARC] International Agency for Research on Cancer. Handling chemical carcinogens in the laboratory: problems of safety. Lyon; 1979. (IARC Scientific Publications $n^{\circ} 33$ ).

Lazarov D, Waldron HA, Pejin D. Acute myeloid leukaemia and exposure to organic solvents - a case-control study. Eur J Epidemiol 2000; 16(3): 295-301.

Lindbohm, M-L. Effects of parental exposure to solvents on pregnancy outcome. J Occup Environ Med 1995; 37(8): 908-14.

Lindbohm M-L. Women's reproductive health; some recent developments in occupational epidemiology. Am J Ind Med 1999; 36: 18-24.

Lindbohm M-L, Hemminki K, Bonhomme MG, Anttila A, Rantala K, Heikkilä P, Rosenberg MJ. Effects of paternal occupational exposure on spontaneous abortions. Am J Public Health 1991; 81: 1029-33.

Lipscomb JÁ, Fenster L, Wrensch M, Shusterma D, Swan S. Pregnancy outcomes in women potencially exposed to occupational solvents and women working in the electronics industry. J Occup Med 1991; 33(5): 597-604. 
Lohman PHM, Jansen JD, Baan RA. Comparison of various methodologies with respect to specificity and sensitivity in biomonitoring occupational exposure to mutagens and carcinogens. In: International Agency for Research on Cancer. Monitoring human exposure to carcinogenic and mutagenic agents. Lyon; 1984. (IARC Scientific Publications $n^{\circ} 59$ ).

Meirik O, Kallen B, Gauffin U, Erixson A. Major malformations in infants born of women who worked in laboratories while pregnant. Lancet 1979; i: 91.

Miligi L, Constantini AS, Crosignani P, Fontana A, Masala G, Nanni O, Ramazzotti V, Rodella S, Sagnaro E. Tumino R, Viganò C, Vindigni C, Vineis P. occupational, environmental, and life-style factors associated with the risk of hematolymphopoietic malignancies in women. Am J Ind Med 1999; 36: 60-9.

Moller P, knudsen LE, Loft S, Wallin H. The comet assay as a rapid test in biomonitoring occupational exposure to DNA-damaging agents and effect of confounding factors. Cancer Epidemiol Biomarkers Prev 2000; 9(10); 1005-15.

Müller W-U, Nüsse M, Miller BM, Slavotinek A, Viaggi S, Streffer C. Micronuclei: a biological indicato of radiation damage. Mutat Res 1996; 366: 163-169.

Narod SA, Neri L, Risch HA, Raman S. Lymphocyte micronuclei and sister chromatid exchanges among canadian federal laboratory employees. Am J Ind Med $1988 ; 14: 449-56$.

Nilsson R, Nordlinder R, Högstedt B, Karlsson A, Järvholm B. Symptoms, lung and liver function, blood counts, and genotoxic effects in coastal tanker crews. Int Arch Occup Environ Health 1997: 69: 392-8.

Nise G, Hogsted B, Bratt I, Skerfving S. Cytogenetic effects in rotogravure printers exposed to toluene (and benzene). Mutat Res 1991; 261(30: 217-23. 
Ojajarvi IA, Partanen TJ, Ahlbom A, Boffeta P, Hakulinen T, Jourenkova N, kauppinen TP, kogevinas M, Porta M, Vainio HU, Weiderpass E, Wesseling $\mathrm{CH}$. Occupational exposures and pancreatic cancer: a meta-analysis. Occup Environ Med 2000; 57(5): 316-24.

O'Leary LM, Hicks AM, Peters JM, London S. Parental occupational Exposures and Risk of Childhood Cancer: A Review. Am J Ind Med 1991; 20: 17-35.

Olin GR. The hazards of a chemical laboratory environment - a study of the mortality in two cohorts of Swedish chemists. J Am Ind Hyg Assoc 1978; 39(7): 557-62.

Olsen J. Risk of exposure to teratogens amongst laboratory staff and painters. Dan Med Bull 1983; 30: 24-8.

Pesch B, Haerting J, Ranft U, klimpel A, Oelschlagel B, Schill W. Occupational risk factors for renal cell carcinoma: agent-specific results from a case-control study in Germany. Int J Epidemiol 2000, 29(6): 1014-24.

Pinto D. Ceballos JM, Garcia G, Guzman P, Del Razo LM, Vera E, Gomez H, Garcia A, Gonsebatt ME. Increased cytogenetic damage in outdoor painters. Mutat Res 2000; 467(2):105-11.

Pitarque M, Carbonell E, Lapeña N, Marsá M, Torres M, Creus A, Xamena N, Marcos R. No increase in micronuclei frequency in cultured blood lymphocytes from a group of filling station attendants. Mutat Res 1996; 367: 161-7.

Pitarque M, Creus A, Marcos R, Hughes JÁ, Anderson D. Examination of various biomarkers measuring genotoxic endpoints from Barcelona airport personnel. Mutat Res 1999a; 440(2): 195-204. 
Pitarque M, Vaglenov A, Nosko M, Hirvonen A, Norppa H, Creus A, Marcos R.Evaluation of DNA damage by the Comet assay in shoe workers exposed to toluene and other organic solvents. Mutat Res 1999b; 441(1): 115-27.

Pitarque M, Vaglenov A, Nosko M, Pavlova S, Petkova V, Hirvonen A, Creus A, Norppa H, Marcos R. Sister Chromatid Exchanges and Micronuclei in Peripherical Lymphocytes of Shoe Fctory Workers Exposed to Solvents. Environ Health Perspect 2002; 110(4): 399-404.

Pitot HC, Dragan YP. Chemical carcinogenesis. In: Klaassen CD, editor. Casarett \& Doull's Toxicology: the basic science of poisons. $5^{\text {a }}$ ed. New York: McGraw-Hill; 1996.p.201-67.

Rachet B, Partanen T, Kauppinen T, Sasco AJ. Cancer risk in laboratory workers: na emphasis on biological research. Am J Ind Med 2000; 38: 651-65.

Rieger R, Michaelis A, Green MM. A Glossary of Genetics and Cytogenetics. 3. Ed. London: Allen and Unwin, 1968. 507p.

Rojas E, Lopez MC, Valverde M. Single cell gel electrophoresis assay: methodology and applications. J Chromatogr B 1999; 722: 225-54.

Sallmén M, Lindbohm M-L, kyyrönen p, Nykyri E, Anttila A, Taskinen H, Hemminki K. Reduced fertility among women exposed to organic solvents. Am J Ind Med 1995, 27: 699-713.

Savage JRK. Micronuclei: Pitfalls and Problems. In: Atlas of Genetics and Cytogenetics in Oncology and Haematology. July 2000 [www.infobiogen.fr/services/chromcancer/Deep/MicronucleiID20016.html]

Schaumburg I, Olsen J. Congenital malformations and death among the offspring of Danish pharmacy assistants. Am J Ind Med 1990; 18:555-64. 
Silva Augusto LG da, Lieber SR, Ruiz MA, Souza CA de. Micronucleus monitoring to assess human occupational exposure to organochlorides. Environ Mol Mutagen 1997, 29(1): 46-52.

Singh NP, McCoy MT, Tice RR, Schneidr EL. A simple technique for quantification of low levels of DNA damage in individual cell. Exp Cell Res 1988; 175: 184-91.

Snyder R, Andrews LS. Toxic effects of solvents and vapors. In: Klaassen CD, editor. Casarett \& Doull's Toxicology: the basic science of poisons. $5^{\text {a }}$ ed. New York: McGraw-Hill; 1996.p.737-71.

Somorovska M, Szabova E, Vodicka P, Tulinska J, Barancoova M, Fabry R, Liskova A, Riegerova Z, Petrovska H, Kubova J, Rausova K, Dusinska M, Collins A. Biomonitoring of genotoxic risk in workers in a rubber factory: comparison of the Comet assay with cytogenetic methods and immunology. Mutat Res 1999; 445(2) $181-92$.

Sorsa M. Genotoxic Chemicals. In: Encyclopaedia of Occupational Health and Safety. 2000. Cap. 27.

Surrallés J, Natarajan AT. Human lymphocytes micronucleus assay in Europe. Na interanational survey. Mutat Res 1997, 392: 165-74.

Taskinen H, Anttila A, Lindbohm M-L, Sallmén M, Hemmink K. Spontaneous abortions and congenital malformations among the wives of men occupationally exposed to organic solvents. Scand J Work Environ Health 1989; 15: 345-52.

Taskinen H, Kyyrönen P, Hemminki K, Hoikkala M, Lajunen K, lindbohm M-L. Laboratory work and pregnancy outcome. J Occup Med 1994; 36(3): 31 1-9.

Testa A, Ranaldi R, Carpineto L, Pacchierotti F, Tirindelli D, Fabiani L, Giuliani AR, Urso M, Rossini A, Materazzo F, Petyx M, Leoni V. Cytogenetic biomonitoring 
of workers from laboratories of clinical analyses occupationally exposed to chemicals. Mutat Res 2002, 520: 73-82.

Wennborg H, Bodin L, Vainio H, Axelsson G. Pregnancy outcome of personnel in Swedish biomedical research laboratories. J Occup Environ Med 2000, 42(4): 438 46.

Wennborg H, Yuen J, Nise G, Sasco AJ, Vainio H, Gustavsson P. Cancer incidence and work place exposure among Swedish biomedical research personnel. Int Arch Occup Environ Health 2001, 74: 558-64. (A)

Wennborg H, Bodin L, Vainio H, Axelsson G. Solvent use and time to pregnancy among female personnel in biomedical laboratories in Sweden. Occup Environ Med 2001, 58: 225-31. (B)

Wennborg H, Bonde JP, Stenbeck M, Olsen J. Adverse reproduction outcomes among employees working in biomedical research laboratories. Scand J Work Environ Health 2002, 28(1): 5-11.

Windham GC, Shusterman D, Swan SH, Fenster L, Eskenazi B. Exposure to organic solvents and adverse pregnancy outcome. Am J Ind Med 1991; 20: 241-59.

[WHO] World Health Organization. Effects of Occupational Factors on Reproduction. Report on a WHO Meeting; 1983. Apr 25-29, Tbilisi. Copenhagen: WHO; 1985. 


\section{ANEXO I}

Avaliação do Projeto de Tese de Doutorado

pelo Comitê de Ética em Pesquisa (COEP)

da Faculdade de Saúde Pública da Universidade de São Paulo 


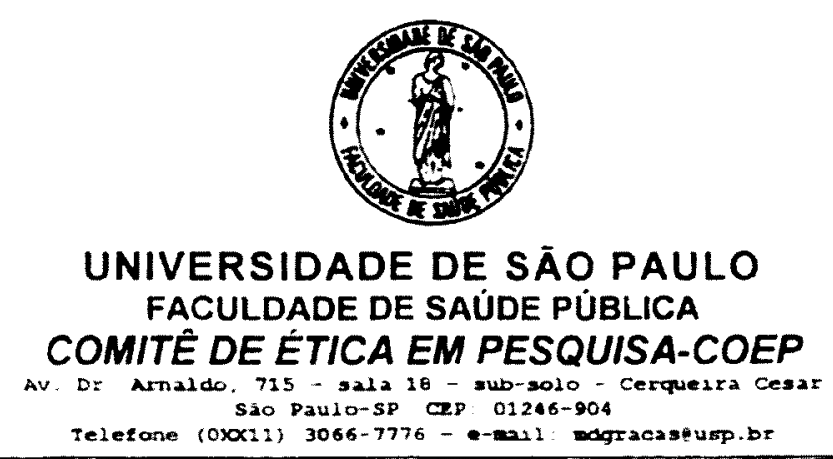

OT.COEP/19/01

14 de fevereiro de 2001

Pelo presente, informo que o Comitè de Etica em Pesquisa da Faculdade de Saude Pública da Universidade de Sào Paulo-COEP, analisou e aprovou, em sua 1 3/00 Sessào Ordinaria, de 130201, de acordo com os requisitos da Resoluçào CNS/196/90, O Protocolo de Pesquisa $n$ " 416, intitulado "EXPOSIÇÃO OCUPACIONAL A SOLVENTES EM TRABALHADORES TECNICOS DE: LABORATORIOS E EFEITOS GENOTOXICOS", apresentado pela pesquisadora Deolinda Krumida Martins.

Atenciosamente.

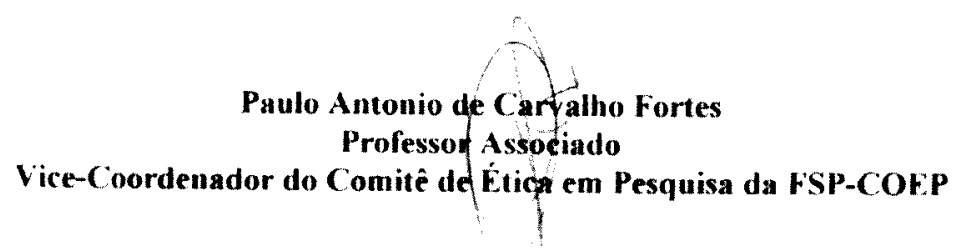




\section{ANEXO II}

Termo de Consentimento Pós-Informado

\section{Grupo Exposto}




\title{
TERMO DE CONSENTIMENTO PÓS-INFORMADO
}

\begin{abstract}
APRESENTAÇÃO
Meu nome é Deolinda, sou aluna do Curso de Pós-Graduação (Doutorado) da Faculdade de Saúde Pública da Universidade de São Paulo e estou conversando com funcionários deste Instituto para verificar se concordam em participar da pesquisa que pretendo realizar como Tese de Doutorado. Para você poder decidir, gostaria de lhe informar o que é e o que pretende este estudo e como será a sua participação.
\end{abstract}

\section{INFORMAÇÕES SOBRE O ESTUDO}

O estudo pretende avaliar a exposição de trabalhadores técnicos de laboratórios a solventes orgânicos, ou seja, verificar quais solventes orgânicos os trabalhadores estão expostos, com que frequiência esta exposição ocorre e em que concentrações estes compostos estão presentes no ambiente de trabalho. Após caracterizar esta exposição, o estudo pretende verificar a possível correlação entre a exposição e o risco de efeitos nocivos à saúde.

Para por em prática tal estudo, serão realizadas 3 tipos de avaliações:

1. Avaliação ambiental: na qual será coletada uma amostra de ar do ambiente de trabalho através de um dispositivo externo colocado próximo à zona respiratória do trabalhador voluntário. A coleta pode durar algumas horas ou até mesmo uma jornada de trabalho (em torno de 6-8 horas).

2. Avaliação biológica: na qual será coletada uma amostra de sangue do trabalhador voluntário para análise em laboratório de indicador biológico de efeito precoce.

3. Aplicação de questionário/entrevista: o qual deverá ser respondido pelo trabalhador voluntário na presença do pesquisador e constará de perguntas relacionadas a: dados e hábitos pessoais, informações sobre as atividades realizadas no trabalho. 


\section{O ESTUDO GARANTE:}

- o anonimato dos participantes, assim os mesmos não serão identificados na redação da Tese ou de trabalhos que vierem a ser publicados;

- o retorno individual dos resultados das análises realizadas, assim como da análise final para a Instituição:

- o direito de desistência de participação no estudo a qualquer momento;

- o fornecimento de esclarecimentos e informações sobre os temas abordados, antes do início e no decorrer do estudo.

\section{COMPROMISSO DO PESQUISADOR:}

Comprometo-me a conduzir todas as atividades deste estudo de acordo com o presente Termo de Consentimento Pós-Informado, colocando-me à disposição para quaisquer esclarecimentos e informações:

Deolinda Izumida Martins

Endereço: Alameda dos Jurupis, 896 apto $47 \mathrm{~A}$

04088-002 - Indianópolis - São Paulo - SP

Fone: $(0 \times x 11)$ 5055-7123/9646-6661

e-mail: izumida@terra.com.br

\section{CONSENTIMENTO PÓS-INFORMADO}

Após ter sido informado sobre o estudo para estimar a exposição a solventes orgânicos e avaliar o risco de efeitos nocivos à saúde entre trabalhadores técnicos de laboratório, concordo em participar deste estudo.

Nome:

Assinatura:

Data: 


\section{ANEXO III}

Termo de Consentimento Pós-Informado

Grupo não-exposto 


\section{TERMO DE CONSENTIMENTO PÓS-INFORMADO}

\section{APRESENTAÇÃO}

Meu nome é Deolinda, sou aluna do Curso de Pós-Graduação (Doutorado) da Faculdade de Saúde Pública da Universidade de São Paulo e estou conversando com funcionários desta Empresa para verificar se concordam em participar da pesquisa que pretendo realizar como Tese de Doutorado. Para você poder decidir, gostaria de lhe informar o que é e o que pretende este estudo e como será a sua participação.

\section{INFORMAÇÕES SOBRE O ESTUDO}

O estudo pretende avaliar a exposição de trabalhadores técnicos de laboratórios a solventes orgânicos e efeitos nocivos à saúde. Mas para que seja validado, precisa de uma População Controle, ou seja, pesssoas que não trabalhem (ou trabalharam) com solventes orgânicos em laboratórios ou outros locais de trabalho, para que seja realizada uma comparação.

Para pôr em prática tal estudo, serão realizados 2 tipos de avaliações:

1. Avaliação biológica: na qual será coletada uma amostra única de sangue (cerca de $5 \mathrm{~mL}$ ) do trabalhador voluntário.

2. Aplicação de questionário/entrevista: o qual deverá ser respondido pelo trabalhador voluntário na presença do pesquisador e constará de perguntas relacionadas a: dados e hábitos pessoais. 


\section{O ESTUDO GARANTE:}

- o anonimato dos participantes, assim os mesmos não serão identificados na redação da Tese ou de trabalhos que vierem a ser publicados;

- o retorno individual dos resultados das análises realizadas, assim como da análise final para a Instituição;

- o direito de desistência de participação no estudo a qualquer momento;

- o fornecimento de esclarecimentos e informações sobre os temas abordados, antes do início e no decorrer do estudo.

\section{COMPROMISSO DO PESQUISADOR:}

Comprometo-me a conduzir todas as atividades deste estudo de acordo com o presente Termo de Consentimento Pós-Informado, colocando-me à disposição para quaisquer esclarecimentos e informações:

Deolinda Izumida Martins

Endereço: Alameda dos Jurupis, 896 apto $47 \mathrm{~A}$

04088-002 - Indianópolis - São Paulo - SP

Fone: $(0 \times x 11)$ 5055-7123/9646-6661

e-mail: izumida@terra.com.br

\section{CONSENTIMENTO PÓS-INFORMADO}

Após ter sido informado, concordo em participar deste estudo.

Nome:

Assinatura: Data: 


\section{ANEXO IV}

Ficha de Coleta

Análise Ambiental

A-9 


\section{FICHA DE COLETA AMBIENTAL}

PESQUISA SOBRE

"EXPOSIÇÃO OCUPACIONAL A SOLVENTES ORGÂNICOS EM

TRABALHADORES DE LABORATÓRIOS E EFEITOS GENOTÓXICOS”

LABORATÓRIO: AMOSTRA $\mathrm{N}^{\circ}$

AGENTE QUÍMICO: DATA:

MEIO DE CAPTAÇÃO:

\section{DADOS da COLETA da AMOSTRA}

PERÍODO(S) de COLETA: inicial: $h$; final: $\mathrm{h}$

inical: $\mathrm{h}$; final: $\mathrm{h}$ inical: $h$; final: $\mathrm{h}$

TOTAL da COLETA: $\mathrm{h}$ $\min$ ATIVIDADES:

CONDIÇÕES AMBIENTAIS e do TRABALHO

TEMPERATURA: inicial: ${ }^{\circ} \mathrm{C}$; final: ${ }^{\circ} \mathrm{C}$

VENTILAÇÃO:

RITMO: ( ) normal ( ) aumentado ( ) reduzido HORÁRIO DE TRABALHO:

INTERRUPÇÕES: HORÁRIO DE REFEIÇÃO: 


\section{ANEXO V}

Questionário

Avaliação Ambiental

A-11 
UNIVERSIDADE DE SÃO PAULO

FACULDADE DE SAÚDE PÚBLICA

DEPARTAMENTO DE SAÚDE AMBIENTAL

PESQUISA SOBRE "EXPOSIÇÃO OCUPACIONAL A SOLVENTES

ORGÂNICOS EM TRABALHADORES DE LABORATÓRIOS E EFEITOS

GENOTÓXICOS"

QUESTIONÁRIO/ENTREVISTA

Número de identificação $\left.\left.\left.\right|_{-}\right|_{-}\left|-I_{-}\right|_{-}\right|_{-} \mid$

Nome do participante

Endereço

Telefone 


\section{INFORMAÇÕES GERAIS}

A1 Data da entrevista. horas

A2 Início da entrevista.

A3 Sexo (1) Masculino (2) Feminino.

A4 Raça: (1) Branco (2) Mulato (3) Negro (4) Índio (5) Oriental. .1

A5 Idade / anos completos

A6 Data de nascimento

A7 Em que Cidade/Estado você nasceu ?

A8 Há quantos anos reside na região metropolitana de São Paulo ? I I anos A9 Se está vivendo há menos de 1 ano em São Paulo, onde morava antes?

A10 Escolaridade: /
(1) I grau incompleto
(4) II grau completo
(7) especialização
(2) I grau completo
(5) III grau incompleto
(8) mestrado
(3) II grau incompleto
(6) III grau completo
(9) doutorado
A11 Estado civil: /
(1) solteiro
(3) vivendo junto
(5) viúvo
(2) casado
(4) separado (desquitado/divorciado) 


\section{QUESTÕES OCUPACIONAIS}

B1 Qual o seu cargo?

B2 Tempo de trabalho nesta função $/$ anos $/$ _ $/$ meses

B3 Tempo de trabalho neste Instituto. / anos $/$ /meses

B4 Liste todos os trabalhos anteriores ao atual, partindo do mais recente (excluindo $o$ atual) para o mais antigo, especificando a função/atividade e o tempo em cada um deles:

Ocupação/função

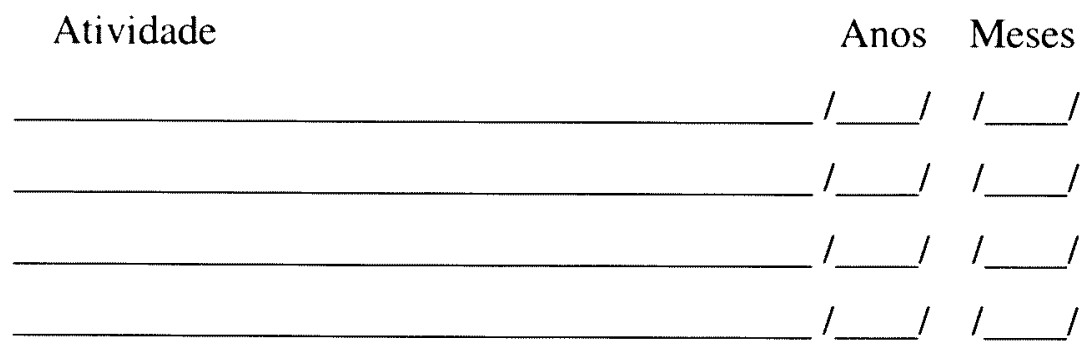

B5 Qual seu horário de trabalho? (1)integral (2)meio período (3)outro/especificar........./

B6 Qual sua jornada de trabalho diária ? / horas

B7 Qual sua jornada de trabalho semanal ? / horas

B8 Em média qual o tempo gasto para ir do domicílio ao local de trabalho (ida e volta) ?/ /horas / / minutos

B9 Meios de transporte para o trabalho.

(1) a pé

(3) transporte coletivo-ônibus

(5) outros

(2) transporte próprio

(4) transporte coletivo-trem/metrô

B10 Você poderia descrever suas atividades neste laboratório e o tempo gasto em cada uma delas?

\begin{tabular}{l} 
Atividade \\
1 \\
2 \\
3 \\
4 \\
5 \\
\hline
\end{tabular}

Tempo (h/dia ou h/sem) 
B11 Em quais atividades acima você manipula solventes orgânicos ?

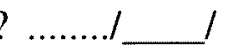

B12 Quais dos seguintes solventes orgânicos são utilizados ?

- Éter

- Clorofórmio

Sim

Não

Não sabe

- Metanol

- Etanol

- Acetonitrila

- Acetato de Etila

- Acetona

- Hexano

- Ciclohexano

- Isooctano

- Diclorometano

- Tolueno

- Isopropanol

- Tetrahidrofurano (THF)

- Outros:
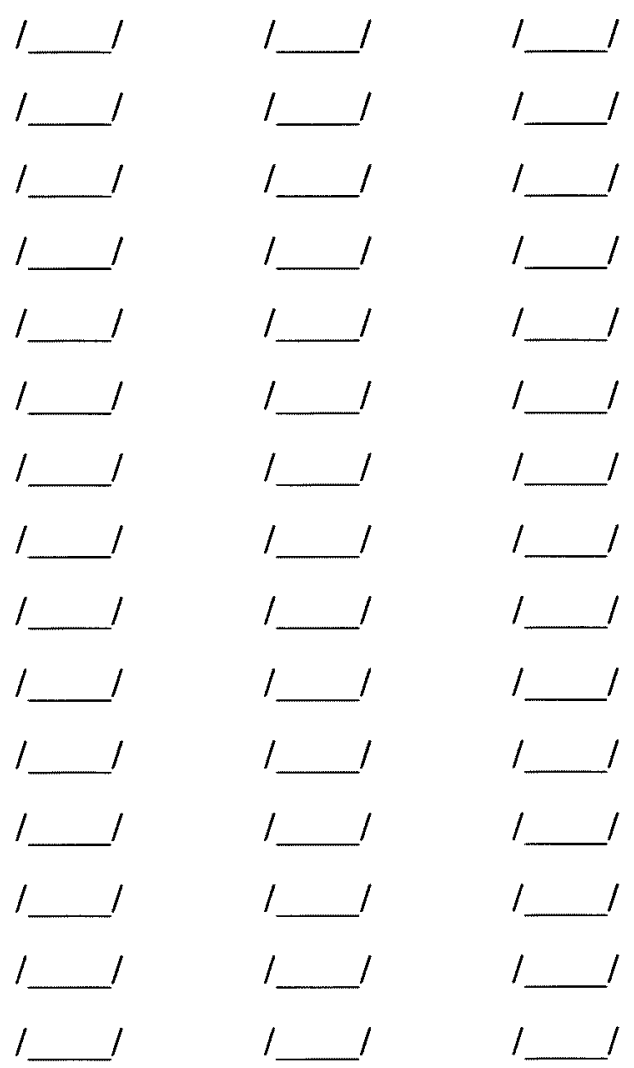

B13 Que outros produtos químicos são manipulados em suas atividades de trabalho?

B14 Término da entrevista. horas 
ANEXO VI

Questionário

Avaliação Biológica

A-16 
UNIVERSIDADE DE SÃO PAULO

FACULDADE DE SAÚDE PÚBLICA

DEPARTAMENTO DE SAÚDE AMBIENTAL

PESQUISA SOBRE "EXPOSIÇÃO OCUPACIONAL A SOLVENTES ORGÂNICOS EM TRABALHADORES DE LABORATÓRIOS E EFEITOS GENOTÓXICOS"

QUESTIONÁRIO/ENTREVISTA

\section{QUESTIONÁRIO - PROJETO TRABALHADORES TÉCNICOS DE LABORATÓRIOS}

Data:

Nome:

Data de nascimento: 1 Local de Nascimento:

Endereço: n. $.^{\circ}:$ apto:

Bairro: Cidade:

Estado: CEP:

Telefone: ( ) 


\section{INFORMAÇÕES GERAIS}

A1 (1) Exposto (2) Não-exposto.

A2 Iniciais (sobrenome-nome)

B1 Data da entrevista

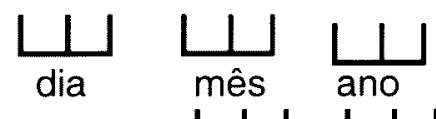

B2 Início da entrevista

B3 Qual é a sua idade (anos completos)?

B4 Você freqüentou a escola? ( 1 ) sim ( 2 ) não Se não, vá para $\mathbf{C} 1$.

B5 Qual o seu grau de escolaridade?

$\begin{array}{ll}\text { ( ) fundamental } & (\text { ) completo } \\ \text { ( ) médio } & (\text { ) incompleto }\end{array}$

\section{HÁBITO DE FUMAR}

C1 Você fuma ou fumou em média 1 cigarro ou charuto ou cachimbo, diariamente, pelo menos por 1 ano?
( 1 ) sim, ainda fuma
( 2 ) nunca fumou
( 3 ) somente no passado

(Se parou nos últimos 12 meses, assinalar ( 1 ))

(Se nunca fumou, vá para $\mathbf{C 5}$ )

Por favor. descreva os períodos de sua vida em que você fumou cigarro. charuto ou cachimbo, as quantidades que fumou e outros detalhes sobre o fumo.

C2 Você fuma ou já fumou "cigarro"? (Se não, vá para C3)

\begin{tabular}{c|c|c|c|c|c}
\hline $\begin{array}{c}\text { Cigarro } \\
\text { (a) }\end{array}$ & $\begin{array}{c}\text { Idade de } \\
\text { início }\end{array}$ & $\begin{array}{c}\text { Idade que } \\
\text { parou }\end{array}$ & $\begin{array}{c}\text { Tipo de } \\
\text { cigarro (b) }\end{array}$ & Marca & N. por dia \\
\hline & & & & & \\
\hline
\end{tabular}

(a) (1) $\operatorname{sim}$ (2) não

(b) (1) manufaturado, com filtro (2) manufaturado, sem filtro
(3) enroladinho de papel
(4) enroladinho de palha
( 5 ) não sabe

C3 Você fuma ou já fumou charuto? (Se não, vá para C4)

\begin{tabular}{c|c|c|c|c}
\hline $\begin{array}{c}\text { Charuto } \\
\text { (a) }\end{array}$ & Idade de inicio & Idade que parou & Marca & N. ${ }^{\circ}$ por dia \\
\hline & & & & \\
\hline
\end{tabular}

(a) (1) $\operatorname{sim} \quad$ (2) não 
C4 Você fuma ou já fumou cachimbo? (Se não, vá para C5)

\begin{tabular}{c|c|c|c|c|}
\hline $\begin{array}{c}\text { Cachimbo } \\
\text { (a) }\end{array}$ & $\begin{array}{c}\text { Idade de } \\
\text { inicio }\end{array}$ & $\begin{array}{c}\text { Idade que } \\
\text { parou }\end{array}$ & Marca & $\begin{array}{c}\text { N. }{ }^{\circ} \text { de vezes que enche } \\
\text { cachimbo por dia }\end{array}$ \\
\hline & & &
\end{tabular}

(a) (1) sim (2) não

C5 Você fuma ou já fumou maconha (marijuana), pelo menos uma vez por semana e pelo menos por 6 meses? (Se não, vá para $\mathbf{C 6}$ )

\begin{tabular}{c|c|c|c}
\hline Maconha & Idade de início & Idade que parou & $\begin{array}{c}\text { N. }{ }^{\circ} \text { de vezes por } \\
\text { semana }\end{array}$ \\
\hline
\end{tabular}

(a) (1) sim (2) não

\section{AS QUESTÕES C6-C9 SÃO PARA NÃO FUMANTES}

C6 Você esteve casado(a) (ou vivendo junto) com um fumante?
(1) $\operatorname{sim}$
( 2 ) não
(Se não, vá para C8)

C7 Descreva o hábito do fumo do seu companheiro na sua presença:

\begin{tabular}{|c|c|c|c|}
\hline \multirow{2}{*}{$\begin{array}{c}\text { Sua idade quando } \\
\text { o companheiro(a) } \\
\text { iniciou }\end{array}$} & \multirow{2}{*}{$\begin{array}{c}\text { Sua idade quando } \\
\text { o companheiro(a) } \\
\text { parou }\end{array}$} & \multicolumn{2}{|c|}{ N. ${ }^{\circ}$ de horas/dia que fumava na sua presença } \\
\hline & & Durante a semana & $\begin{array}{l}\text { Fim de } \\
\text { semana }\end{array}$ \\
\hline & & & \\
\hline
\end{tabular}

C8 Você trabalha(ou) em lugar fechado onde as pessoas fumassem?
(1) $\operatorname{sim}$
( 2 ) não
(Se não, vá para D1)

C9 Descreva os períodos durante os quais você trabalhou com fumantes:

\begin{tabular}{c|c|c|c|}
\hline $\begin{array}{c}\text { Sua idade quando } \\
\text { iniciou }\end{array}$ & $\begin{array}{c}\text { Sua idade quando } \\
\text { parou }\end{array}$ & $\begin{array}{c}\text { N.* de horas/dia que } \\
\text { estava exposto }\end{array}$ & Nivel de fumaça* \\
\hline & & & \\
\hline
\end{tabular}

*(1) muito (2) pouco (3) não lembra

\section{HÁBITOS ALIMENTARES}

Assinalar a opção de freqüência mais apropriada.

\begin{tabular}{|l|l|l|l}
\hline \multicolumn{1}{|c|}{ Porção } & \multicolumn{1}{c}{ Alimento } & Freqüência \\
\hline D1 & 1 copo $(200 \mathrm{ml})$ & Leite & \\
\hline D2 & 1 pote $(125 \mathrm{~g})$ & logurte & \\
\hline D3 & $1 \mathrm{c}$. de chá & Manteiga & \\
\hline D4 & $50 \mathrm{~g}$ ou 1 pãozinho & Pão & \\
\hline D5 & 4 c. de sopa cheias & Macarrão ou arroz & \\
\hline D6 & $100 \mathrm{~g}$ ou 1 prato fundo cheio & Pratos a base de milho (polenta ...) & \\
\hline D7 & 1 pedaço médio & Mandioca, Aipim & \\
\hline D8 & $40 \mathrm{~g}$ ou 4 c. sopa cheias & Farinha de mandioca & \\
\hline D9 & $80 \mathrm{~g}$ ou 1 pedaço médio & Carne de boi & \\
\hline D10 & $100 \mathrm{~g}$ ou 1 pedaço médio & Carne de porco & \\
\hline D11 & $160 \mathrm{~g}$ ou 1 pedaço médio & Galinha ou frango & \\
\hline
\end{tabular}




\begin{tabular}{|l|l|l|l}
\hline D12 & $80 \mathrm{~g}$ ou 1 pedaço médio & Outras carnes (carneiro etc.) & \\
\hline D13 & $150 \mathrm{~g}$ ou 1 pedaço médio & Peixe & \\
\hline D14 & $\begin{array}{l}\text { 2 fatias presunto; 4 de } \\
\text { salame; } 2 \text { salsichas }\end{array}$ & Presunto, salame, salsicha & \\
\hline D15 & 1 unidade & Ovo & \\
\hline D16 & $50 \mathrm{~g}$ ou 2 fatias médias & Queijo & \\
\hline D17 & 1 unidade média & Batata & \\
\hline D18 & $50 \mathrm{~g}$ ou 1 prato de sobremesa & Vegetais crus e salada & \\
\hline D19 & 50 gu 1 prato de sobremesa & $\begin{array}{l}\text { Brócolis, repolho, couve de } \\
\text { Bruxelas }\end{array}$ & \\
\hline D20 & 1 média & Cenoura & \\
\hline D21 & 1 pequeno & Tomate & \\
\hline D22 & 4 c. sopa cheias & Grãos: feijão, lentilha, ervilha & \\
\hline D23 & 50 g ou 1 prato de sobremesa & $\begin{array}{l}\text { Em resumo: quantas vezes come } \\
\text { uma porção de qualquer tipo de } \\
\text { vegetal por semana, exceto } \\
\text { batata? }\end{array}$ & \\
& & Suco de frutas & \\
\hline D24 & 1 copo ou 200ml & Maçã ou pêra & \\
\hline D25 & 1 média & Frutas cítricas (laranja, lima...) & \\
\hline D26 & 1 média & Banana & \\
\hline D27 & 1 média & $\begin{array}{l}\text { Em resumo: quantas vezes come } \\
\text { qualquer fruta fresca por semana? }\end{array}$ & \\
\hline D28 & 1 média & Bolo ou doces(sobremesas) & \\
\hline D29 & 1 fatia ou taça &
\end{tabular}

Qual o tipo de gordura que você "mais usa":

D30 Para temperar os vegetais?.

D31 Para cozinhar?
(1) azeite de oliva
(2) azeite dendê
( 6 ) não usa gordura
( 7 ) óleo de uva
( 8 ) óleo milho
(9) girassol
( 10 ) óleo de soja
(11) outro óleo de semente
(12) banha de porco
(13) outra gordura
(4) manteiga
( 5 ) margarina
(99) não sabe

D32 Nos últimos dois anos o(a) Sr.(a) tem tomado vitaminas (remédios)?.
(1) $\operatorname{sim}(2)$ não ( 9 ) não sabe
Se não, pule para E1

D33 Com que freqüência o(a) $\mathrm{Sr}$,(a) toma estas vitaminas?.
(1) Diariamente
(4) Ocasionalmente
( 2 ) Uma vez por semana
( 3 ) Uma vez por mês
(5) Nunca

\section{HÁBITOS DE BEBIDAS}

E1 Você bebe ou bebeu bebidas de álcool pelo menos 1 vez por mês?.
(1) sim, ainda bebe
( 2 ) nunca
( 3 ) só no passado
(Se parou nos últimos 12 meses, a resposta é ( 1 ) sim, ainda bebe)
(Se nunca, pule para E7)

Descreva os periodos de sua vida durante os quais você tomou bebidas alcoólicas 
Unidade ( a )

(1) Copo pequeno $-50 \mathrm{~mL}$

( 2 ) Copo médio $-100 \mathrm{~mL}$

( 3 ) Copo grande $-250 \mathrm{~mL}$

(4) $1 / 2$ ou pequena garrafa $-330 \mathrm{~mL}$

( 5 ) Garrafa - 700-750mL

(6) Garrafa - 1L
Por (b)

(1) Dia

(2) Semana

( 3 ) Mês

\begin{tabular}{|c|c|c|c|c|c|}
\hline Cerveja & $\begin{array}{l}\text { Idade de } \\
\text { início }\end{array}$ & $\begin{array}{l}\text { Idade que } \\
\text { parou }\end{array}$ & $\begin{array}{c}\text { Unidade } \\
\text { (a) }\end{array}$ & $\begin{array}{c}\text { Quantas unidades } \\
\text { consome }\end{array}$ & Por (b) \\
\hline Vinho & $\begin{array}{l}\text { Idade de } \\
\text { início }\end{array}$ & $\begin{array}{c}\text { Idade que } \\
\text { parou }\end{array}$ & $\begin{array}{c}\text { Unidade } \\
\text { (a) }\end{array}$ & $\begin{array}{c}\text { Quantas unidades } \\
\text { consome }\end{array}$ & Por (b) \\
\hline $\begin{array}{c}\text { Aperitivo } \\
\text { (cachaça, } \\
\text { uísque, vodca, } \\
\text { rum, etc.) }\left(>35^{\circ}\right)\end{array}$ & $\begin{array}{l}\text { Idade de } \\
\text { inicio }\end{array}$ & $\begin{array}{c}\text { Idade que } \\
\text { parou }\end{array}$ & $\begin{array}{c}\text { Unidade } \\
\text { ( a ) }\end{array}$ & $\begin{array}{c}\text { Quantas unidades } \\
\text { consome }\end{array}$ & Por (b) \\
\hline $\begin{array}{l}\text { Licores } \\
\left(<35^{\circ}\right)\end{array}$ & $\begin{array}{l}\text { Idade de } \\
\text { início }\end{array}$ & $\begin{array}{l}\text { Idade que } \\
\text { parou }\end{array}$ & $\begin{array}{c}\text { Unidade } \\
\text { (a) }\end{array}$ & $\begin{array}{c}\text { Quantas unidades } \\
\text { consome }\end{array}$ & Por (b) \\
\hline
\end{tabular}

E6 Você toma ou tomava chimarrão habitualmente ?

(1) sim, ainda (2) nunca ( 3 ) só no passado

(Se parou nos últimos 12 meses, a resposta é ( 1 ) sim, ainda toma)

(Se nunca, pule para F1)

Descreva os periodos de sua vida durante os quais você consumia mate.

\begin{tabular}{|c|c|c|}
\hline Idade de início & Idade que parou & $\begin{array}{l}\text { Quantidade de água por dia } \\
\text { ( mililitros }-\mathbf{m} L)\end{array}$ \\
\hline erate & você costuma ou & a tomar o mate? \\
\hline
\end{tabular}

\section{HISTÓRICO FAMILIAR}

F1 Você já esteve casado(a) ou vivendo junto com alguém?
(1) sim
( 2 ) não

F2 No total, quantos filhos você teve?

F3 Filhos vivos: quantidade/sexo

F4 Filhos mortos: quantidade/sexo Causa da morte :

F5 Teve filhos com malformações congênitas? ( ) sim ( ) não Tipo:

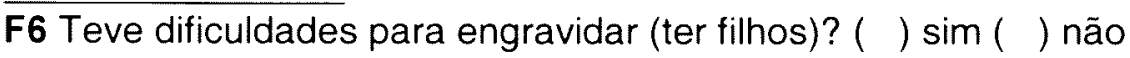


F7 Casos de câncer na família: $($ ) sim

não

\begin{tabular}{l|c|c}
\hline & Grau de parentesco & Tipo de Câncer \\
\hline 01 & & \\
\hline 02 & & \\
\hline
\end{tabular}

Grau de parentesco:
(1) mãe
( 3 ) irmã
( 5 ) filha
( 7 ) companheiro (a)
(2) pai
(4) irmão
(6) filho
( 8 ) próprio(a)
individuo

\section{SAÚDE / MEDICAMENTOS}

G1 Procurou atendimento médico nos últimos 15 dias?
(1) não
(2) sim, por problemas de saúde
(3) sim, para exame periódico

G2 Está usando algum medicamento ? (1) sim (2) não.

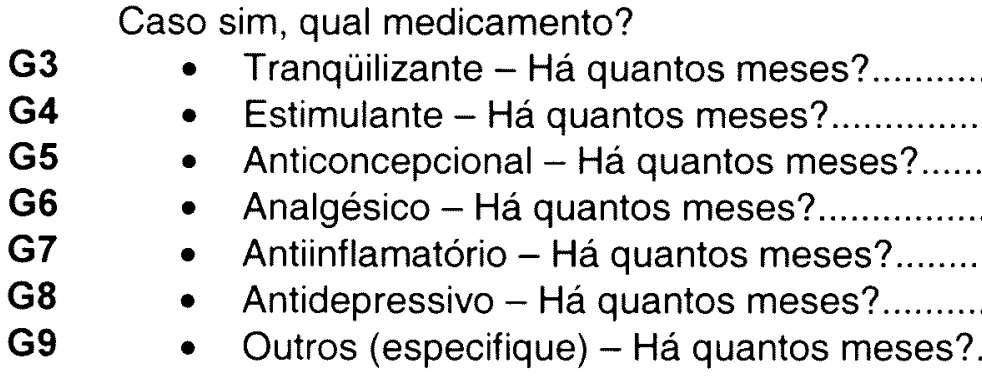

\section{SOMENTE PARA MULHERES}

H1 Faz ou fez uso de contraceptivo?

( ) $\operatorname{Sim}($ ) Não

H2 Faz ou fez uso de reposição hormonal?

( ) $\operatorname{Sim}($ ) Não

Término da entrevista:

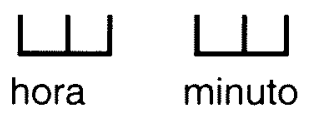

Comentários: 